Eduardo Augusto Machado

Avaliação de desempenho em sustentabilidade de grupos multissetoriais: proposição de um modelo conceitual para seleção de indicadores e métricas

Dissertação de Mestrado

Dissertação apresentada como requisito parcial para obtenção do grau de Mestre pelo Programa de Pós-Graduação em Metrologia (Área de concentração: Metrologia para Qualidade e Inovação) da PUC-Rio.

Orientadora: Prof. ${ }^{a}$ Maria Fatima Ludovico de Almeida

Rio de Janeiro

Abril de 2018 
Eduardo Augusto Machado

\section{Avaliação de desempenho em sustentabilidade de grupos multissetoriais: proposição de um modelo conceitual para seleção de indicadores e métricas}

Dissertação apresentada como requisito parcial para obtenção do grau de Mestre pelo Programa de Pós-Graduação em Metrologia (Área de concentração: Metrologia para Qualidade e Inovação) da PUC-Rio. Aprovada pela Comissão Examinadora abaixo assinada.

Prof. ${ }^{a}$ Maria Fatima Ludovico de Almeida

Orientadora

Programa de Pós-Graduação em Metrologia - PUC-Rio

Prof. Carlos Augusto Caldas de Moraes Universidade Candido Mendes - UCAM

Prof. Carlos Roberto Hall Barbosa Programa de Pós-Graduação em Metrologia - PUC-Rio

Prof. Márcio da Silveira Carvalho Coordenador Setorial do Centro Técnico Científico - PUC-Rio

Rio de Janeiro, 27 de abril de 2018 
Todos os direitos reservados. É proibida a reprodução total ou parcial do trabalho sem autorização da universidade, da autora e de sua orientadora.

\section{Eduardo Augusto Machado}

Graduado em Administração e Pós-graduado em Marketing pela Pontifícia Universidade Católica do Rio de Janeiro (PUC-Rio). MBA Executivo pela Coppead da Universidade Federal do Rio de Janeiro (UFRJ). Empresário com experiência profissional em gestão e projetos especiais na área da teleinformática. Atualmente é mestrando do Programa de Pós-Graduação em Metrologia da PUC-Rio.

Ficha Catalográfica

Machado, Eduardo Augusto

Avaliação de desempenho em sustentabilidade de grupos multissetoriais: proposição de um modelo conceitual para seleção de indicadores e métricas / Eduardo Augusto Machado ; orientadora: Maria Fatima Ludovico de Almeida. - 2018.

146 f. ; $30 \mathrm{~cm}$

Dissertação (mestrado)-Pontifícia Universidade Católica do Rio de Janeiro, Centro Técnico Científico, Programa de Pós-Graduação em Metrologia para a Qualidade e Inovação, 2018.

Inclui bibliografia

1. Metrologia - Teses. 2. Avaliação de desempenho. 3. Indicadores e métricas. 4. Grupos multissetoriais. 5. Sustentabilidade corporativa. 6. Métodos multicritério de apoio à decisão. I. Almeida, Maria Fatima Ludovico de. II. Pontifícia Universidade Católica do Rio de Janeiro. Centro Técnico Científico. Programa de Pós-Graduação em Metrologia para a Qualidade e Inovação. III. Título.

CDD: 389.1 


\section{Agradecimentos}

À minha esposa Silvia, você é a razão do meu mestrado pois, muito mais que minha incentivadora, foi quem transformou minha vontade em realização. $\mathrm{Na}$ realidade você é o pilar fundamental da nossa unidade familiar.

Aos meus filhos Luis Eduardo, Maria Eduarda, Carlos Eduardo e Marianna, e à minha neta Maria Luisa, que veio no decorrer do mestrado. Meu muito obrigado pelo orgulho que emana de vocês! Tenham certeza que apesar da rigidez, é recíproco. Vocês me motivaram muito durante todo esse processo.

Aos meus Pais, meu agradecimento pela base que me permitiu avançar no sentido do cumprimento exitoso desta marcante etapa acadêmica.

À minha orientadora Professora Doutora Maria Fatima Ludovico de Almeida, pela competência e humildade na transmissão irrestrita de conhecimentos fundamentais, diferenciados e valiosos. Aprendi e me desenvolvi pessoal e academicamente. Saio sem dúvida muito melhor do que entrei. Em grande parte, graças à pessoa que você é, tenho absoluta convicção disso.

A todos os membros da Comissão Examinadora pelas contribuições, que muito enriqueceram a versão final da dissertação.

Meu agradecimento especial ao Coordenador Professor Doutor Carlos Roberto Hall Barbosa, um estímulo desde o primeiro contato ao explicar claramente a importância da metrologia para o mundo.

Aos funcionários, colaboradores e professores do Programa de Pósgraduação em Metrologia da PUC-Rio que em todas as oportunidades agregaram valor e conhecimento, tendo colaborado para meu melhor desempenho.

À Capes e à PUC-Rio pelo apoio concedido durante esse período de pesquisa.

Ao Grupo Algar pela abertura para acesso irrestrito para realização do estudo empírico e disponibilidade da alta liderança e gestores do Grupo para participação das reuniões de aplicação do modelo conceitual no nível corporativo. 


\section{Resumo}

Machado, Eduardo Augusto; Almeida, Maria Fatima Ludovico de. Avaliação de desempenho em sustentabilidade de grupos multissetoriais: proposição de um modelo conceitual para seleção de indicadores e métricas. Rio de Janeiro, 2018. 146 p. Dissertação de Mestrado - Programa de Pós-Graduação em Metrologia, Pontifícia Universidade Católica do Rio de Janeiro.

Grupos multissetoriais e empresas holdings atuam em ambientes cada vez mais dinâmicos e complexos, com exigências e preocupações crescentes para atingir patamares superiores de sustentabilidade. Atualmente, as Diretrizes G4 da Global Reporting Initiative (GRI), que são as mais utilizadas mundialmente pelas organizações para elaboração de seus relatórios de sustentabilidade, não apresentam suplementos orientativos específicos para grupos multissetoriais. Nesse contexto, esta dissertação tem por objetivo propor um modelo para a avaliação de desempenho em sustentabilidade de grupos empresariais multissetoriais, mediante a integração das Diretrizes G4 da GRI à ferramenta Balanced Scorecard, com uso de métodos multicritério de apoio à decisão. A pesquisa pode ser considerada descritiva, metodológica e aplicada. A partir dos resultados da revisão bibliográfica e documental sobre os temas centrais da pesquisa, desenvolveu-se um modelo conceitual para avaliação de desempenho em sustentabilidade de grupos empresariais multissetoriais, buscando-se preencher lacunas identificadas na literatura especializada, cobrindo-se o período de 1988 a 2018. A aplicabilidade do modelo conceitual proposto foi demonstrada mediante um estudo empírico no Grupo Algar, que atua nos setores de telecomunicações, agroindústria, serviços e turismo. Os resultados desta pesquisa poderão ser replicados em processos de avaliação de desempenho em sustentabilidade de outros grupos multissetoriais no Brasil e no exterior. No âmbito da GRI, poderão contribuir para a elaboração de um suplemento orientativo para grupos multissetoriais, i.e., G4 Multisectoral Disclosures.

\section{Palavras-chave}

Metrologia; avaliação de desempenho; indicadores e métricas; grupos multissetoriais; sustentabilidade corporativa; métodos multicritério de apoio à decisão. 


\section{Abstract}

Machado, Eduardo Augusto; Almeida, Maria Fatima Ludovico de (Advisor). Sustainability performance assessment of multisectoral groups: a proposal of a conceptual model for selecting indicators and metrics. Rio de Janeiro, 2018. 146 p. Dissertação de Mestrado - Programa de PósGraduação em Metrologia. Pontifícia Universidade Católica do Rio de Janeiro.

Multisectoral groups and holding companies have been operating in dynamic and complex business environments, with increasing concerns to reach higher levels of sustainability. On the other hand, the G4 Guidelines published by the Global Reporting Initiative (GRI), which are the most widely used organizations worldwide for the preparation of their sustainability reports, do not provide guidance supplements for multisectoral groups. In this context, this dissertation aims to propose a model for the sustainability performance assessment of multisectoral business groups by integrating the GRI G4 Guidelines with the Balanced Scorecard tool, with support of multicriteria decision making methods. The research can be considered descriptive, methodological and applied. Based on the results of the bibliographic and documentary review on the central themes of this research, a conceptual model was developed for assessing the sustainability performance of multisectoral groups (MSGs), aiming to fill gaps identified during the literature review and documentary analysis covering the period 1988-2018. The applicability of the model could be demonstrated through an empirical study in the Algar Group, which operates in ICT, agribusiness, tourism and services sectors. The results of this research can be replicated in processes of sustainability performance assessment of other multisectoral groups in Brazil and abroad. Within the scope of the GRI methodology, they can contribute to the formulation of a guidance supplement addressed to multisectoral groups, i.e. the G4 Multisector Disclosures.

\section{Keywords}

Metrology; performance assessment; indicators and metrics; multisectoral groups; corporate sustainability; multi-criteria decision making methods. 


\section{Sumário}

1. Introdução........................................................................... 15

1.1 Definição do problema de pesquisa................................................... 16

1.2 Objetivos: geral e específicos.......................................................... 17

1.3 Motivação..................................................................................... 18

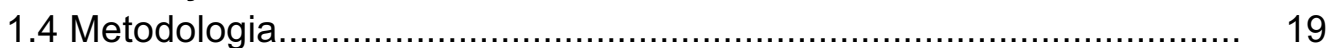

1.4.1 Fase exploratória e descritiva.................................................. 19

1.4.2 Fase de pesquisa aplicada................................................... 21

1.4.3 Fase conclusiva..................................................................... 23

1.5 Estrutura da dissertação............................................................. 23

2. Monitoramento e avaliação de desempenho em sustentabilidade.. 25

2.1 Conceitos básicos.......................................................................... 25

2.1.1 Grupos multissetoriais...................................................... 25

2.1.2 Sustentabilidade corporativa e responsabilidade social empresarial 26

2.1.3 Avaliação de desempenho em sustentabilidade............................. 28

2.2 Abordagens metodológicas para monitoramento e avaliação de desempenho em sustentabilidade..................................................... 30

2.2.1 Balanced Scorecard sustentável................................................ 30

2.2.2 McKinsey Survey on Sustainability........................................... 32

2.2.3 Norma ABNT NBR ISO 9004:2010...................................... 34

2.2.4 Indicadores Ethos para negócios sustentáveis e responsáveis........ 37

2.2.5 Guia da Confederação Nacional da Indústria $(\mathrm{CNI})$ para Estratégias de Baixo Carbono.................................................................................. 38

2.3 Importância da construção da matriz de materialidade com engajamento dos principais stakeholders............................................ 39

2.4 Potencial de aplicação de métodos multicritério para hierarquização e seleção de indicadores de sustentabilidade ......................................... 42

2.5 Considerações finais sobre o capítulo............................................. 44

3. Sistemas de mensuração da sustentabilidade corporativa: índices, indicadores e métricas....................................................... 47

3.1 Diretrizes G4 da Global Reporting Initiative (GRI)........................ 47

3.2 Carbon Disclosure Project (CDP)................................................ 51

3.3 GHG Protocol.......................................................................... 52

3.4 UN Global Compact................................................................ 53

3.5 Índice Dow Jones........................................................................ 54

3.6 Índice Carbono Eficiente (ICO2) ................................................ 56

3.7 Índice de Sustentabilidade Empresarial (ISE)................................ 58

3.8 Quadro comparativo dos sistemas de mensuração da sustentabilidade

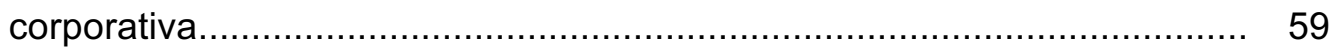

3.9 Implicações para avaliação de desempenho em sustentabilidade no contexto de grupos multissetoriais. 
4. Modelo conceitual para avaliação de desempenho em sustentabilidade de grupos multissetoriais..

4.1 Características e diferenciais do modelo conceitual......................... 65

4.1.1 Uso de critérios e ferramentas da teoria dos stakeholders para a construção da matriz de materialidade de grupos multissetoriais.

4.1.2 Integração da estrutura de indicadores GRI à ferramenta Balanced Scorecard (BSC) para gerenciamento estratégico da sustentabilidade.

4.1.3 Integração de um método híbrido multicritério ao modelo: método AHP- TOPSIS.

4.1.4 Definição de metas de sustentabilidade de curto, médio e longo prazo, alinhadas à visão de futuro do grupo multissetorial....................... 70

4.2 Visão geral do modelo.................................................................... 70

4.3 Visão detalhada de aplicação do modelo.......................................... 72

4.3.1 Etapa 1: Definição dos stakeholders do grupo multissetorial............ 72

4.3.2 Etapa 2: Construção da matriz de materialidade com uso do método AHP: seleção de aspectos materiais por categoria da

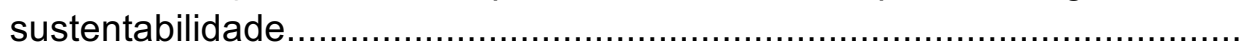

4.3.3 Etapa 3: Definição da estrutura hierárquica para seleção dos indicadores GRI: integração à ferramenta BSC por categoria da sustentabilidade.

4.3.4 Etapa 4: Seleção dos indicadores GRI 'candidatos' por categoria da sustentabilidade: uso do método AHP-TOPSIS.

4.3.5 Etapa 5: Elaboração das identidades dos indicadores selecionados e respectivas métricas......

4.4 Subsídios para elaboração de um suplemento orientativo para grupos multissetoriais pela GRI - G4 Multisectoral Disclosures.

5. Demonstração da aplicabilidade do modelo no âmbito do Grupo Algar.

5.1 Definição das questões e proposições do estudo empírico

5.2 Delimitação e caracterização da unidade de análise e seu contexto organizacional.

5.2.1 Unidade de análise.

5.2.2 Contexto organizacional: o Grupo Algar.................................... 92

5.3 Coleta e formatação de dados.

5.4 Apresentação e discussão dos resultados da aplicação no nível corporativo multissetorial.

5.4.1 Etapa 1: Definição dos stakeholders do grupo multissetorial................

5.4.2 Etapa 2: Construção da matriz de materialidade com uso do método AHP: seleção de aspectos para a categoria 'Ambiental'......

5.4.3 Etapa 3: Definição da estrutura hierárquica para seleção dos indicadores de desempenho: integração da estrutura de indicadores GRI à metodologia Balanced Scorecard...

5.4.4 Etapa 4: Seleção de indicadores por categoria da sustentabilidade com uso do método AHP-TOPSIS.

5.4.5 Etapa 5: Elaboração das identidades dos indicadores selecionados e respectivas métricas. 
6. Conclusões .................................................................................. 114

Referências bibliográficas....................................................... 117

Anexo 1 - Indicadores de sustentabilidade conforme Diretrizes G4 da

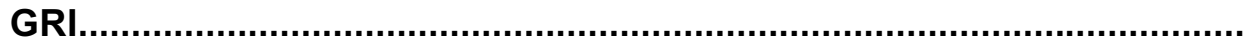

Apêndice 1 - Métodos multicritério de apoio à decisão adotados na pesquisa.

Apêndice 2 - Roteiro e registros das entrevistas no Grupo Algar.....

138

Apêndice 3 - Agendas das reuniões com o Grupo Algar para aplicação do modelo proposto. 


\section{Lista de Figuras}

Figura 1.1 - Desenho da pesquisa, seus componentes e métodos....... 20

Figura 1.2 - Mapa conceitual da pesquisa........................................ 22

Figura 2.1 - Esquema genérico para mapeamento e classificação dos stakeholders externos.

Figura 4.1 - Visão geral do modelo para monitoramento e avaliação de desempenho em sustentabilidade de grupos multissetoriais.

Figura 4.2 - Exemplo didático de uma matriz de materialidade de um GMS, no contexto corporativo

Figura 4.3 - Estrutura hierárquica a ser adotada pelo GMS na etapa 4 do modelo.

Figura 4.4 - Definição dos Aspectos materiais e Limites - Visão geral do processo.

Figura 5.1 - Matriz de materialidade da categoria 'Ambiental' do Grupo Algar.

Figura 5.2 - Indicadores GRI associados aos aspectos materiais da categoria 'Ambiental' priorizados na matriz de materialidade.

Figura 5.3 - Estrutura para hierarquização e seleção dos indicadores GRI 'candidatos' da categoria 'Ambiental' no contexto corporativo do Grupo Algar

Figura 5.4 - Apresentação dos resultados consolidados para EN6 (Energia) - Grupo Algar. 


\section{Lista de Quadros}

Quadro 2.1 - Modelo genérico para os critérios e elementos de autoavaliação relacionados aos níveis de maturidade........

Quadro 2.2 - Estrutura hierárquica da ferramenta de autoavaliação do Anexo A da Norma ABNT NBR ISO 9004:2010

Quadro 2.3 - Estrutura do questionário do Instituto Ethos: dimensões, temas e subtemas.

Quadro 3.1 - Estrutura hierárquica das Diretrizes G4 da GRI

Quadro 3.2 - Critérios para comparação dos sistemas de mensuração da sustentabilidade corporativa.

Quadro 3.3 - Sistemas de mensuração da sustentabilidade corporativa analisados quanto ao escopo, abrangência e nível de agregação dos dados.

Quadro 3.4 - Sistemas de mensuração da sustentabilidade corporativa analisados quanto ao nível de participação e à interface...

Quadro 4.1 - Classificação dos indicadores GRI segundo as perspectivas da ferramenta BSC.

Quadro 4.2 - Formulário para definição dos stakeholders externos do grupo multissetorial no contexto corporativo.

Quadro 4.3 - Metamodelo para elaboração das identidades dos indicadores selecionados pelo GMS e respectivas métricas.

Quadro 5.1 - Identidade do indicador EN6 - Redução do consumo de energia no Grupo Algar e nas empresas do Grupo. 


\section{Lista de Tabelas}

Tabela 4.1 - Exemplo didático da comparação pareada dos aspectos materiais da categoria 'Econômica': visão dos stakeholders internos

Tabela 4.2 - Exemplo didático da comparação pareada dos aspectos materiais da categoria 'Econômica': visão dos stakeholders externos.

Tabela 4.3 - Hierarquização dos aspectos materiais da categoria 'Econômica', segundo a visão dos stakeholders internos

Tabela 4.4 - Hierarquização dos aspectos materiais da categoria 'Econômica', segundo a visão dos stakeholders externos.

Tabela 4.5 - Parâmetros para posicionamento dos aspectos materiais nas respectivas matrizes de materialidade.

Tabela 4.6 - Exemplo de matriz de comparação pareada dos critérios para seleção dos indicadores GRI 'candidatos' da categoria Econômica'.

Tabela 4.7 - Grau de importância atribuída aos critérios para seleção dos indicadores GRI 'candidatos' da categoria 'Econômica'

Tabela 4.8 - Matriz de avaliação quantitativa de indicadores GRI 'candidatos' da categoria 'Econômica'.

Tabela $4.9-$ Soluções ideais PIS e NIS para os critérios para hierarquização e seleção dos indicadores GRI da categoria 'Econômica'.

Tabela 4.10 - Distâncias euclidianas (positivas e negativas) dos indicadores GRI da categoria 'Econômica'.............................................................. 85

Tabela 4.11 - Proximidades relativas dos indicadores GRI 'candidatos' da categoria 'Econômica' em relação à PIS......

Tabela 4.12 - Hierarquização dotabelas indicadores GRI 'candidatos' da categoria 'Econômica'....

Tabela 5.1 - Definição dos stakeholders externos do Grupo Algar no contexto corporativo......

Tabela 5.2 - Comparação pareada dos aspectos materiais da categoria 'Ambiental': visão dos stakeholders internos....

Tabela 5.3 - Comparação pareada aspectos materiais da categoria 'Ambiental': visão dos stakeholders externos...

Tabela $5.4-$ Grau de importância atribuída aos aspectos materiais da categoria 'Ambiental', segundo a visão dos stakeholders internos 
Tabela 5.5 - Grau de importância atribuída aos aspectos materiais da categoria 'Ambiental', segundo a visão dos stakeholders externos.

Tabela 5.6 - Matriz de comparação pareada dos critérios para seleção dos indicadores GRI 'candidatos' da categoria 'Ambiental'.

Tabela 5.7 - Pesos atribuídos aos critérios para seleção dos indicadores GRI 'candidatos' da categoria 'Ambiental' ....

Tabela 5.8 - Matriz de avaliação quantitativa de indicadores GRI 'candidatos' da categoria 'Ambiental' para o relatório de Sustentabilidade do Grupo Algar.

Tabela 5.9 - Soluções ideais PIS e NIS dos critérios para hierarquização e seleção dos indicadores GRI da categoria 'Ambiental'.....

Tabela 5.10 - Distâncias euclidianas (positivas e negativas) dos indicadores GRI da categoria 'Ambiental'....

Tabela 5.11 - Proximidades relativas dos indicadores GRI 'candidatos' da categoria 'Ambiental' em relação à PIS.

Tabela 5.12 - Hierarquização dos indicadores GRI 'candidatos' da categoria 'Ambiental' 


\section{Abreviaturas}

AHP - Analytic Hierarchy Process

ANP - Analytic Network Process

GMS - Grupo multissetorial

GRI - Global Reporting Initiative

$\mathrm{KPI}$ - Key performance indicators

MCDM - Multi-criteria decision making methods

TOPSIS - The Technique for Order of Preference by Similarity to Ideal Solution 


\section{Introdução}

Grupos multissetoriais (GMSs) e empresas holdings atuam em ambientes cada vez mais dinâmicos e complexos, com exigências e preocupações crescentes para atingir patamares superiores de sustentabilidade Para fazer frente a tais desafios, esses grupos vêm adotando, como boas práticas, modelos de gerenciamento estratégico e avaliação de desempenho global, verificando-se em particular uma tendência para o uso da abordagem metodológica conhecida como Balanced Scorecard, introduzida por Kaplan e Norton no início da década de 1990, e das Diretrizes da Global Reporting Initiative (GRI).

Não obstante o estágio de maturidade dos GMSs em relação à adoção desses modelos, há ainda espaço para analisar como os métodos e ferramentas atualmente empregadas podem ser integradas para o apoio efetivo a decisões estratégicas como reestruturação empresarial; definição da estratégia corporativa de baixo carbono; diversificação geográfica dos negócios (local, nacional ou multinacional); investimentos, desinvestimentos e parcerias estratégicas; e participações acionárias em novos negócios, com detenção do controle ou possibilidade de participação minoritária.

Pode-se perceber a importância crescente de adoção de sistemas de monitoramento e avaliação estratégica da sustentabilidade corporativa por grupos multissetoriais, visando fortalecer seu posicionamento competitivo sustentável no curto, médio e longo prazo. A própria resiliência alcançada pelos grupos multissetoriais não está apenas no fato de serem multissetoriais, mas também pela ampliação de suas respectivas visões de sustentabilidade, ao considerar aspectos sociais e ambientais em suas estratégias, além dos econômicos, segundo uma perspectiva de mais longo prazo.

Avalia-se que $80 \%$ do valor de mercado de uma empresa deriva de ativos intangíveis, como reconhecimento da marca, governança corporativa; imagem positiva e capacidade inovativa, dentre outros. Na perspectiva de criar de valor para 
seus stakeholders, os grupos multissetoriais tem se conscientizado cada vez mais sobre aspectos ambientais, sociais e de governança que possam proteger e agregar valor aos seus negócios, com benefícios potenciais para seu stakeholders.

Assim, considera-se relevante um novo olhar sobre as atuais práticas de gerenciamento estratégico e de avaliação de desempenho global adotadas pelos grupos multissetoriais, no sentido de melhor aproveitar as potenciais sinergias entre ferramentas consagradas que eles já empregam - como o Balanced Scorecard (Kaplan e Norton, 1992; 1997; 2000; 2003) e as Diretrizes G4 da Global Reporting Initiative (GRI, 2015).

A dissertação busca contribuir para este questionamento no contexto dos grupos multissetoriais, explorando-se a percepção de seus gestores sobre como os métodos e ferramentas atualmente empregadas poderão ser integradas para o apoio efetivo a decisões estratégicas voltados para o crescimento de forma sustentável. Outra contribuição refere-se à elaboração de subsídios para um suplemento orientativo da GRI para grupos multissetoriais (G4 Multisectoral Disclosures), que considere aspectos levantados nesta breve introdução.

Essa dissertação insere-se na linha de pesquisa "Gestão Estratégica da Inovação e Sustentabilidade" do Programa Pós-MQI do Departamento de Metrologia da Pontifícia Universidade Católica do Rio de Janeiro (PUC-Rio) no contexto de empresas holdings e grupos multissetoriais.

\section{1.}

\section{Definição do problema de pesquisa}

Considerando-se que:

(i) os grupos multissetoriais e empresas holdings enfrentam ambientes cada vez mais dinâmicos e complexos, com exigências e preocupações crescentes para atingir patamares superiores de sustentabilidade;

(ii) a importância da adoção de boas práticas de monitoramento e avaliação de desempenho em sustentabilidade é percebida por grupos multissetoriais para fazer frente a esses desafios;

(iii) inexistem suplementos orientativos específicos para grupos multissetoriais por parte da Global Reporting Initiative (GRI), cujas Diretrizes G4 são as mais utilizadas mundialmente pelas organizações para elaboração de seus relatórios de sustentabilidade; 
(iv) existem lacunas identificadas na literatura referentes ao tema central desta pesquisa, ou seja, modelos de monitoramento e avaliação de desempenho em sustentabilidade endereçados a grupos multissetoriais;

Enuncia-se a seguinte questão principal da pesquisa a ser respondida ao longo da pesquisa:

'Como os grupos multissetoriais podem definir, selecionar e hierarquizar indicadores e métricas que deverão ser considerados para monitorar e avaliar seu desempenho em sustentabilidade? E como poderão se beneficiar de uma sistemática que funcione como ferramenta de gerenciamento estratégico da sustentabilidade corporativa, além da função de comunicar e demonstrar seus resultados para os diversos stakeholders, por meio da publicação anual de seu Relatório de Sustentabilidade?'.

\section{2.}

\section{Objetivos: geral e específicos}

Buscando-se contribuir para o avanço do conhecimento sobre ferramentas de monitoramento e avaliação de desempenho em sustentabilidade na perspectiva dos grupos multissetoriais, o objetivo geral da dissertação é propor um modelo para o monitoramento e avaliação de desempenho em sustentabilidade desses grupos, mediante a integração das Diretrizes G4 da GRI à ferramenta Balanced Scorecard, com uso de métodos multicritério de apoio à decisão.

Em termos específicos, a dissertação busca:

- Discutir a contribuição dos referenciais normativos, diretrizes e guias para elaboração de relatórios de sustentabilidade no contexto dos grupos multissetoriais;

- Identificar as principais abordagens metodológicas de monitoramento e avaliação de desempenho em sustentabilidade, evidenciando-se a lacuna na literatura referente a grupos multissetoriais;

- Propor um modelo conceitual de monitoramento e avaliação estratégica de desempenho em sustentabilidade para grupos multissetoriais, com uso de métodos multicritério de apoio à decisão;

- Demonstrar empiricamente a aplicabilidade do modelo proposto no contexto de um grupo multissetorial brasileiro - Grupo Algar; 
- Fornecer à Global Reporting Initiative subsídios para a elaboração de um suplemento orientativo para grupos multissetoriais, i.e., G4 Multisectoral Disclosures.

\section{3. Motivação}

A motivação central desta pesquisa refere-se à oportunidade da proposição de diretrizes específicas para GMSs voltadas para uma melhor elaboração dos relatórios de sustentabilidade corporativos.

Alguns benefícios diretos surgem desta pesquisa, como o aprimoramento dos modelos de gerenciamento estratégico orientados para a sustentabilidade corporativa de grupos multissetoriais e a explicitação do grau de alinhamento desejável entre o processo de planejamento estratégico e a sistemática de monitoramento e avaliação de desempenho em sustentabilidade de grupos multissetoriais, baseada nas Diretrizes G4 da Global Reporting Initiative (GRI).

A GRI, como organismo proponente dessas diretrizes setoriais, poderá ser também impactada, pelo potencial de uma maior abrangência das atuais Diretrizes, mediante a inclusão do aspecto da multissetorialidade em seus documentos normativos.

Nesse contexto, dado a importância crescente da sustentabilidade para melhoria do posicionamento estratégico de grupos multissetoriais em um mundo globalizado, considera-se bastante oportuna a inclusão do aspecto da multissetorialidade na próxima revisão das Diretrizes G4 da GRI. Ao integrar modelos de gerenciamento estratégico já adotados a sistemáticas específicas para monitoramento e avaliação da sustentabilidade corporativa, os grupos multissetoriais poderão se beneficiar das sinergias ainda não exploradas na análise gerencial integrada de indicadores-chave de gerenciamento estratégico vis-à-vis indicadores de sustentabilidade.

Acredita-se que os resultados desta pesquisa, a partir da demonstração empírica da aplicabilidade do modelo proposto no âmbito de um grupo multissetorial brasileiro (Grupo Algar) poderão ser replicados ou adaptados por outros grupos multissetoriais no Brasil e no exterior. 


\section{4 . Metodologia}

Segundo a taxonomia proposta por Vergara (2005), a pesquisa pode ser considerada aplicada, descritiva e metodológica (quanto aos fins).

A figura 1.1 apresenta o desenho da pesquisa, destacando seus componentes e métodos, de acordo com três fases principais: (i) exploratória e descritiva; (ii) pesquisa aplicada; e (iii) conclusiva. Quanto aos meios de investigação, a metodologia compreende:

- Pesquisa bibliográfica e documental sobre os temas centrais da pesquisa, como indicado na fase exploratória e descritiva da figura 1.1;

- Desenvolvimento do modelo conceitual de monitoramento e avaliação de desempenho em sustentabilidade de grupos multissetoriais, com uso de métodos multicritério de apoio à decisão;

- Desenvolvimento de um estudo empírico no âmbito do Grupo Algar para demonstração da aplicabilidade do modelo no nível corporativo multissetorial.

Detalham-se, a seguir, o desenvolvimento das três fases e os resultados esperados em cada bloco da figura 1.1. Destaca-se que o desenho da pesquisa foi desenvolvido em total alinhamento com os objetivos enunciados na seção 1.2 deste capítulo.

\subsection{1.}

\section{Fase exploratória e descritiva}

Esta fase foi iniciada com pesquisa bibliográfica e documental, com o objetivo de levantar trabalhos conceituais e documentos de referência para delimitação do tema central da pesquisa - monitoramento e avaliação de desempenho em sustentabilidade de grupos multissetoriais. Em seguida, aprofundou-se a revisão bibliográfica, buscando-se identificar estudos empíricos sobre esse tema para explorar o potencial de uso de métodos de apoio à decisão que poderiam ser adotados na modelagem pretendida. 

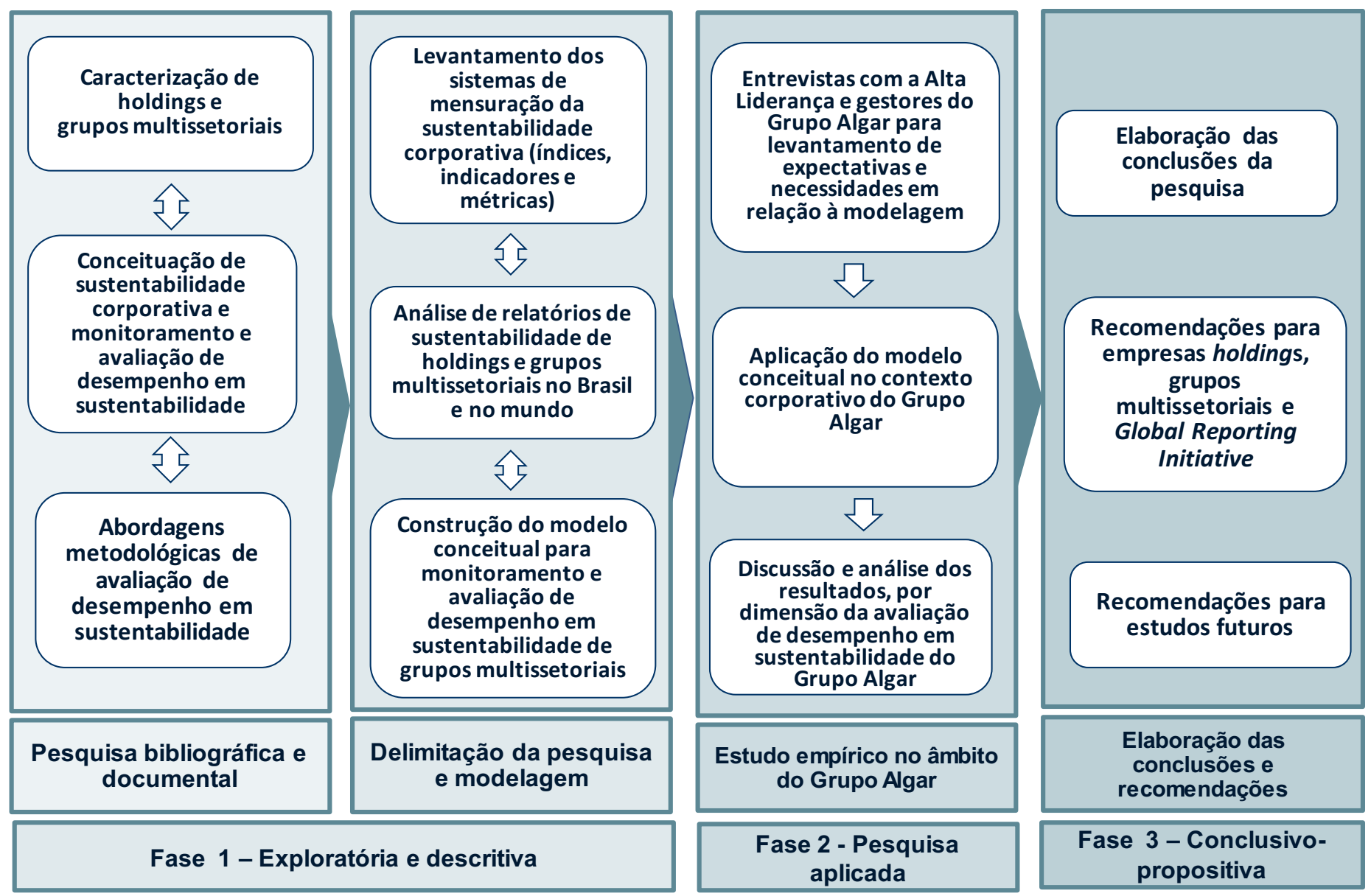

Figura 1.1 - Desenho da pesquisa, seus componentes e métodos

Fonte: Elaboração própria. 
Nesta fase exploratória e descritiva, confirmou-se a inexistência de estudos acadêmicos tendo como foco o tema de monitoramento e avaliação de desempenho em sustentabilidade de grupos multissetoriais. A ênfase dos trabalhos anteriores recaiu sobre organizações e empresas que atuam em um único setor.

A fase de modelagem compreendeu a integração de duas abordagens metodológicas - as Diretrizes G4 da Global Reporting Initiative, amplamente adotadas para elaboração de relatórios de sustentabilidade por parte de organizações e empresas dos mais diversos setores, e a ferramenta consagrada de gerenciamento estratégico, cunhada por seus autores como Balanced Scorecard - BSC (Kaplan e Norton, 1992; 1997; 2000; 2003).

A modelagem considerou a subjetividade inevitável da mensuração de percepções e julgamentos de gestores e representantes dos stakeholders dos grupos multissetoriais, ao integrar métodos multicritério para seleção dos aspectos por categoria da sustentabilidade e hierarquização dos respectivos indicadores. Ao aplicar o modelo para cada categoria da sustentabilidade (econômica, social e ambiental), os gestores poderão hierarquizar os indicadores GRI, tendo como critérios as quatro perspectivas da ferramenta BSC (financeira, mercado, processos e crescimento/aprendizagem).

Apresenta-se na figura 1.2 uma visão geral e esquemática dos resultados desta primeira fase, no formato de um mapa conceitual da pesquisa.

\subsection{2.}

\section{Fase de pesquisa aplicada}

Com o objetivo de demonstrar a aplicabilidade do modelo proposto, desenvolveu-se um estudo empírico no contexto corporativo do Grupo Algar.

Antes de se iniciar a etapa de modelagem propriamente dita na fase anterior, realizou-se uma série de entrevistas com representantes da Alta Liderança do Grupo Algar para levantar as expectativas e pontos para melhoria referentes aos procedimentos atualmente adotados na elaboração dos Relatórios de Sustentabilidade do Grupo, publicados e divulgados anualmente.

O modelo conceitual proposto nesta pesquisa levou em consideração os resultados dessas entrevistas e análises posteriores de Relatórios de Sustentabilidade de GMSs, como General Electric (GE) e Siemens, além dos referenciais teórico e normativo apresentados nos capítulos iniciais. 


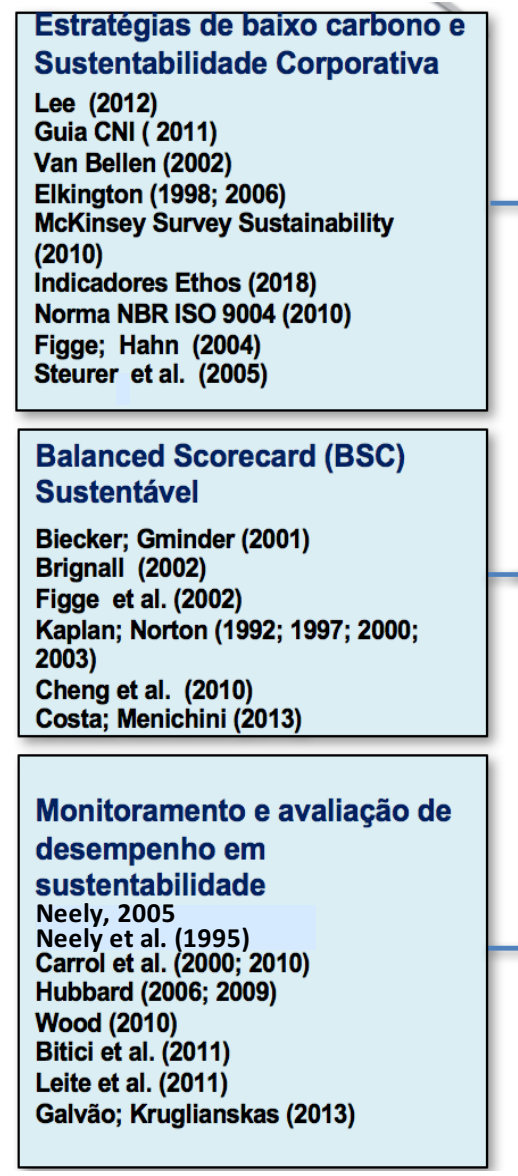

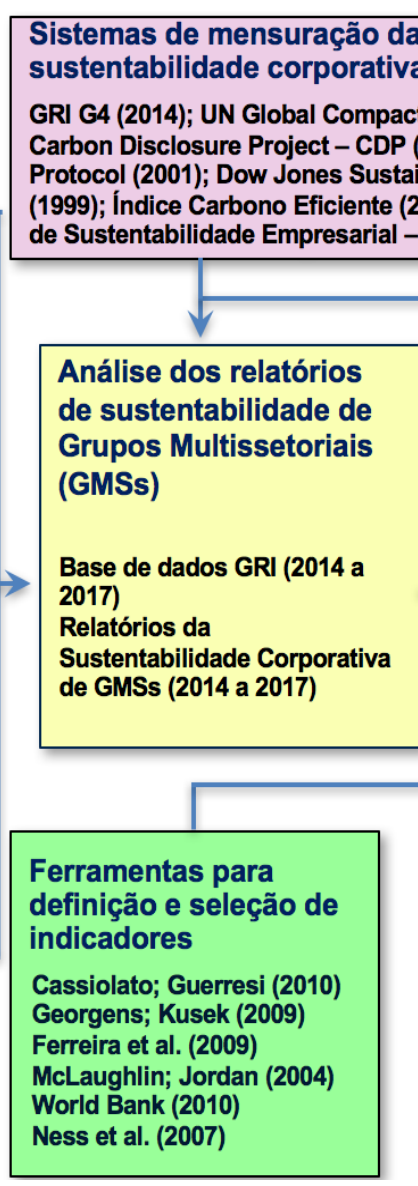

Caracterização de empresas

holdings/Grupos Multissetoriais (GMSs)

Almeida et al. (2015)

Donnini, (2016)

Mankiw et al. (1992)

Requião (2003)

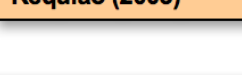

Modelagem do sistema

de avaliação de

desempenho em

sustentabilidade para

GMSs

Seleção de stakeholders

Construção da matriz de

Defriçáo da estrutura

indicadores GRI integrada à

ferramenta BSC

Avaliação de desempenho
em sustentabilidade de
grupos multissetoriais
(GMSs): proposição de um
modelo conceitual para
definição e seleção de
indicadores e métricas
$\quad$ [Questão Principal]

Métodos multicritério de apoio à decisão (AHP e TOPSIS)

Saaty $(1977 ; 1990 ; 1991 ; 2000)$ Hwang; Yoon (1981; 1995)

Roy; Vincke (1981)

Lewuis et al. (2005)

Hwang et al. (2012)

Silva et al. (2012)

Leite e Freitas (2012)

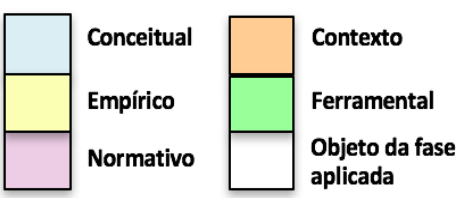

Figura 1.2 - Mapa conceitual da pesquisa

Fonte: Elaboração própria. 
O estudo empírico teve como pontos de partida a definição dos principais stakeholders externos do Grupo e construção da matriz de materialidade para seleção dos aspectos de sustentabilidade, que deverão ser foco dos próximos Relatórios de Sustentabilidade do Grupo.

Com a aplicação do modelo conceitual no contexto corporativo do Grupo Algar, foi possível priorizar os aspectos materiais da sustentabilidade mais relevantes para o Grupo e, a partir dos aspectos prioritários, selecionar e hierarquizar indicadores e métricas para integrar uma sistemática de monitoramento e avaliação estratégica da sustentabilidade corporativa deste Grupo.

Não obstante o fato do modelo ter sido aplicado apenas em um grupo multissetorial, pela sua flexibilidade e pela redução da subjetividade propiciada pelo emprego de métodos multicritério de apoio à decisão, é possível afirmar que os resultados gerados por esta pesquisa poderão ser replicados em processos de avaliação de desempenho em sustentabilidade de outros grupos multissetoriais no Brasil e no exterior. No âmbito da GRI, poderão contribuir para a elaboração de um suplemento orientativo para grupos multissetoriais, i.e., G4 Multisectoral Disclosures.

\subsection{3.}

\section{Fase conclusivo-propositiva}

Na terceira fase, elaboraram-se a conclusão geral e as específicas em relação às questões da presente pesquisa. Formulou-se ainda um conjunto de recomendações para o Grupo Algar e outros grupos multissetoriais interessados na futura aplicação de um modelo de monitoramento e avaliação de desempenho em sustentabilidade, como proposto nesta dissertação. Além dessas recomendações, sugerem-se desdobramentos desta pesquisa, com indicação de temas de estudos acadêmicos futuros.

\section{5.}

\section{Estrutura da dissertação}

A dissertação encontra-se estruturada em seis capítulos, incluindo esta introdução.

No capítulo 2, apresenta-se o referencial teórico sobre monitoramento e avaliação em sustentabilidade de organizações em geral, buscando-se identificar abordagens metodológicas e métodos multicritério de apoio à decisão com 
potencial de aplicação em grupos multissetoriais. Este referencial teórico e a análise de documentos normativos, guias e diretrizes aplicáveis à avaliação de sustentabilidade desses grupos - focos do capítulo 3 - fundamentaram a proposição de um modelo conceitual de monitoramento e avaliação em sustentabilidade para grupos multissetoriais, em resposta à lacuna identificada durante a revisão da literatura e a análise documental cobrindo o período de 1988 a 2018. Destacam-se nestes capítulos as Diretrizes G4 da Global Reporting Initiative (GRI, 2015) e a ferramenta Balanced Scorecard (Kaplan e Norton, 1992; 1997; 2000; 2003).

No capítulo 3, apresentam-se e analisam-se comparativamente os principais referenciais normativos e índices aplicáveis, particularmente as Diretrizes G4 da Global Reporting Initiative (GRI); a iniciativa Carbon Disclosure Project (CDP); o GHG Protocol; o UN Global Compact; e três índices - Dow Jones; Carbono Eficiente (ICO2); e Sustentabilidade Empresarial (ISE). A partir da análise comparativa desses referenciais, discutem-se ao final as implicações para avaliação de desempenho em sustentabilidade no contexto de grupos multissetoriais.

No capítulo 4, propõe-se um modelo conceitual para monitoramento e avaliação do desempenho da sustentabilidade corporativa de grupos multissetoriais, ressaltando-se os diferenciais deste modelo em relação às práticas atuais. O modelo compreende cinco etapas e foi desenvolvido para aplicação no nível corporativo de um GMS.

No capítulo 5, apresentam-se e discutem-se os resultados do estudo empírico no âmbito do Grupo Algar, que permitiram demonstrar a aplicabilidade do modelo conceitual proposto no capítulo anterior. O desenvolvimento deste estudo teve como resultado final a proposta de um processo estruturado a ser adotado pelo Grupo, desde a definição dos seus principais stakeholders, que participarão da construção da matriz de materialidade, até a seleção dos indicadores e métricas de monitoramento e avaliação estratégica da sustentabilidade do Grupo Algar no nível corporativo multissetorial.

No capítulo 6, formulam-se as conclusões da pesquisa e endereçam-se propostas para estudos futuros, como desdobramentos naturais e aprofundamento de aspectos relevantes que emergiram desta dissertação. 


\section{2 \\ Monitoramento e avaliação de desempenho em sustentabilidade}

Apresenta-se o referencial teórico sobre monitoramento e avaliação da sustentabilidade corporativa de organizações em geral, buscando-se identificar abordagens metodológicas e métodos multicritério de apoio à decisão com potencial de aplicação em grupos multissetoriais. Este referencial teórico, juntamente com a análise de documentos normativos aplicáveis à avaliação da sustentabilidade corporativa desses grupos, foco do capítulo 3, fundamentaram a proposição de um modelo conceitual de monitoramento e avaliação em sustentabilidade para GMSs, em resposta à lacuna identificada durante a revisão da literatura e a análise documental cobrindo o período de 1988 a 2018.

\section{1. \\ Conceitos básicos}

Antes de se abordar o referencial teórico propriamente dito, apresentam-se os principais conceitos e definições referentes a: (i) grupos multissetoriais; (ii) sustentabilidade corporativa e responsabilidade social empresarial; e (iii) avaliação de desempenho em sustentabilidade.

\subsubsection{Grupos multissetoriais}

Um grupo multissetorial (GMS) é composto pelo conjunto de participações acionárias em organizações/empresas, sendo que cada organização/empresa ou cada setor em que o GMS atua apresenta características que merecem uma avaliação diferenciada. A multissetorialidade tem por base necessariamente a estrutura de grupos empresariais que, segundo Requião (2003), são sociedades isoladas que se relacionam sob a forma de coligadas e controladas, no sentido de terem otimização de estruturas.

Os grupos multissetoriais são formados de fato entre sociedades coligadas ou entre a controladora e a controlada. $\mathrm{O}$ termo holding também é bastante difundido e utilizado no Brasil e significa companhia controladora, não precisando ser 
constituída com a única finalidade de administrar outras empresas, sendo neste caso denominada holding mista, porém, quando tem como única atividade controlar sociedades, ela é chamada holding pura (Couto, 2012, p. 26).

\subsection{2.}

\section{Sustentabilidade corporativa e responsabilidade social empresarial}

Associada ao conceito de desenvolvimento sustentável, divulgado pelo Relatório Brundtland ${ }^{1}$, sustentabilidade corporativa pode ser definida como a adoção de estratégias e práticas que atendam às necessidades da organização e seus stakeholders hoje, preservando e sustentando recursos naturais e humanos que serão necessários no futuro. Refere-se, portanto, à busca, por parte das organizações, de novos modelos de gestão, que considerem critérios e indicadores das dimensões social e ambiental, além da econômica, em seus processos de decisão e operações (Hedstrom et al.; 1998; Epstein e Roy, 2003; Epstein, 2008; Dunphy et al., 2007; Van Marrewijk e Werre, 2003; Schaltegger et al., 2003; Schaltegger e Wagner, 2006).

Parte-se do pressuposto que as atividades socioprodutivas geram externalidades positivas e negativas. A título de ilustração, o desenvolvimento econômico e social de uma determinada região promovido pela instalação de uma fábrica é uma externalidade positiva. Já o nível alto de emissões atmosféricas decorrentes de uma atividade produtiva é considerado como uma externalidade negativa.

Não obstante o fato de que muitas organizações no mundo percebem a abordagem de sustentabilidade corporativa como muito importante para a criação de valor para as partes interessadas, a maioria não sabe ainda como gerar opções de valor segundo tal abordagem, particularmente no curto prazo. Trata-se de um processo de transição contínuo, desde as atividades de curto prazo, de ganho imediato, até iniciativas de médio e longo prazo, que proporcionem vantagens competitivas sustentáveis em horizontes mais distantes (Van Marrewijk e Werre, 2003; Schaltegger et al., 2003; Hart e Milstein, 2004; Schaltegger e Wagner, 2006).

Frente aos desafios de incorporação da sustentabilidade nas práticas das organizações, diversos modelos e abordagens metodológicas têm sido endereçadas às empresas que desejam atuar no modo sustentável (Epstein e Roy, 2003;

\footnotetext{
1 “Desenvolvimento sustentável é aquele desenvolvimento que permite as gerações atuais satisfazer suas necessidades sem comprometer a capacidade das futuras gerações" (WCED, 1987, p.46).
} 
Schaltegger et al., 2003; Van Marrewijk e Werre, 2003; Epstein, 2008; Schaltegger e Wagner, 2006; Dunphy et al., 2007).

Dentre esses, pode-se citar a abordagem Triple Bottom Line (TBL) concebida por John Elkington (1998) e o modelo da Teoria dos Capitais, proposto por Porritt (2001) e reconfigurado por Dyllick e Hockerts (2002).

Destaca-se, para fins da presente pesquisa, a abordagem Triple Bottom Line (TBL). Segundo Elkington (1998), o modelo de negócio tradicional, que considerava apenas os fatores econômicos na avaliação de uma organização, deveria se expandir para um novo modelo que contemplasse a preservação ambiental e a equidade social, além da sustentabilidade econômico-financeira. O autor argumenta que se pode alcançar uma perspectiva mais ampla da sustentabilidade na organização, quando se considera a intersecção de todos os aspectos da Triple Bottom Line, com responsabilidade social.

O segundo conceito que se aborda nesta seção refere-se à responsabilidade social corporativa empresarial, que é diretamente relacionado ao primeiro. Uma definição consagrada de responsabilidade social empresarial (RSE) foi proposta por representantes do World Business Council for Sustainable Development, em 1998, na Holanda:

[...] responsabilidade social empresarial é o comprometimento permanente das organizações de adotar um comportamento ético e contribuir para o desenvolvimento econômico, melhorando, simultaneamente, a qualidade de vida de seus colaboradores e de suas famílias, da comunidade local e da sociedade como um todo (WBCSD, 2000, p.2).

Uma segunda definição foi formulada pelo Instituto Ethos de Empresas e Responsabilidade Social, complementando a anterior. Refere-se à RSC como:

[...] a forma de gestão que se define pela relação ética e transparente da empresa com todos os públicos com os quais se relaciona e pelo estabelecimento de metas empresariais compatíveis com o desenvolvimento sustentável da sociedade, preservando recursos ambientais e culturais para gerações futuras, respeitando a diversidade e promovendo a redução das desigualdades sociais (Instituto Ethos, 2007).

Observa-se que o conceito de RSE está sempre associado ao engajamento dos stakeholders e à sustentabilidade corporativa nas dimensões econômica, social e ambiental. De fato, esse conceito vem se consolidando de forma multidimensional e sistêmica, com foco na interdependência entre os fatores que levam à 
sustentabilidade e na interconectividade entre os diversos públicos de interesse ligados direta ou indiretamente aos negócios do GMS.

Com a difusão do conceito de RSE, as organizações passaram a repensar seu papel, suas obrigações e, principalmente, a forma como conduzem suas operações e relações. RSC refere-se a uma atitude holística, socialmente responsável e ética em todas as relações, quer sejam com os acionistas, os empregados, a comunidade, os fornecedores, os clientes, os governos e o meio ambiente (Carroll, 1991; 1999; Carroll e Shabana, 2010; Zadek, 1998; 2004; Porter e Kramer, 2006; Wood, 2010).

A partir de uma análise de 37 definições de RSE, Dahlsrud (2008) chegou à conclusão de que embora as definições analisadas guardem entre si alinhamento e coerência, elas não trazem uma orientação sobre como a responsabilidade social é ou deve ser assumida por uma organização que atua em um determinado contexto econômico, cultural e social.

Carroll $(1991 ; 1999)$ refere-se a quatro categorias de RSE e seu modelo inclui responsabilidades econômicas, legais, éticas e voluntárias e associa-se ao princípio de que a responsabilidade social empresarial não deve ser avaliada de forma independente do desempenho econômico da organização, sendo, portanto, parte de seu desempenho global. Esse princípio também orienta a abordagem TBL, concebida por Elkington (1998), e também a abordagem metodológica de Balanced Scorecard sustentável, que foi proposta por Figge et al. (2002). Essa questão será retomada, quando os modelos, referenciais normativos e índices voltados para a avaliação de desempenho em sustentabilidade das organizações forem discutidos na próxima seção e no capitulo 3, adiante.

\subsection{3.}

\section{Avaliação de desempenho em sustentabilidade}

Apresentam-se alguns conceitos de sistemas de avaliação de desempenho a partir dos trabalhos de revisão de Neely (2005); Hubbard (2006; 2009); Nelling e Webb (2009); Sebhatu (2011) Fiksel et al. (1999).

Neely, Gregory e Platts (1995) definem a medição de desempenho como o processo de quantificar uma ação realizada e associam este processo a dois conceitos consagrados na área de gestão: eficiência e eficácia. A eficiência referese à medida de como se utilizam os recursos disponíveis na organização para atingir um determinado nível de satisfação dos clientes e partes interessadas. Segundo o 
conceito de eficácia, a organização avalia se os requisitos dos clientes e partes interessadas estão atendidos.

Complementam a definição acima, ao afirmarem que:

"um sistema de medição de desempenho permite que as decisões e ações sejam tomadas pelos gestores de uma organização, com base em informações sobre as ações que já foram realizadas, mediante coleta, classificação de dados, análise, interpretação e disseminação da informação útil” (Neely, Gregory e Platts, 1995, p. 80).

Na perspectiva da sustentabilidade, Carroll e Shabana (2010) e Wood (2010) ressaltam que os modelos de avaliação de desempenho global das organizações devem considerar e integrar as três dimensões da sustentabilidade - social, ambiental e econômica, conforme a abordagem TBL de Elkington (1998), incluindo os principais aspectos de responsabilidade social corporativa.

De fato, existe hoje uma grande diversidade de indicadores de desempenho em sustentabilidade, sendo que a escolha por parte das organizações dos indicadores mais adequados para avaliar seu desempenho depende do tipo, porte, objetivos estratégicos e contexto de atuação da organização (Neely, 2005; Sebhatu, 2011).

A título de ilustração, as Diretrizes G4 da Global Reporting Initiative definem 91 indicadores, organizados nas dimensões econômica, ambiental e social (ver anexo 1). No entanto, na fase de planejamento da elaboração do relatório de sustentabilidade pelo grupo multissetorial, a escolha dos indicadores dependerá dos fatores citados e também da importância atribuída pelos stakeholders (internos e externos) por ocasião da construção da matriz de materialidade, como abordado na seção 2.3.

Além dos objetivos da mensuração de desempenho em sustentabilidade, é preciso considerar o perfil institucional do grupo multissetorial, os setores em que atua, a proximidade aos mercados consumidores sensíveis às questões ambientais e sociais, ao cumprimento de regulamentações aplicáveis e, ainda, à cultura corporativa do GMS (Fiksel et al. 1999). 


\section{2.}

\section{Abordagens metodológicas para monitoramento e avaliação de desempenho em sustentabilidade}

Apresentam-se nesta seção os resultados da revisão bibliográfica sobre as principais abordagens metodológicas voltadas para o monitoramento e avaliação de desempenho em sustentabilidade, com o objetivo de discutir aspectos relevantes a serem incorporados na fase de modelagem propriamente dita. São eles: (i) Balanced Scorecard sustentável; (ii) McKinsey Survey on Sustainability; (iii) Norma ABNT NBR ISO 9004:2010; (iv) Indicadores Ethos para negócios sustentáveis e responsáveis; e (v) Guia da Confederação Nacional da Indústria (CNI) para Estratégias de Baixo Carbono.

\subsection{1.}

\section{Balanced Scorecard sustentável}

Balanced Scorecard ou BSC é uma ferramenta de gerenciamento que se consagrou nas últimas décadas como um sistema de gerenciamento estratégico, comunicação e medição de desempenho de organizações das mais diversas categorias - empresas, prefeituras, ONGs e agências governamentais.

A implementação do BSC permite criar uma visão compartilhada dos objetivos de longo prazo e definir metas de curto e médio prazo para alcance desses objetivos em todos os níveis da organização.

Ao comparar-se o BSC com sistemas de gerenciamento estratégico convencionais, baseados exclusivamente na perspectiva financeira, a ferramenta se mostra capaz de orientar a organização para a sua visão de futuro, definindo quais os objetivos a atingir e medindo seus resultados a partir de quatro perspectivas distintas e integradas entre si (Kaplan e Norton, 1992; 1997; 2000; 2003).

O objetivo principal do BSC é fazer com que a organização seja capaz de entender e implementar as estratégias, incorporando ao sistema de monitoramento e avaliação de desempenho indicadores de resultado, tanto financeiros como não financeiros.

$\mathrm{Na}$ sua versão original, como ferramenta de gerenciamento estratégico, o BSC contempla quatro perspectivas para mensuração do desempenho global da organização: (i) financeira; (ii) clientes/visão externa (mercado); (iii) processos internos; e (iv) crescimento e aprendizagem. 
No entanto, busca-se nesta seção explorar o potencial de aplicação do BSC como ferramenta de monitoramento e avaliação do desempenho sustentável de grupos multissetoriais.

O conceito de BSC sustentável teve importantes discussões e desdobramentos em trabalhos como de autores como Bieker e Gminder (2001); Figge et al. (2002); Dyllick e Hockerts (2002); Brignall (2002); Bieker (2005); Cheng et al. (2010); Costa e Menichini (2013); Arora (2015); e Kalendera e Vayvay (2016).

Inicialmente, autores como Bieker e Gminder (2001), Figge et al. (2002), Dyllick e Hockerts (2002), Brignall (2002) e Bieker (2005) argumentaram que o uso dos recursos financeiros e humanos de forma eficiente já não se configurava mais como o único fator determinante para promover competitividade nas organizações, como havia sido concebido por Kaplan e Norton. Na visão sustentabilidade, os aspectos intangíveis, como por exemplo, o desempenho ambiental e a atuação social, cada vez mais têm tido sua importância reconhecida nos relatórios de sustentabilidade das organizações em geral.

Nesse contexto, busca-se mostrar como os Grupos Multissetoriais podem se beneficiar de seu uso, incorporando adaptações ao conceito original. A criação de um BSC sustentável permite considerar e implementar os aspectos ambientais e sociais por toda a organização e com a visão estratégica, mensurando e comunicando a sustentabilidade corporativa mediante indicadores-chave de desempenho nas suas três dimensões: (i) econômica; (ii) social; e (iii) ambiental.

Com o objetivo de integrar os aspectos ambientais e sociais ao BSC convencional, Figge et al. (2002) sugerem três alternativas, a saber: (i) incorporação das dimensões ambiental e social em três das perspectivas originais do BSC; (ii) criação de uma quinta perspectiva exclusiva para as dimensões ambiental e social; e (iii) criação de um BSC exclusivo para a sustentabilidade ambiental e social, porém dependente de uma das alternativas anteriores.

A integração dos aspectos ambientais e social com as perspectivas estratégicas financeiras e não financeiras de uma organização motiva a união das Diretrizes G4 da Global Reporting Initiative (GRI) com a ferramenta do Balanced Scorecard (BSC).

Baseando-se nesta definição, Costa e Menichini (2013) apresentam uma adaptação do modelo proposto por Panayiotou et al. (2009), onde propuseram uma 
integração do GRI com BSC, onde os indicadores GRI são classificados sob as perspectivas do BSC (Kaplan e Norton, 1992; 1997; 2000; 2003).

Com isto, os relatórios de sustentabilidade corporativos baseado nas Diretrizes GRI ficam atrelados às estratégias corporativas ao correlacionarem indicadores GRI com as perspectivas e objetivos declarados no Mapa Estratégico do BSC.

Arora (2015) evidencia as sinergias entre GRI e BSC. Primeiramente a partir do fato da ampla aceitação corporativa pelas diretrizes GRI no mundo todo, em seguida para justificar essa ampla adoção pelo modelo que inclui ampla gama de categorias/subcategorias, aspectos e indicadores, facilitando assim que empresas de diferentes setores, com diferentes expectativas possam produzir seus relatórios de sustentabilidade a partir de diferentes conjuntos de indicadores selecionados e combinados. A autora apresenta o pensamento de Wilenius (2005) que defende ser um desafio para as organizações a integração da sustentabilidade com a estratégia corporativa, e também a realização do alinhamento dos princípios da sustentabilidade com os valores centrais da organização.

O trabalho de Arora (2015) ressalta a importância estratégica do BSC por fornecer retornos voltados para o alinhamento das perspectivas de maneira equilibrada, com o objetivo do alcance dos resultados de negócios almejados. Arora (2015) afirma que recentes estudos como o de Nikolaou e Tsalis (2013) consideram o BSC como uma ferramenta para a avaliação da sustentabilidade corporativa, destacando como ponto forte a sinergia entre a estrutura de indicadores de sustentabilidade da GRI e a abordagem metodológica do BSC sustentável.

O modelo aqui proposto permite integrar as diretrizes GRI e respectivos indicadores de sustentabilidade com as perspectivas da ferramenta Balanced Scorecard, contribuindo para o gerenciamento estratégico efetivo e sistêmico da sustentabilidade de GMSs.

\subsection{2.}

\section{McKinsey Survey on Sustainability}

A McKinsey é uma empresa global de consultoria de gestão com quase um século de vida que atende uma ampla gama de instituições do setor privado, público e social, ou seja, atua multissetorialmente. Possuiu escritórios em mais de 120 cidades espalhadas pelo mundo e possui mais de 14.000 consultores especializados. 
A pesquisa específica da McKinsey sobre sustentabilidade explora como as empresas definem a sustentabilidade, como gerenciam, por que se envolvem em atividades relacionadas à sustentabilidade e como elas avaliam e comunicam esse envolvimento.

De acordo a pesquisa conduzida em fevereiro de 2010 que obteve 1946 respostas qualificadas de executivos da mais ampla gama de empresas, a McKinsey afirmava que mais de $50 \%$ dos executivos das empresas pesquisadas consideram a sustentabilidade muito ou extremamente importante em uma ampla gama de áreas, incluindo desenvolvimento de novos produtos, construção de reputação e estratégia corporativa geral. No entanto, a pesquisa apontava que que apenas $30 \%$ dos executivos dizem que suas empresas procuram ativamente oportunidades para investir em sustentabilidade ou incorporá-las em suas práticas comerciais, uma oportunidade concreta para uma abordagem proativa no tocante ao gerenciamento da sustentabilidade.

Em 2010, para a McKinsey, as empresas eram definidas como sendo mais comprometidas com a sustentabilidade se seus executivos afirmam que a sustentabilidade é uma das principais prioridades nas agendas de seus Chief Executive Officers (CEOs), sendo formalmente incorporada às práticas de negócios e que suas empresas são "extremamente" ou "muito efetivas" em gerenciá-la. A McKinsey também afirmava que as empresas mais comprometidas com a sustentabilidade se tornavam mais vantajosas do que outras para obter valor na forma de construção de reputação, economia de custos e oportunidades de crescimento.

Na mais recente edição da pesquisa de dezembro de 2017 com 2711 participantes, a McKinsey afirma empresas estão mais ativas do que nunca na busca da sustentabilidade para alinhar com valores e envolver as partes interessadas e que para ver os retornos financeiros a integração da sustentabilidade nas funções principais é fundamental. À medida que as questões ambientais, sociais e de governança se tornaram cada vez mais importantes influenciadores das expectativas dos clientes e dos funcionários, as organizações fortaleceram seus programas de sustentabilidade que abordam essas questões.

De acordo com o último McKinsey Global Survey, empresas formalizam cada vez mais a forma como eles conduzem os programas de sustentabilidade. Afirma também que a maioria dos entrevistados entende que a principal razão para 
implementar uma agenda de sustentabilidade é um melhor alinhamento entre as práticas de uma organização com seus objetivos, missões ou valores.

Apesar desses avanços, muitas organizações ainda lutam para capturar o valor financeiro de seus esforços de sustentabilidade. Integrar a sustentabilidade em uma ou mais funções principais do negócio, por exemplo, é uma prática que pode ajudar. A integração da sustentabilidade no trabalho funcional duplica a probabilidade de uma empresa reportar o valor financeiro desses esforços. No tocante à lacuna entre valores e ação os entrevistados relatam poucas mudanças no número de atividades que suas organizações estão buscando para atingir os objetivos de sustentabilidade.

A pesquisa abordou cerca de 11 dessas atividades em três categorias: crescimento, retorno do capital e gerenciamento de riscos, como metodologia utilizada desde 2011. Nas áreas onde as organizações eram mais ativas nos anos anteriores (gerenciando reputação, melhorando a eficiência dos recursos e respondendo à regulamentação restrições) permanecem ativos ainda. As empresas são mais ativas do que antes em apenas três das 11 áreas. Mas, de acordo com as razões mais comuns pelas quais as organizações estão buscando a sustentabilidade, duas dessas três áreas relacionam-se aos funcionários e clientes: envolver funcionários em atividades relacionadas à sustentabilidade e comunicar melhor atributos e esforços relacionados à sustentabilidade para os clientes (McKinsey, 2018).

\subsection{3.}

Norma ABNT NBR ISO 9004:2010

Intitulada como "Gestão para o Sucesso Sustentado de uma Organização uma abordagem da gestão da qualidade”, a Norma ABNT NBR ISO 9004:2010 fornece orientação para apoiar qualquer organização, que esteja inserida em um ambiente complexo e de constantes mudanças, a alcançar o sucesso sustentado, segundo uma abordagem da gestão da qualidade.

Define sucesso sustentado como o resultado da capacidade de uma organização para alcançar e manter seus objetivos de longo prazo. Considera ambiente da organização a combinação de fatores internos e externos, além de condições que podem afetar o alcance dos objetivos da organização e seu comportamento em relação às suas partes interessadas (ABNT/ISO, 2010). 
Segundo a referida Norma, o sucesso sustentado de uma organização pode ser alcançado pela sua habilidade de atender às necessidades e expectativas de seus clientes e demais partes interessadas, com visão de longo prazo e de forma equilibrada. Nessa perspectiva, a Norma oferece uma visão mais ampla do que a ABNT NBR ISO 9001, pois aborda as necessidades das partes interessadas e questões de responsabilidade social corporativa.

O caráter técnico da Norma ABNT NBR ISO 9004:2010 não é de certificação. Ela é um guia técnico para autoavaliação da organização, visando a melhoria sistemática e contínua de seu desempenho global. Esta Norma possui três anexos. O Anexo A apresenta uma ferramenta de autoavaliação para que as organizações possam identificar lacunas em seu sistema de gestão e oportunidades de melhorias e de inovação. O Anexo B descreve princípios de gestão da qualidade e o Anexo C fornece uma correspondência, seção por seção entre a ABNT NBR ISO 9001:2008 e a ABNT NBR ISO 9004:2010.

A ferramenta de autoavaliação constante do Anexo A apresenta um modelo genérico para os critérios e elementos de autoavaliação, relacionados aos níveis de maturidade, como apresentado no referido Anexo dessa Norma (quadro 2.1).

Quadro 2.1 - Modelo genérico para os critérios e elementos de autoavaliação relacionados aos níveis de maturidade

\begin{tabular}{|l|l|l|l|l|l|}
\hline \multirow{2}{*}{$\begin{array}{l}\text { Elemento- } \\
\text { chave }\end{array}$} & \multicolumn{5}{|l|}{ Níveis de maturidade em direção ao sucesso sustentado } \\
\cline { 2 - 6 } & Nível 1 & Nível 2 & Nível 3 & Nível 4 & Nível 5 \\
\hline Elemento 1 & $\begin{array}{l}\text { Critério 1 } \\
\text { Nível básico }\end{array}$ & & & & $\begin{array}{l}\text { Critério 1 } \\
\text { Melhor prática }\end{array}$ \\
\hline Elemento 2 & $\begin{array}{l}\text { Critério 2 } \\
\text { Nível básico }\end{array}$ & & & & $\begin{array}{l}\text { Critério 2 } \\
\text { Melhor prática }\end{array}$ \\
\hline Elemento 3 & $\begin{array}{l}\text { Critério 3 } \\
\text { Nível básico }\end{array}$ & & & & $\begin{array}{l}\text { Critério 3 } \\
\text { Melhor prática }\end{array}$ \\
\hline
\end{tabular}

Fonte: ABNT/ISO (2010).

A seguir, no quadro 2.2, apresenta-se a estrutura da ferramenta de autoavaliação propriamente dita. São seis elementos-chave de avaliação, em um primeiro nível hierárquico, e 28 elementos detalhados, em um segundo nível.

A Norma sugere que a organização, por meio da ferramenta de autoavaliação, desenvolva e mantenha a capacidade de mudar e inovar, como resposta a sinais de mudança do ambiente externo, como oportunidades, ameaças e desafios. Segundo essa visão, espera-se que a organização alcance o sucesso sustentado frente a eventuais turbulências de seu contexto socioprodutivo, atendendo de forma 
balanceada as necessidades e expectativas das partes interessadas no curto, médio e longo prazo.

A abordagem de sucesso sustentado adotada pela Norma é distinta daquela discutida na introdução deste capítulo. O termo 'sucesso sustentado' de uma organização, conforme a Norma, não está diretamente relacionado com questões éticas e ambientais de organizações que buscam deixar um mundo mais 'verde' e com justiça social para as próximas gerações.

Apesar da Norma enfatizar claramente a melhoria contínua, eficiência e eficácia do sistema de gestão, o documento inclui, dentre os elementos detalhados, aspectos de responsabilidade social, engajamento das partes interessadas e visão de longo prazo. Esses últimos são fatores fundamentais para a sustentabilidade corporativa, como discutido anteriormente.

Quadro 2.2 - Estrutura hierárquica da ferramenta de autoavaliação do Anexo A da Norma ABNT NBR ISO 9004:2010

\begin{tabular}{|c|c|}
\hline Elemento chave & Elementos detalhados \\
\hline \multirow{4}{*}{$\begin{array}{l}\text { 1. Gestão para o sucesso } \\
\text { sustentado de uma organização }\end{array}$} & 1.1 Generalidades \\
\hline & 1.2 Sucesso sustentado \\
\hline & 1.3 Ambiente da organização \\
\hline & 1.4 Necessidades e expectativas das partes interessadas \\
\hline \multirow[t]{4}{*}{ 2. Estratégia e política } & 2.1 Generalidades \\
\hline & 2.2 Estratégia e formulação de políticas \\
\hline & 2.3 Estratégia e desdobramento das políticas \\
\hline & 2.4 Comunicação da estratégia e políticas \\
\hline \multirow[t]{8}{*}{ 3. Gestão de recursos } & 3.1 Generalidades \\
\hline & 3.2 Recursos financeiros \\
\hline & 3.3 Pessoas da organização \\
\hline & 3.4 Fornecedores e parceiros \\
\hline & 3.5 Infraestrutura \\
\hline & 3.6 Ambiente de trabalho \\
\hline & 3.7 Conhecimento, informação e tecnologia \\
\hline & 3.8 Recursos naturais \\
\hline \multirow[t]{3}{*}{ 4. Gestão de processos } & 4.1 Generalidades \\
\hline & 4.2 Planejamento e controle de processos \\
\hline & 4.3 Responsabilidade e autoridade pelos processos \\
\hline \multirow{5}{*}{$\begin{array}{l}\text { 5. Monitoramento, medição, } \\
\text { análise do desempenho e análise } \\
\text { crítica pela direção }\end{array}$} & 5.1 Generalidades \\
\hline & 5.2 Monitoramento \\
\hline & 5.3 Medição \\
\hline & 5.4 Análise do desempenho \\
\hline & $\begin{array}{l}5.5 \text { Análise crítica das informações de monitoramento, medição e } \\
\text { análise }\end{array}$ \\
\hline \multirow{4}{*}{$\begin{array}{l}\text { 6. Melhoria, Inovação e } \\
\text { aprendizagem }\end{array}$} & 6.1 Generalidades \\
\hline & 6.2 Melhoria \\
\hline & 6.3 Inovação \\
\hline & 6.4 Aprendizagem \\
\hline
\end{tabular}

Fonte: ABNT/ISO (2010). 


\subsection{4}

\section{Indicadores Ethos para negócios sustentáveis e responsáveis}

Os Indicadores Ethos para Negócios Sustentáveis e Responsáveis são uma ferramenta de gestão que têm como foco avaliar o quanto a sustentabilidade e a responsabilidade social têm sido incorporadas nos negócios, auxiliando a definição de estratégias, políticas e processos das organizações. Embora traga medidas de desempenho em sustentabilidade e responsabilidade social, esta ferramenta não se propõe a medir o desempenho das empresas em si, nem reconhecer organizações como sustentáveis ou responsáveis. (Instituto Ethos, 2018).

A ferramenta é composta por um questionário, que permite a autoavaliação do desempenho da organização na perspectiva da sustentabilidade e um sistema de preenchimento on-line, que possibilita a obtenção de relatórios, por meio dos quais é possível fazer o planejamento e a gestão de metas para o avanço da gestão e adoção de práticas de RSC e maior orientação para sustentabilidade corporativa (quadro 2.3).

Quadro 2.3 - Estrutura do questionário do Instituto Ethos: dimensões, temas e subtemas

\begin{tabular}{|c|c|c|c|}
\hline Dimensão & Temas & Subtemas & $\begin{array}{l}\text { № de } \\
\text { indicadores }\end{array}$ \\
\hline Visão e Estratégia & - & - & 3 \\
\hline \multirow{6}{*}{$\begin{array}{l}\text { Governança e } \\
\text { Gestão }\end{array}$} & \multirow{2}{*}{$\begin{array}{l}\text { Governança } \\
\text { organizacional }\end{array}$} & Governança e conduta & 4 \\
\hline & & Prestação de contas & 3 \\
\hline & \multirow{4}{*}{$\begin{array}{l}\text { Práticas de } \\
\text { operação e } \\
\text { gestão }\end{array}$} & Práticas concorrenciais & 1 \\
\hline & & Práticas anticorrupção & 1 \\
\hline & & Envolvimento político responsável & 1 \\
\hline & & Sistema de gestão & 5 \\
\hline \multirow[t]{8}{*}{ Social } & \multirow[t]{2}{*}{$\begin{array}{l}\text { Direitos } \\
\text { humanos }\end{array}$} & $\begin{array}{l}\text { Situações de risco para os direitos } \\
\text { humanos }\end{array}$ & 3 \\
\hline & & Ações afirmativas & 1 \\
\hline & \multirow{3}{*}{$\begin{array}{l}\text { Práticas de } \\
\text { trabalho }\end{array}$} & Relações de trabalho & 2 \\
\hline & & $\begin{array}{l}\text { Desenvolvimento humano, } \\
\text { benefícios e treinamento }\end{array}$ & 3 \\
\hline & & $\begin{array}{l}\text { Saúde e segurança no trabalho e } \\
\text { qualidade de vida }\end{array}$ & 2 \\
\hline & \multirow{2}{*}{$\begin{array}{l}\text { Questões } \\
\text { relativas ao } \\
\text { consumidor }\end{array}$} & Respeito ao Direito do consumidor & 2 \\
\hline & & Consumo consciente & 1 \\
\hline & $\begin{array}{l}\text { Envolvimento } \\
\text { com a } \\
\text { comunidade e } \\
\text { seu } \\
\text { desenvolvimento }\end{array}$ & $\begin{array}{l}\text { Gestão de impactos na } \\
\text { comunidade e seu } \\
\text { desenvolvimento }\end{array}$ & 3 \\
\hline \multirow[t]{3}{*}{ Meio ambiente } & \multirow[t]{3}{*}{ Meio Ambiente } & Mudanças climáticas & 2 \\
\hline & & $\begin{array}{l}\text { Gestão e Monitoramento dos Im- } \\
\text { pactos sobre os Serviços } \\
\text { Ecossistêmicos e a Biodiversidade }\end{array}$ & 7 \\
\hline & & Impactos de consumo & 2 \\
\hline Total: 4 dimensões & 7 temas & 17 subtemas & $\begin{array}{l}46 \\
\text { indicadores }\end{array}$ \\
\hline
\end{tabular}

Fonte: Instituto Ethos (2018). 
Como pode ser observado no quadro 2.3, o questionário é agrupado em quatro dimensões, que seguem o conceito 'Environmental, Social and Governance' (ESG), sendo complementado pela dimensão 'Visão e Estratégia'. As dimensões, por sua vez, desdobram-se em nove temas, 17 subtemas e, posteriormente, em 46 indicadores. Enunciam-se questões de profundidade, questões binárias e questões quantitativas. Cada um dos 46 indicadores é composto por esses três tipos de questões, sendo as de profundidade e as binárias obrigatórias para a elaboração do relatório de diagnóstico. As questões quantitativas são opcionais e o Instituto Ethos recomenda que sejam preenchidas na etapa de planejamento.

Segundo o Instituto Ethos (2018), a atual geração desta ferramenta apresenta uma nova abordagem para a gestão das organizações e busca integrar os princípios e práticas de RSC com os objetivos para a sustentabilidade corporativa. Busca maior integração com as Diretrizes G4 da Global Reporting Initiative (GRI), com a Norma de Responsabilidade Social ABNT NBR ISO 26000, Carbon Disclosure Project (CDP) e outras iniciativas voltadas para avaliação de desempenho das organizações em sustentabilidade.

\subsubsection{Guia da Confederação Nacional da Indústria (CNI) para Estratégias de Baixo Carbono}

A Confederação Nacional da Indústria (CNI) entende que é de sua responsabilidade auxiliar a indústria brasileira em relação aos impactos causados pelas mudanças climáticas no médio e longo prazo. No entendimento da CNI, quanto mais rápido aconteçam investimentos para a inclusão da variável "clima" nas estratégias corporativas, maior a probabilidade de as organizações responderem adequadamente à nova economia de baixo carbono que cresce em ritmo acelerado.

O cenário atual não permite mais que o controle de Gases de Efeito Estufa (GEE) seja somente uma agenda imposta sob o argumento ambiental, pois o mercado passou a exigir das corporações que suas estratégias de médio e longo prazo tratem o tema com total comprometimento.

Riscos e oportunidades surgem como fatores condicionantes, cuja natureza depende das seguintes dimensões: (i) social; (ii) econômica; (iii) técnica; e (iv) institucional/política. Os tipos de riscos são subdivididos em físicos, regulatórios, reputação e competitivos. Já as oportunidades apresentam-se em economia de custos, geração de novas receitas, aumento do valor das ações, maior acesso ao setor financeiro, melhor gestão de recursos humanos e antecipação e influência sobre 
futuras legislações. Portanto, a inclusão crescente da variável climática no planejamento estratégico das indústrias brasileiras é essencial para sua competitividade no médio e longo prazos.

Nesse cenário, a CNI elaborou, em parceria com a Embaixada do Reino Unido no Brasil e a ICF International, um Guia contendo um conjunto de ferramentas para apoiar o empresariado no levantamento de riscos e na identificação das oportunidades relacionadas às mudanças globais do clima no seu ambiente de negócios. Em 2011, foi divulgado um Guia contendo um conjunto de diretrizes para apoiar o empresariado no levantamento de riscos e na identificação das oportunidades relacionadas às mudanças globais do clima no seu ambiente de negócios. O objetivo desta publicação foi agregar valor à estratégia corporativa no desenvolvimento de novos produtos, na melhoria da posição competitiva das empresas e na defesa de sua reputação institucional e empresarial (CNI, 2011).

Para isso, o Guia detalha procedimentos em três fases: diagnóstico; implementação; e divulgação e engajamento. No diagnóstico, há orientações sobre medição de emissões de gases de efeito estufa, considerando as peculiaridades do setor, além de questões fundamentais para se avaliar riscos e oportunidades para as empresas. Na fase de implementação, o Guia explica como colocar em prática políticas e programas, definir metas voluntárias de redução de emissões de gases de efeito estufa e implantar iniciativas de mitigação. Já na etapa de divulgação e engajamento, os gestores recebem dicas de como divulgar as ações a acionistas e outros públicos interessados.

\section{3.}

\section{Importância da construção da matriz de materialidade com engajamento dos principais stakeholders do GMS}

Em trabalho recente sobre o tema, Carpejani et al. (2017) argumentam que muitos pesquisadores e profissionais da área de sustentabilidade não conhecem ou não possuem uma definição clara sobre materialidade. A partir de 2013, a Global Reporting Initiative, por meio de suas Diretrizes G4, fez com que este conceito pudesse ser melhor compreendido, auxiliando as organizações a divulgarem seu desempenho em sustentabilidade, tendo como pontos focais os aspectos materiais mais relevantes, associados aos pilares da sustentabilidade e às necessidades e expectativas de seus stakeholders. 
De fato, o objetivo da GRI, ao incluir o conceito de materialidade na última revisão de suas Diretrizes, foi permitir que os responsáveis pela elaboração e divulgação dos Relatórios de Sustentabilidade pudessem identificar, selecionar e priorizar os tópicos de sustentabilidade mais relevantes para as organizações e seus stakeholders externos.

Como as organizações atuam nos mais diversos ambientes de negócios, tornase necessário identificar o que é mais relevante para ser reportado nos Relatórios de Sustentabilidade, considerando-se as especificidades e expectativas dos stakeholders de seus respectivos contextos socioprodutivos de atuação, além dos impactos em seus próprios negócios (Calabrese et al., 2013; Calabrese et al., 2016).

Conforme o Manual de Implementação das Diretrizes G4 da GRI, a materialidade é definida como o "limiar a partir do qual os aspectos materiais tornam-se suficientemente expressivos para serem relatados. Além desse limiar, nem todos os aspectos materiais têm a mesma importância, pois a ênfase do Relatório de Sustentabilidade deve refletir sua prioridade relativa" (GRI, 2015).

Aspectos materiais são definidos nesta dissertação como aqueles aspectos que impactam significativamente os negócios do GMS segundo os três pilares da sustentabilidade e/ou influenciam substancialmente as avaliações e decisões de stakeholders externos. A ferramenta chave para esta avaliação é a construção da matriz de materialidade composta por dois eixos: (i) significância dos impactos dos aspectos econômicos, ambientais e sociais para o GMS (eixo x da matriz); e (ii) influência nas avaliações e decisões dos stakeholders externos' (eixo y da matriz).

Não obstante a reconhecida importância do engajamento dos stakeholders internos e externos para a análise de materialidade dos aspectos da sustentabilidade, não há indicações específicas nas Diretrizes G4 da GRI sobre como envolver as partes interessadas na construção da matriz de materialidade, com vistas à elaboração do Relatório de Sustentabilidade (Bellantuono et al., 2016).

Nesta pesquisa, a abordagem metodológica para mapeamento e seleção dos stakeholders externos que deverão participar do processo de construção da matriz de materialidade do GMS baseia-se nos trabalhos seminais de Freeman (1984) e de Mitchell, Agle e Wood (1997) e em Freeman et al. (2007).

Freeman et al. (2007) propõem uma classificação para definição dos stakeholders, diferenciando-os em: (i) primários (clientes, colaboradores/funcionários, comunidades, investidores e fornecedores); (ii) 
secundários (órgãos de governo, universidades e instituições de C\&T, mídias, órgãos de defesa do consumidor e outros grupos de interesses especiais).

Nesta pesquisa, incorpora-se a diferenciação dos stakeholders entre primários e secundários, conforme figura 2.1, a seguir.

Nesta figura, as linhas pontilhadas e as setas duplas indicam interconexões bilaterais entre os diversos stakeholders e o GMS, assim como as interações entre os diversos atores do microambiente (stakeholders primários) e do microambiente (stakeholders secundários).

Em complementação à classificação proposta por Freeman et al. (2007), considera-se relevante para a modelagem pretendida a adoção de critérios objetivos para a seleção dos stakeholders externos do GMS, como proposto por Mitchell, Agle e Wood (1997). Segundo esses autores, os critérios são: (i) poder; (ii) legitimidade; e (iii) urgência.

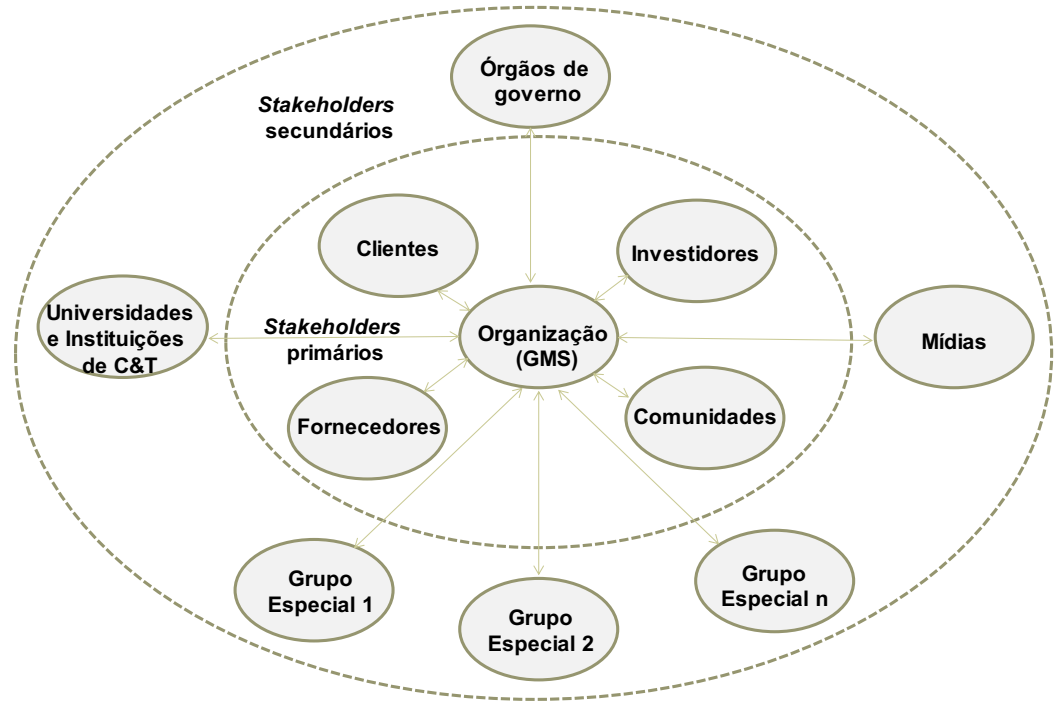

Figura 2.1 - Esquema genérico para mapeamento e classificação dos stakeholders externos

Fonte: Elaboração própria, adaptada de Freeman et al. (2007).

O critério 'poder' está relacionado à obrigação de se fazer algo que não seria feito sem ser solicitado. Segundo Mitchell, Agle e Wood (1997), o poder do stakeholder externo sobre a organização é coercitivo, normativo ou utilitário e associa-se via de regra à detenção de recursos ou informações.

O critério 'legitimidade' é relacionado com a percepção pela organização de que as ações empreendidas pelo stakeholder são desejáveis, apropriadas a um sistema social de normas, valores e crenças. 
Já o critério 'urgência' refere-se à necessidade da velocidade de resposta da organização em relação à demanda do stakeholder.

A abordagem metodológica a ser incorporada à modelagem foco desta pesquisa integra a classificação dos stakeholders em primários e secundários, conforme Freeman et al. (2007), e a aplicação dos três critérios propostos por Mitchell, Agle e Wood (1997) para selecionar em cada grupo de stakeholders aqueles considerados os mais relevantes para participaram da construção da matriz de materialidade do GMS. A esses critérios, associam-se uma escala de três níveis, com a seguinte pontuação para cada representante dos grupos de stakeholders, a saber: baixo (a) - 1 ponto; médio (a) - 3 pontos; e alto (a) - 5 pontos.

$\mathrm{Na}$ prática, os stakeholders com maior pontuação em cada grupo serão priorizados e convidados a participar do processo de construção da matriz de materialidade do GMS, no que se refere às avaliações dos aspectos materiais e sustentabilidade. No capítulo 4, especificamente nas seções 4.1 e 4.2 esse assunto será retomado em maior nível de detalhe.

\section{4. Potencial de aplicação de métodos multicritério para hierarquização e seleção de indicadores de sustentabilidade}

Processos decisórios fazem parte do cotidiano das organizações, muitos deles são consideradas simples ao ponto serem realizados sem a necessidade de uma reflexão mais embasada em indicadores e relatórios específicos.

Os algoritmos que auxiliam na tomada de decisão surgem da necessidade de se lidar com múltiplos critérios para uma avaliação adequada. São conhecidos como métodos multicritério de apoio à decisão (sigla em inglês, MCDM) e caracterizamse pelas matrizes de decisão, compostas de alternativas e critérios ponderados de acordo com os julgamentos de especialistas ou gestores envolvidos em um determinado processo decisório. Há diversos métodos voltados para a busca da melhor alternativa entre um número finito de alternativas, um dos mais eficientes chama-se "Technique for Order Preference by Similarity do Ideal Solution" (TOPSIS). Desenvolvido por Hwang e Yoon (1981) propõe a avaliação de performances de alternativas por meio da similaridade com uma solução ideal, onde a alternativa escolhida deve estar mais distante da solução ideal negativa (NIS) e mais próxima da solução ideal positiva (PIS). 
Método desenvolvido por Saaty (1977; 1990; 1991; 2000), o Analytic Hierarchy Process (AHP) mede fatores intangíveis mediante comparações em pares, por julgamentos de alternativas e critérios segundo uma escala fundamental que varia de 1 a 9, tendo como resultante a definição de prioridades para os fatores mensurados.

Utilizado em processos decisórios a partir da estruturação e um modelo hierárquico com objetivos, critérios/subcritérios e alternativas, compreendendo julgamentos de comparação pareados conforme níveis hierárquicos relacionados. Apresenta a vantagem de aplicação em tangíveis e intangíveis. Por fim, as prioridades de todos os fatores são consolidadas para obtenção da classificação das alternativas. Essas hierarquias simples podem ser estendidas a modelos multinível de decisão, com hierarquias de benefícios, oportunidades, custos e riscos.

Um ponto fundamental é o desafio da medição dos intangíveis, principalmente àqueles que impactam mais fortemente uma organização ou até mesmo a sociedade como um todo. As medições desses intangíveis precedem suas respectivas inclusões como variáveis e devem ser realizadas com envolvimento direto de especialistas envolvidos diretamente nas respectivas situações em questão.

$\mathrm{Na}$ presente pesquisa, será empregado o método AHP para priorização dos aspectos materiais da sustentabilidade que deverão ser considerados pelo GMS para monitorar e avaliar seu desempenho em sustentabilidade.

A aplicação do método deverá ser realizada para cada uma das categorias/subcategorias da estrutura hierárquica GRI, mediante a comparação pareada dos aspectos de cada categoria/subcategoria, segundo duas visões: (i) relevância dos aspectos materiais para os stakeholders externos; e (ii) relevância dos aspectos materiais para o GMS. Como resultado, serão ordenados os aspectos materiais de cada categoria da sustentabilidade por ordem de importância (segundo as duas visões - a externa e a interna).

$\mathrm{Na}$ etapa de seleção e hierarquização dos indicadores e métricas de sustentabilidade, será empregado o método híbrido multicritério AHP-TOPSIS, adotando-se como critérios os vínculos dos indicadores a objetivos estratégicos associados às quatro perspectivas do Balanced Scorecard, a saber: (i) financeira; (ii) clientes/visão externa; (iii) processos; e (iv) aprendizagem e crescimento. A descrição detalhada de ambos os métodos se encontra no apêndice 1. 


\section{5 . \\ Considerações finais sobre o capítulo}

O processo de seleção e envolvimento dos stakeholders é um processo chave na elaboração do Relatório de Sustentabilidade de um GMS. Para tal, sugere-se desdobrar este processo em subprocessos por categoria/subcategoria da sustentabilidade, conforme estrutura das Diretrizes G4 da GRI.

Dada a característica de multissetorialidade do GMS, recomenda-se o envolvimento de stakeholders dos diversos contextos socioprodutivos nos quais o GMS atua. Tão importante quanto o envolvimento de stakeholders especialistas é a mescla com stakeholders generalistas com possam contribuir com uma visão mais integrada para o GMS. Tanto a seleção quanto envolvimento são prerrogativas de cada GMS, a modelagem descrita é uma proposta que permite um relacionamento mais qualitativo entre o GMS e seus stakeholders com objetivo de impacto direto também qualitativo na construção da matriz de materialidade corporativa.

O alinhamento da estratégia com a sustentabilidade corporativa é um ponto fundamental dessa pesquisa. Apresentam-se dois exemplos de GMSs que comprovam impactos positivos em seus respectivos modelos de gestão, são eles: (i) General Eletric; e (ii) Siemens.

Na General Eletric (GE) as unidades globais são: (i) infraestrutura; (ii) saúde e bem estar; (iii) indústrias; (iv) automação financeira; (v) comérco financeiro; e (vi) mídia e entretenimento. A GE tem um Conselho de Diretores responsável pela supervisão da execução da estratégia de sustentabilidade por meio da supervisão das unidades de negócios e do gerenciamento de riscos da GE. O Conselho e seus comitês conduzem inúmeras revisões com as equipes executivas em relação aos aspectos da sustentabilidade de todas as operações. A GE identifica as maiores prioridades de sustentabilidade (materialidade no sentido da Global Reporting Initiative), a partir da avaliação das necessidades do mundo com as partes interessadas e identificando as interseções dessas necessidades com as estratégias de negócios da GE. A estratégia de sustentabilidade e processo de elaboração de relatórios também são alimentados por comentários externos das partes interessadas reunidos por meio de painéis formais de assessoria e envolvimento regular com clientes e empresas parceiras, acadêmicos, associações industriais, ONGs, estrategistas de sustentabilidade e outros parceiros. A GE seleciona questões prioritárias tanto frente a necessidade expressa pelos participantes críticos quanto 
pelo potencial único de impacto das soluções e serviços da GE. Para cada prioridade de sustentabilidade, emplicam a profunda especialização e as tecnologias avançadas da GE visando melhoria dos resultados. A estratégia GE inclui estabelecer metas ambiciosas, desenvolver produtos e soluções que permitam aos clientes atingirem seus objetivos e fazerem parcerias para enfrentarem os desafios que exigem uma abordagem multissetorial. Estimula trabalhos entre grupos internos e partes interessadas externas. A GE monitora o progresso sempre que necessário. Como exemplo de um indicador estratégico da GE apresenta-se a 'água', onde o objetivo estipulado é a redução do uso de água natural em 20\% até 2020 (ano base: 2011), e na medição de 2015 a redução já estava em 17\%. Outro exemplo importante é a veiculação da estratégia GE voltadas para cidadania por meio das seguintes categorias: (i) pessoas (social); (ii) planeta (ambiental) e; (iii) economia (econômica). Na categoria 'pessoas' encontram-se: 'fortalecimento dos funcionários', 'suporte para o sucesso dos clientes GE', 'engajamento com a comunidade' e 'criação de valor para acionistas'. Na categoria 'planeta' encontramse 'escassez de água', 'consumo de energia', 'otimização de recursos' e 'produtos e serviços'. Na categoria 'economia'encontram-se 'governança e compliance', 'políticas públicas', 'sistemas sustentáveis' e 'geração de trabalho'.

No exemplo do GMS Siemens as unidades globais são: (i) energia e gás; (ii) energia eólica e renováveis; (iii) gerenciamento energético; (iv) tenoclogias construtivas; (v) mobilidade; (vi) fábrica digital; (vii) industrias e unidades de processamento; (viii) saúde e bem estar; e (ix) serviços financeiros.

A Siemens orienta sua cadeia de valor pelo mercado, com objetivo claro de captura das oportunidades para seu crescimento sustentável. Os princípios corporativos, objetivos estratégicos e iniciativas de sustentabilidade são categorizados segundo as dimensões da sustentabilidade, expressas em: (i) lucro (profit); (ii) planeta (planet) e; (iii) pessoas (people), que por sua vez, associam-se aos Aspectos Materiais GRI por meio de seus respectivos indicadores.

Apresenta-se, a seguir, um exemplo concreto desse mecanismo de alinhamento. Na dimensão 'lucro', situa-se o tópico 'Contribuições para competitividade dos clientes Siemens com produtos, soluções e serviços', que se associa aos Aspectos Materiais da categoria econômica da GRI 'Desempenho econômico' e 'Presença de mercado'. Na dimensão 'Planeta', situa-se o tópico 'Habilitar clientes Siemens para incrementos voltados para eficiência energética, 
economia de recursos e reduções das amissões de carbono' que por sua vez associase aos Aspectos Materiais da categoria ambiental da GRI 'Energia' e 'Emissões'. Por fim, na dimensão 'pessoas', tem-se 'Contribuição para desenvolvimento sustentável de sociedades com o portfolio Siemens, operações locais e liderança' que se alinha aos Aspectos Materiais das categorias 'econômica' e 'social' da GRI, respectivamente 'Impactos econômicos indiretos' e 'Comunidades'. 


\section{Sistemas de mensuração da sustentabilidade corporativa: índices, indicadores e métricas}

Apresentam-se e analisam-se comparativamente os principais sistemas de mensuração da sustentabilidade corporativa aplicáveis a grupos multissetoriais, particularmente as Diretrizes G4 da Global Reporting Initiative (GRI); a iniciativa Carbon Disclosure Project (CDP); o GHG Protocol; o United Nations Global Compact; e três índices - Dow Jones Sustainability; Carbono Eficiente (ICO2); e Sustentabilidade Empresarial (ISE). A partir da análise comparativa desses referenciais normativos, ao final do capítulo discutem-se as implicações para avaliação de desempenho em sustentabilidade no contexto de grupos multissetoriais.

\section{1.}

Diretrizes G4 da Global Reporting Initiative (GRI)

As Diretrizes GRI para Relato de Sustentabilidade foram criadas pela Global Reporting Initiative (GRI), organização internacional com sede em Amsterdã (Holanda), cuja missão é desenvolver e disseminar globalmente diretrizes para a elaboração de relatórios de sustentabilidade. A ideia de se estabelecer um padrão global para relatórios não-exclusivamente financeiros materializou-se em 1997, mediante uma parceria entre a Coalition for Environmentally Responsible Economy (CERES), instituição não-governamental americana, e o Programa das Nações Unidas para o Meio Ambiente (PNUMA).

A primeira versão das Diretrizes para Relatórios de Sustentabilidade (G1) foi divulgada em 2000, tendo sido elaborada com o engajamento voluntário de diversas partes interessadas em âmbito internacional, envolvendo representantes do setor empresarial, ONGs, organizações trabalhistas, investidores institucionais, ativistas de direitos humanos, firmas de auditoria e consultoria, agências da ONU, entre outras (GRI, 2015). 
O principal propósito da ferramenta é desenvolver e disseminar globalmente diretrizes e incorporar diversos indicadores econômicos, sociais e ambientais na elaboração de relatórios de sustentabilidade.

As Diretrizes encontram-se hoje na quarta versão (G4) e enfatizam ainda mais a necessidade de as organizações concentrarem o processo de elaboração de seus relatórios em tópicos relevantes para suas atividades e também para as principais partes interessadas, mediante a construção prévia da matriz de materialidade. Esse enfoque na materialidade ${ }^{2}$, segundo a GRI (2015), tornará os relatórios mais relevantes, confiáveis e compreensíveis, permitindo que as organizações ofereçam melhores informações a mercados e à sociedade sobre questões relacionadas à sustentabilidade.

A GRI propõe um conjunto de 91 indicadores organizados nas categorias econômica, ambiental e social, sendo esta última subdividida em quatro subcategorias (quadro 3.1). A escolha dos indicadores depende das características e prioridades de cada organização e de suas partes interessadas.

As Diretrizes são apresentadas em duas partes: (i) Princípios para Relato e Conteúdos Padrão; (ii) Manual de Implementação. A primeira parte - Princípios para Relato e Conteúdos Padrão - contém os princípios, conteúdos e critérios a serem aplicados para que a organização elabore seu relatório de sustentabilidade em conformidade com as Diretrizes G4. Inclui ainda definições de termos-chave.

A segunda parte - Manual de Implementação - explica como aplicar os princípios para relato, preparar as informações a serem divulgadas e interpretar os diversos conceitos estabelecidos nas Diretrizes. Contém também referências a outras fontes, um glossário e observações gerais sobre o processo de elaboração do relatório (GRI, 2015).

O quadro 3.1, a seguir, apresenta a estrutura hierárquica das Diretrizes G4 da GRI, compreendendo 3 categorias, 4 subcategorias da categoria social, 46 aspectos materiais e 91 indicadores de sustentabilidade.

No anexo 1, apresentam-se as descrições dos indicadores que integram esta estrutura, conforme Diretrizes G4 da GRI.

\footnotetext{
${ }^{2}$ Aspectos materiais são aqueles que refletem os impactos econômicos, ambientais e sociais significativos da organização ou influenciam substancialmente as avaliações e decisões de representantes das partes interessadas (GRI, 2015).
} 
Quadro 3.1 Estrutura hierárquica das Diretrizes G4 da GRI

\begin{tabular}{|c|c|c|}
\hline Categoria/Subcategoria & Aspectos materiais (AM) segundo Diretrizes G4 & $\begin{array}{l}\text { Indicadores GRI, } \\
\text { segundo Diretrizes } \\
\text { G4 }\end{array}$ \\
\hline \multirow{4}{*}{ Econômica } & AM1 - Desempenho econômico & EC1 a EC4 \\
\hline & AM2 - Presença no mercado & EC5 e EC6 \\
\hline & AM3 - Impactos econômicos indiretos & EC7 e EC8 \\
\hline & AM4 - Práticas de compra & EC9 \\
\hline \multirow[t]{12}{*}{ Ambiental } & AM5 - Materiais & EN1 e EN2 \\
\hline & AM6 - Energia & EN3 a EN7 \\
\hline & AM7 - Água & EN8 a EN10 \\
\hline & AM8 - Biodiversidade & EN11 a EN14 \\
\hline & AM9 - Emissões & EN15 a EN21 \\
\hline & AM10 - Efluentes e resíduos & EN22 a EN26 \\
\hline & AM11 - Produtos e serviços & EN27 e EN28 \\
\hline & AM12 - Conformidade & EN29 \\
\hline & AM13 - Transportes & EN30 \\
\hline & AM14 - Geral & EN31 \\
\hline & AM15 - Avaliação ambiental de fornecedores & EN32 e EN33 \\
\hline & $\begin{array}{l}\text { AM16 - Mecanismos de queixas e reclamações } \\
\text { relacionadas a impactos ambientais }\end{array}$ & EN34 \\
\hline \multirow{8}{*}{$\begin{array}{l}\text { Social/Práticas } \\
\text { trabalhistas e trabalho } \\
\text { decente }\end{array}$} & AM17 - Emprego & LA1 a LA3 \\
\hline & AM18 - Relações trabalhistas & LA4 \\
\hline & AM19 - Saúde e segurança no trabalho & LA5 a LA8 \\
\hline & AM20 - Treinamento e educação & LA9 a LA11 \\
\hline & $\begin{array}{l}\text { AM21 - Diversidade e igualdade de } \\
\text { oportunidades }\end{array}$ & LA12 \\
\hline & $\begin{array}{l}\text { AM22 - Igualdade de remuneração entre homens } \\
\text { e mulheres }\end{array}$ & LA13 \\
\hline & $\begin{array}{l}\text { AM23 - Avaliação de fornecedores em práticas } \\
\text { trabalhistas }\end{array}$ & LA14 e LA15 \\
\hline & $\begin{array}{l}\text { AM24 - Mecanismos de queixas e reclamações } \\
\text { relacionadas a práticas trabalhistas }\end{array}$ & LA16 \\
\hline \multirow{10}{*}{$\begin{array}{l}\text { Social/Direitos } \\
\text { humanos }\end{array}$} & AM25 - Investimento & HR1 e HR2 \\
\hline & AM26 - Não discriminação & HR3 \\
\hline & $\begin{array}{l}\text { AM27 - Liberdade de associação e negociação } \\
\text { coletiva }\end{array}$ & HR4 \\
\hline & AM28 - Trabalho infantil & HR5 \\
\hline & AM29 - Trabalho forçado ou análogo ao escravo & HR6 \\
\hline & AM30 - Práticas de segurança & HR7 \\
\hline & AM31 - Direitos indígenas & HR8 \\
\hline & AM32 - Avaliação & HR9 \\
\hline & $\begin{array}{l}\text { AM33 - Avaliação de fornecedores em direitos } \\
\text { humanos }\end{array}$ & HR10 e HR11 \\
\hline & $\begin{array}{l}\text { AM34 - Mecanismos de queixas e reclamações } \\
\text { relacionadas a direitos humanos }\end{array}$ & HR12 \\
\hline \multirow[t]{7}{*}{ Social/Sociedade } & AM35 - Comunidades locais & SO1 e SO2 \\
\hline & AM36 - Combate à corrupção & $\mathrm{SO} 3$ a SO5 \\
\hline & AM37 - Políticas públicas & SO6 \\
\hline & AM38 - Concorrência desleal & SO7 \\
\hline & AM39 - Conformidade & SO8 \\
\hline & $\begin{array}{l}\text { AM40 - Avaliação de fornecedores em impactos } \\
\text { na sociedade }\end{array}$ & SO9 e SO10 \\
\hline & $\begin{array}{l}\text { AM41 - Mecanismos de queixas e reclamações } \\
\text { relacionadas a impactos na sociedade }\end{array}$ & SO11 \\
\hline \multirow{5}{*}{$\begin{array}{l}\text { Social/Responsabilidade } \\
\text { sobre o produto }\end{array}$} & AM42 - Saúde e segurança do cliente & PR1 e PR2 \\
\hline & AM43 - Rotulagem de produtos e serviços & PR3 a PR5 \\
\hline & AM44 - Comunicações de marketing & PR6 e PR7 \\
\hline & AM45 - Privacidade do cliente & PR8 \\
\hline & AM46 - Conformidade & PR9 \\
\hline $\begin{array}{l}3 \text { categorias } / 4 \\
\text { subcategorias }\end{array}$ & 46 aspectos materiais & 91 indicadores \\
\hline
\end{tabular}

Fonte: Elaboração própria, a partir de GRI (2015). 
Além do exposto, a GRI também fornece dez complementos setoriais orientativos, que trazem orientações específicas para os seguintes setores: (i) operação de aeroportos; (ii) construções e imóveis; (iii) geração, transmissão, distribuição e comercialização de energia elétrica; (iv) organização de eventos; (v) serviços financeiros; (vi) indústria de alimentos; (vii) mídia; (viii) mineração e metalurgia; (ix) organizações não-governamentais; e (x) petróleo e gás.

A GRI afirma que empresas e organizações de diversos setores têm impactos de sustentabilidade específicos, que deverão ser expressos em seus relatórios de sustentabilidade e que não são cobertos pelas Diretrizes G4. Por esta razão, a GRI divulga em sua página institucional 'Desdobramentos Setoriais G4' para empresas e organizações dos setores acima listados, visando aumentar o número e a qualidade dos relatórios e melhorar o desempenho de sustentabilidade nos setores cobertos por essas dez publicações. Cabe ressaltar que até a conclusão da presente pesquisa, a GRI não havia divulgado diretrizes específicas para grupos multissetoriais ou empresas holdings.

Cabe destacar que as Diretrizes G4 incluem quatro diretrizes específicas sobre o engajamento dos stakeholders, oferecendo às organizações uma visão geral desse engajamento no decorrer do período coberto pelo Relatório de Sustentabilidade e não necessariamente limitado apenas para fins da construção da matriz de materialidade e priorização dos aspectos materiais que serão objeto do Relatório.

As diretrizes específicas sobre o engajamento dos stakeholders são:

- G4-24: apresente uma lista de grupos de stakeholders engajados pela organização;

- G4-25: relate a base usada para a identificação e seleção de stakeholders para engajamento;

- G4-26: relate a abordagem adotada pela organização para engajar stakeholders, inclusive a frequência do seu engajamento discriminada por tipo e grupo, com uma indicação de que algum engajamento foi especificamente promovido como parte do processo de preparação do relatório;

- G4-27: relate os principais tópicos e preocupações levantadas durante o engajamento de stakeholders e as medidas adotadas pela organização para abordar esses tópicos e preocupações, inclusive no processo de relatá-las. Relate os grupos de stakeholders que levantaram cada uma das questões e preocupações mencionadas. 


\section{2.}

\section{Carbon Disclosure Project (CDP)}

Carbon Disclosure Project (CDP) é uma organização sem fins lucrativos cujo objetivo é criar uma relação entre acionistas e empresas, focada em oportunidades de negócio decorrentes do aquecimento global e que fornece um completo sistema global de divulgação ambiental. CDP surgiu em 2000, com uma ideia muito simples: pedir às maiores empresas do mundo para compartilhar informação publicamente sobre suas emissões de gases do efeito estufa (GEE) e ações para mitigá-las.

O principal fator de sucesso foi o respaldo da comunidade de investidores, tendo em vista que se coletam essas informações em nome de organizações que detêm ativos financeiros sob gestão, como bancos, fundos de pensão, gestoras de ativos e seguradores. O primeiro pedido de informação sobre mudanças climáticas foi enviado em 2003 às 500 maiores empresas do mundo, segundo o Standard\&Poors.

Em 2015, essa solicitação foi endossada por 822 signatários, que juntos movem US\$ 95 trilhões em ativos. Atualmente, mais de 4.500 organizações de todo o mundo reportam seus dados climáticos ao CDP, que possui o maior volume de informações sobre mudanças climáticas, espaço água e florestas do planeta e procura colocar estes insights na pauta das decisões estratégicas, dos investidores e das decisões políticas.

CDP iniciou suas atividades na América latina em 2006, com a criação de uma listagem local de empresas, a Brasil 80, com base no índice $\mathrm{IBrX}$ da BM\&F BOVESPA. Desde sua primeira edição no Brasil tem o apoio da Associação Brasileira das Entidades Fechadas de Previdência Complementar (ABRAPP) e hoje da Associação Brasileira das Companhias Abertas (ABRASCA), na qualidade de patronos nacionais da iniciativa.

Com a consolidação do CDP como um dos principais instrumentos de divulgação de iniciativas relacionadas ao gerenciamento do carbono, e com o aumento da demanda por dados do CDP, em 2010 foi lançado um índice de desempenho, o Carbon Performance Leadership Index (CPLI), que identifica as empresas que exibem liderança com relação à gestão dos riscos impostos pelas mudanças do clima. Além deste, outros dois índices foram lançados como produtos baseados nas informações do CDP: (i) FTSE CDP Carbon Strategy Index Series; 
(ii) Market Carbon Disclosure Leadership Index que expõem aos investidores as corporações melhores posicionadas na corrida para a nova economia de baixo carbono.

\section{3.}

\section{GHG Protocol}

O GreenHouse Gas Protocol (GHG Protocol) foi desenvolvido no ano 2001 pelo World Business Council for Sustainable Development (WBCSD) e pelo World Resources Institute (WRI) que tem como meta o estabelecimento de bases para a contabilização de Gases do Efeito Estufa (GEE). Os objetivos de mensuração dos sistemas/índices do GHG Protocol estão voltados para o estímulo da cultura corporativa para a elaboração e publicação de inventários de emissões de gases do efeito estufa, proporcionando aos participantes o acesso a instrumentos e padrões de qualidade internacional.

Nasce da colaboração multilateral entre empresas, organizações não governamentais e governos (WRI, 2004). Consiste em um marco metodológico geral que fornece dicas de trabalho para a determinação de ferramentas de cálculo dos GEE. O Protocolo é reconhecido mundialmente e aparece como principal referencia junto com a Norma ISO 14064.

Várias atualizações têm sido feitas desde seu início, como nos anos 2004 e 2008. The Corporate Value Chain (Escopo 3) e Product Life Cycle Accounting and Reporting Standards foram publicados em outubro de 2011, após um processo de desenvolvimento multistakeholders de três anos. Estas novas normas incluem requisitos e orientações sobre o cálculo e a contabilidade do ciclo de vida do produto e o relatório das emissões Escopo 3 da organização, ou seja, as emissões indiretas das corporações, além dos já contabilizados no Escopo 2 a partir da geração de energia comprada. Estas duas novas normas são baseadas na abordagem do ciclo de vida. O Escopo 3 é um suplemento para o Corporate Standard, enquanto o Product Standard baseia-se na série ISO 14040 de Normas.

O Programa Brasileiro GHG Protocol iniciou-se no ano 2008 e tem como objetivo estimular a cultura corporativa para a elaboração e publicação de inventários de emissões de GEE, proporcionando aos participantes acesso a instrumentos e padrões de qualidade internacional. A aplicação do método $G H G$ Protocol no Brasil acontece de forma adaptada ao contexto nacional (Programa Brasileiro GHG Protocol, 2018). 
O Programa Brasileiro organiza grupos de trabalho, junto às empresas participantes, para o aperfeiçoamento do método e desenvolvimento de novas ferramentas para a contabilização de emissões de GEE de acordo com a realidade brasileira. Além dos grupos de trabalho, oficinas para elaboração dos inventários de GEE e apoio técnico serem oferecidos apenas para as empresas participantes do Programa Brasileiro GHG Protocol, o método e suas atualizações estão disponíveis nas publicações e no website para uso de qualquer organização que tenha interesse.

Uma das iniciativas de destaque do Programa Brasileiro, considerada pioneira em todo o mundo, foi a criação do Registro Público de Emissões e da área pública para consulta dos inventários das empresas e de estatísticas por setor.

Para a realização dos inventários corporativos, o GHG Protocol estabelece seis passos básicos: (i) definir limites organizacionais do inventário; (ii) definir limites operacionais do inventário; (iii) selecionar metodologia de cálculo e fatores de emissão; (iv) coletar dados das atividades que resultam na emissão de GEE; (v) calcular as emissões; e (vi) elaborar o relatório de emissões de GEE.

\section{4 .}

\section{United Nations Global Compact}

A missão do Global Compact das Organizações das Nações Unidas (UN) busca mobilizar um movimento global de empresas e partes interessadas sustentáveis para criar o mundo que queremos. Para que isso aconteça, apoia as empresas para: (i) fazer negócios de forma responsável, alinhando suas estratégias e operações com os dez princípios sobre direitos humanos, trabalho, meio ambiente e anticorrupção; (ii) realizar ações estratégicas para avançar metas sociais mais amplas, como os Objetivos de Desenvolvimento Sustentável da UN, com ênfase na colaboração e na inovação.

Dentre os dez princípios do United Nations Global Compact, a sustentabilidade corporativa começa com o sistema de valores de uma empresa e uma abordagem baseada em princípios para fazer negócios. Isso significa, no mínimo, operar voltada para o cumprimento de responsabilidades fundamentais nas áreas de direitos humanos, trabalho, meio ambiente e anticorrupção. Ao incorporar os 10 princípios do Global Compact em estratégias, políticas e procedimentos, e estabelecer uma cultura de integridade, as empresas não são apenas responsáveis pelas suas responsabilidades básicas para pessoas e para o planeta, mas também preparam o terreno para o sucesso a longo prazo. 
Os dez princípios do Global Compact são derivados da Declaração Universal dos Direitos Humanos, da Declaração da Organização Internacional do Trabalho sobre os Princípios e Direitos Fundamentais no Trabalho, da Declaração do Rio sobre Meio Ambiente e Desenvolvimento e da Convenção das Nações Unidas contra a Corrupção. São eles:

- Direitos Humanos: Princípio 1: as empresas devem apoiar e respeitar a proteção dos direitos humanos proclamados internacionalmente; e Princípio 2: certifique-se de que eles não são cúmplices de abusos de direitos humanos;

- Trabalho: Princípio 3: as empresas devem manter a liberdade de associação e o reconhecimento efetivo do direito à negociação coletiva; Princípio 4: a eliminação de todas as formas de trabalho forçado e compulsório; Princípio 5: abolição efetiva do trabalho infantil; e Princípio 6: a eliminação da discriminação em matéria de emprego e ocupação;

- Meio Ambiente: Princípio 7: as empresas devem apoiar uma abordagem preventiva dos desafios ambientais; Princípio 8: empreender iniciativas para promover uma maior responsabilidade ambiental; e Princípio 9: incentivar o desenvolvimento e a difusão de tecnologias ecológicas;

- Anticorrupção: Princípio 10: As empresas devem trabalhar contra a corrupção em todas as suas formas, incluindo a extorsão e o suborno.

\section{5 .}

\section{Dow Jones Sustainability Index}

Criado em 1999, é um índice mundial de benchmarking da Dow Jones \& Company constituído por empresas que atuam a partir de uma perspectiva de desenvolvimento sustentável.

O Dow Jones Sustainability Index é revisado anualmente como resultado de processo de consulta às 2.500 empresas com maior valor de capitalização free-float, ranqueadas no Dow Jones Global Index - DJGI de 31 de dezembro do ano anterior.

As empresas consultadas respondem a um questionário, em que terão que evidenciar que sua busca pelo resultado econômico leva em consideração preocupações sobre aspectos ambientais e sociais e seus impactos. As respostas ao questionário com questões relacionadas às dimensões econômica, social e ambiental são avaliadas e auditadas por organização suíça denominada SAM Sustainable Asset Management Research. 
Todos os anos, pergunta-se para mais de 3.400 empresas listadas em todo o mundo entre 80-120 questões específicas do setor, com foco em fatores econômicos, ambientais e sociais que são relevantes para o sucesso das organizações, mas que são sub-pesquisados em análises financeiras convencionais. Esses dados, combinados com os objetivos de sustentabilidade e risco/retorno dos investidores, são usados para produzir uma família de índices, incluindo índices globais, subíndices e produtos inovadores, como os índices ESG (environmental, social and governance).

Os índices ESG baseiam-se na base de dados ESG da RobecoSAM, cobrindo mais de 600 indicadores para mais de 4.000 empresas globais. O S\&P Dow Jones Indices é o parceiro estratégico para a publicação e cálculo dos índices ESG.

A estrutura do questionário é composta das seguintes seções:

- Introdução: dados cadastrais da organização e do responsável pelo preenchimento, além de respostas corporativas gerais e introdutórias sobre a organização;

- Dimensão econômica: governança; materialidade; gerenciamento de risco e crises; código de conduta nos negócios (inclui práticas anticorrupção); gerenciamento da relação com consumidores/clientes; influência política; gestão da marca; estratégia tributária; mensuração e avaliação de impacto; informações de segurança e cybersegurança; proteção e privacidade;

- Dimensão ambiental: relatórios ambientais; políticas ambientais \& sistemas de gestão; ecoeficência operacional (emissões diretas GHG escopo 1 / emissões indiretas GHG - escopo 2 / energia / água / lixo);

- Dimensão social: relatórios sociais; indicadores de práticas laborais; direitos humanos; desenvolvimento do capital humano; atração \& retenção de talentos; cidadania \& filantropia corporativa; saúde \& segurança ocupacional; engajamento dos stakeholders; (v) uma parte final relacionada ao feedback sobre a pesquisa (não obrigatória e não faz parte da avaliação).

A próxima geração de pontuações do ESG deixará de lado as metodologias convencionais de pontuação que já não se encaixam nos modelos de fatores tradicionais e normalmente resultam em desvios por porte organizacional ou diferenças marcantes regionais. 
As grandes organizações capitalizadas tendem a ter melhores processos e divulgações de sustentabilidade corporativa do que as empresas menores, e as empresas europeias tendem a ser mais transparentes. Como resultado, essas empresas tendem a receber pontuações ESG mais altas. Além disso, em contraste com os principais fatores, como valor ou momento, as pontuações ESG tradicionais são amplas, geralmente agregando centenas de indicadores individuais em uma única pontuação, diluindo informações financeiras de maneira significativa. Para enfrentar esses desafios, a metodologia existente foi construída para desenvolver pontuações de fatores ESG imparciais e financeiramente materiais que são mais relevantes para os investidores.

A nova metodologia Smart ESG aproveita a riqueza de um banco de dados de sustentabilidade para identificar os critérios da sustentabilidade mais relevantes do ponto de vista financeiro, fim de se desenvolver um fator ESG que possa ser combinado com outros fatores financeiros comuns.

A nova metodologia objetiva: (i) remover preconceitos (setoriais, regionais, portes) com geração de scores sem preconceitos; (ii) combinação de visão de futuro com evidências passadas otimizado para que os critérios mais relevantes financeiramente sejam superponderados em relação àqueles que tiveram um impacto mínimo no desempenho financeiro, aprimorando o foco na materialidade financeira; (iii) fatores neutralizantes, como etapa final, remover quaisquer exposições não intencionais a fatores financeiros comuns, isso permite isolar um fator da sustentabilidade quantitativo que pode ser combinado com outros fatores comuns em uma carteira de investimentos. As pontuações dos fatores ESG resultantes são pontuações imparciais, baseadas em evidências, com um perfil de retorno de risco atraente e baixa correlação com fatores de investimento que permite incluir a sustentabilidade em um modelo de fator tradicional e medir o quanto a exposição de determinado portfólio tem para a sustentabilidade, bem como sua contribuição para o risco e o retorno do portfólio.

\section{6.}

\section{Índice Carbono Eficiente (ICO2)}

O Índice de Carbono Eficiente (ICO2) foi criado em 2010 pela Bolsa de Valores, Mercadoria e Futuros de São Paulo (BM\&FBOVESPA) em conjunto com o Banco Nacional de Desenvolvimento Econômico e Social (BNDES). 
Esse índice que é composto pelas ações das companhias participantes do índice IBrX-50 que aceitaram participar dessa iniciativa, adotando práticas transparentes com relação a suas emissões de gases do efeito estufa (GEE), leva em consideração para ponderação das ações das empresas componentes seu grau de eficiência de emissões de GEE, além do total de ações em circulação (free-float) de cada uma delas.

Além disso, o ICO2 visa prover o mercado com um indicador cuja performance é a resultante de um portfólio balizado por fatores que incorporam questões relacionadas às mudanças climáticas. Portanto, o índice ICO2 objetiva representar a importância do tema Responsabilidade Social e Ambiental para a sociedade, mostrando e valorizando as empresas que investem em sustentabilidade.

Os critérios de inclusão são: (i) pertencer à carteira do IBrX 50; (ii) ter aderido formalmente à iniciativa do ICO2; (iii) reportar dados de seu inventário anual de GEE de acordo com o nível de abrangência e prazo definidos pela BM\&FBovespa.

Já os critérios de exclusão são: (i) deixar de atender a qualquer um dos critérios de inclusão acima indicados; (ii) durante a vigência da carteira a ser listado em situação especial, isto é, se um ativo pertencente ao índice passar a ser negociado em situação especial (recuperação judicial ou extrajudicial, regime especial de administração temporária, intervenção ou qualquer outra hipótese definida pela BM\&FBovespa). Companhias que estiverem em situação especial ou que estiverem sujeitas a prolongado período de suspensão de negociação não serão elegíveis para os índices.

A Ponderação do ICO2 é baseada no peso de cada ação no Índice Carbono Eficiente levará em consideração dois aspectos: (i) participação no IBrX 50, no qual os ativos são ponderados pelo valor de mercado do free-float da espécie pertencente à carteira, com limite de participação baseado na liquidez; (ii) razão entre as emissões de GEE informadas no Inventário de Emissões de GEE para o ano-base, medidas em toneladas de $\mathrm{CO} 2$ equivalente $(\mathrm{tCO} 2 \mathrm{e})$, e a receita bruta reportada nas demonstrações financeiras padronizadas apresentadas no Brasil relativas ao mesmo ano-base (Coeficiente Emissão/Receita ou Coeficiente).

A proposta é que o ICO2 seja um instrumento econômico de incentivo à adoção de práticas de gestão ambiental com foco em Mudanças Climáticas, onde as organizações serão incentivadas a mensurarem, gerirem e reportarem suas emissões de GEE de maneira transparente para acionistas e mercado, além de 
gerarem oportunidades de investimentos para investidores preocupados com aspectos ambientais.

\section{7. \\ Índice de Sustentabilidade Empresarial (ISE)}

O Índice de Sustentabilidade Empresarial (ISE) foi lançado em 2005 pela Bolsa de Valores, Mercadorias e Futuros (BM\&FBOVESPA), em parceria com a Associação Brasileira das Entidades Fechadas de Previdência Complementar (ABRAPP), Associação Nacional dos Bancos de Investimento (ANBID), Associação dos Analistas e Profissionais de Investimentos do Mercado de Capitais (APIMEC), Instituto Brasileiro de Governança Corporativa (IBGC), International Finance Corporation (IFC), Instituto Ethos e Ministério do Meio Ambiente (MMA). Acompanhou a tendência mundial voltada para investimentos focados em ativos que incorporem conceitos de responsabilidade social e sustentabilidade corporativa.

O ISE é um indicador que agrupa empresas com desempenho econômico financeiro relevante associado às ações de sustentabilidade social e ambiental. Segundo a BM\&FBOVESPA, o objetivo é refletir o retorno de uma carteira composta por ações de empresas com reconhecido comprometimento com a responsabilidade social e a sustentabilidade empresarial, bem como atuar como impulsionador das boas práticas no ambiente empresarial brasileiro.

A seleção da carteira de no máximo 40 ações é feita anualmente por meio das respostas aos questionários que são enviados às empresas pré-selecionadas (que estejam entre as empresas com as 200 ações mais negociadas nos últimos 12 meses que precedem a avaliação e que tenham sido negociadas pelo menos em $50 \%$ dos pregões realizados no mesmo período). Um Conselho escolhe as empresas com melhores classificações nas dimensões: (i) geral; (ii) natureza do produto; (iii) governança corporativa; (iv) econômico-financeira; (v) social; (vi) ambiental; (viii) mudanças climáticas. No tocante às Mudanças Climáticas, em 2010 o questionário passou a incluir indicadores em quatro critérios: (i) política da empresa; (ii) gestão; (iii) desempenho; (iv) comunicação.

A décima terceira carteira do Índice de Sustentabilidade Empresarial (ISE) que vigora de 02 de janeiro de 2018 até 04 de janeiro de 2019 reúne 33 ações de 30 companhias, representa 12 setores e soma R \$ 1,28 trilhão (aproximadamente US\$ 0,38 bilhão de dólares americanos pela cotação de 09/abril/2018) em valor de 
mercado. Esse montante equivale a $41,47 \%$ do total do valor das companhias com ações negociadas na B3, com base no fechamento de 21/11/2017.

Para o processo de construção desta carteira foram convidadas 179 companhias, emissoras das 200 ações mais líquidas. Destas, 41 se inscreveram no processo, sendo 37 Elegíveis. A nova carteira (período 2018-2019) é composta pelas seguintes ações: AES Tiete; B2W; Banco do Brasil; Bradesco; Braskem; CCR; Celesc; Cemig; Cielo; Copel; CPFL; Duratex; Ecorodovias; EDP; Eletropaulo; Engie; Fibria; Fleury; Itaú Unibanco; Itaúsa; Klabin; Light; Lojas Americanas; Lojas Renner; MRV; Natura; Santander; Telefônica; Tim; Weg.

Desde a sua criação, em 2005, o ISE apresentou rentabilidade de $+185,01 \%$ contra $+113,72 \%$ do Ibovespa (base de fechamento em 21/11/2017). No mesmo período, o ISE teve ainda menor volatilidade: $24,67 \%$ em relação a $27,46 \%$ do Ibovespa.

\section{8.}

\section{Análise comparativa dos sistemas de mensuração da sustentabilidade abordados}

Com base nas características dos sistemas de mensuração da sustentabilidade abordados neste capítulo e adotando-se os critérios propostos por Van Bellen (2002, 2005) para análise e comparação entre diferentes sistemas, apresenta-se nesta seção um quadro comparativo dos sistemas analisados: (i) Diretrizes G4 da GRI; (ii) Carbon Disclosure Project (CDP); (iii) GHG Protocol (GHG); (iv) United Nations Global Compact. (iv) Dow Jones Sustainability Index; (v) Índice de Carbono Eficiente (ICO2); e (vi) Índice de Sustentabilidade Empresarial (ISE).

Os critérios propostos por Van Bellen $(2002 ; 2005)$ são descritos no quadro 3.2, a seguir. Já os quadros 3.3 e 3.4 apresentam os resultados da análise comparativa dos sistemas abordados neste capítulo, como pano de fundo para a discussão sobre as implicações para avaliação de desempenho em sustentabilidade no contexto de grupos multissetoriais.

Como pode ser observado no quadro 3.2 , todos os sistemas cobrem aspectos ambientais e econômicos quanto ao escopo, porém o Global Compact e o ISE também abordam aspectos sociais e institucionais. Cabe ressaltar que o ISE aborda ainda governança corporativa. 
Quadro 3.2 - Critérios para comparação dos sistemas de mensuração da sustentabilidade corporativa

\begin{tabular}{|l|l|}
\hline Critério & Itens a serem analisados \\
\hline Escopo & $\begin{array}{l}\text { Dimensões da sustentabilidade corporativa abordadas (econômica, social, } \\
\text { ambiental e institucional). }\end{array}$ \\
\hline Esfera & $\begin{array}{l}\text { Unidade foco da análise: globo, continente, país, região, localidade, organização } \\
\text { ou indivíduo). }\end{array}$ \\
\hline $\begin{array}{l}\text { Tipo e nível de } \\
\text { agregação dos dados }\end{array}$ & $\begin{array}{l}\text { Quanto ao tipo: qualitativos, quantitativos ou ambos. } \\
\text { Quanto ao nível de agregação: índices, subíndices, indicadores, dados } \\
\text { analisados. }\end{array}$ \\
\hline Participação & $\begin{array}{l}\text { Top-down, quando concebido por especialistas; bottom-up, quando concebido } \\
\text { com a participação dos públicos-alvo; e mista. }\end{array}$ \\
\hline \multirow{7}{*}{ Interface } & $\begin{array}{l}\text { Complexidade: do ponto de vista dos usuários, complexidade dos cálculos dos } \\
\text { indicadores, subíndices e índices. }\end{array}$ \\
\cline { 2 - 2 } & $\begin{array}{l}\text { Apresentação dos resultados: utilização de índice geral, recursos visuais (gráficos } \\
\text { e uso de cores, por exemplo), recursos adicionais. }\end{array}$ \\
\cline { 2 - 2 } & $\begin{array}{l}\text { Abertura: possibilidade de observação dos índices agregados somente ou } \\
\text { apresentação os índices e seus componentes, de forma desagregada. }\end{array}$ \\
\cline { 2 - 2 } & $\begin{array}{l}\text { Potencial educativo: capacidade de representar para o público os aspectos } \\
\text { materiais da sustentabilidade e seus impactos para seus negócios, a sociedade e } \\
\text { o meio ambiente. }\end{array}$ \\
\hline
\end{tabular}

Fonte: Adaptação de Van Bellen (2002; 2005).

Quanto à esfera, todos voltam-se para as organizações. Observações apenas se fazem quanto ao CDP, com abrangência local, e ao Global Compact, com abrangência global. Em relação à agregação dos dados, todos os sistemas apresentam dados primários, dados analisados e indicadores. Ressalva somente para o ISE, em que os indicadores são oriundos das respostas dos questionários pelas organizações participantes. O GHG Protocol apresenta subindicadores e o ICO2 subíndices e índices. O ISE também apresenta índices.

No tocante à complexidade, pode-se considerar que o CDP e o Global Compact são de elevada complexidade, enquanto GHG, ICO2 e ISE são de baixa complexidade. 
Quadro 3.3 - Sistemas de mensuração da sustentabilidade corporativa analisados quanto ao escopo, abrangência e nível de agregação dos dados

\begin{tabular}{|c|c|c|c|c|c|c|c|c|c|c|c|c|c|c|c|c|}
\hline \multirow{2}{*}{$\begin{array}{c}\text { Sistema de } \\
\text { mensuração da } \\
\text { sustentabilidade } \\
\text { corporativa }\end{array}$} & \multicolumn{4}{|c|}{ Escopo (dimensões) } & \multicolumn{6}{|c|}{ Abrangência (unidade foco de análise) } & \multicolumn{6}{|c|}{ Nível de agregação dos dados } \\
\hline & Ambiental & Social & Econômico & Institucional & Global & Continental & Nacional & Regional & Local & Organizacional & \begin{tabular}{|c|}
$\begin{array}{c}\text { Dados } \\
\text { primários }\end{array}$ \\
\end{tabular} & $\begin{array}{c}\text { Dados } \\
\text { analisados }\end{array}$ & $\begin{array}{c}\text { Sub- } \\
\text { indicadores }\end{array}$ & Indicadores & Subíndices & Índices \\
\hline $\begin{array}{l}\text { Diretrizes G4 da } \\
\text { Global Reporting } \\
\text { Initiative (GRI) }\end{array}$ & $x$ & $x$ & $x$ & $x$ & & & & & & $x$ & $x$ & $x$ & & $x$ & & \\
\hline $\begin{array}{l}\text { Carbon } \\
\text { Disclosure } \\
\text { Project (CDP) }\end{array}$ & $x$ & & $x$ & & & & & & $x$ & $x$ & $x$ & $x$ & & $x$ & & \\
\hline GHG Protocol & $\mathrm{x}$ & & & & & & & & & $x$ & $x$ & $x$ & $x$ & $\mathrm{x}$ & & \\
\hline $\begin{array}{l}\text { United Nations } \\
\text { Global Compact }\end{array}$ & $\mathrm{x}$ & $x$ & $x$ & $x$ & $\mathrm{x}$ & & & & & $\mathrm{x}$ & $x$ & $x$ & & $x$ & & \\
\hline $\begin{array}{l}\text { Dow Jones } \\
\text { Sustainability } \\
\text { Index }\end{array}$ & $x$ & $x$ & $x$ & & & & & & & $x$ & $x$ & $x$ & & $x$ & & \\
\hline $\begin{array}{l}\text { Índice Carbono } \\
\text { Eficiente (ICO2) }\end{array}$ & $x$ & & $\mathrm{x}$ & & & & & & & $\begin{array}{l}x \text { (carteira das } \\
\text { empresas) }\end{array}$ & $x$ & $\mathrm{x}$ & & $\mathrm{x}$ & & \\
\hline $\begin{array}{l}\text { Índice de } \\
\text { Sustentabilidade } \\
\text { Empresarial (ISE) }\end{array}$ & $\begin{array}{c}\mathrm{x} \\
\text { (mudanças } \\
\text { climáticas, } \\
\text { como } \\
\text { dimensão } \\
\text { à parte) }\end{array}$ & $\mathrm{x}$ & $\mathrm{x}$ & $\begin{array}{c}\mathrm{x} \\
\text { (governança } \\
\text { corporativa) }\end{array}$ & & & & & & $\begin{array}{l}x \text { (carteira das } \\
\text { empresas) }\end{array}$ & $x$ & $\mathrm{x}$ & & $\begin{array}{c}x \text { (relativo às } \\
\text { respostas dos } \\
\text { questionários) }\end{array}$ & & \\
\hline
\end{tabular}

Fonte: Elaboração própria, adotando-se os critérios de Van Bellen (2002; 2005). 
Quadro 3.4 - Sistemas de mensuração da sustentabilidade corporativa analisados quanto ao nível de participação e à interface

\begin{tabular}{|c|c|c|c|c|c|c|c|c|c|c|c|c|c|c|c|c|}
\hline \multirow{2}{*}{\begin{tabular}{l}
\multicolumn{1}{c}{ Sistema de } \\
mensuração da \\
sustentabilidade \\
corporativa
\end{tabular}} & \multicolumn{3}{|c|}{ Nível de participação } & \multicolumn{3}{|c|}{$\begin{array}{c}\text { Interface: } \\
\text { complexidade }\end{array}$} & \multicolumn{3}{|c|}{ Interface: apresentação dos resultados } & \multicolumn{5}{|c|}{ Interface: abertura das informações } & \multicolumn{2}{|c|}{ Interface: potencial educativo } \\
\hline & $\begin{array}{c}\text { Top } \\
\text { down }\end{array}$ & Mista & $\begin{array}{c}\text { Bottom } \\
\text { up }\end{array}$ & Alta & Média & Baixa & $\begin{array}{c}\text { Índice } \\
\text { geral }\end{array}$ & $\begin{array}{c}\text { Recursos } \\
\text { visuais }\end{array}$ & $\begin{array}{c}\text { Recursos } \\
\text { adicionais (quais) }\end{array}$ & Índice & \begin{tabular}{|c|} 
Sub- \\
indices
\end{tabular} & Indicadores & \begin{tabular}{|c|} 
Sub- \\
indicadores \\
\end{tabular} & \begin{tabular}{|c|} 
Dados \\
analisados
\end{tabular} & Pontos fortes & $\begin{array}{c}\text { Ponto para } \\
\text { melhoria }\end{array}$ \\
\hline $\begin{array}{l}\text { Diretrizes G4 da } \\
\text { Global Reporting } \\
\text { Initiative (GRI) }\end{array}$ & & $x$ & & & $x$ & & & & $\begin{array}{l}\text { Ênfase na matriz } \\
\text { de materialidade }\end{array}$ & & & $x$ & & $x$ & $\begin{array}{l}\text { Comparabilidade } \\
\text { Suplementos } \\
\text { setoriais }\end{array}$ & \begin{tabular}{|l|} 
Não enfatiza \\
enfoque \\
multissetorial. \\
Falta orientação \\
metodológica \\
para seleção dos \\
stakeholders
\end{tabular} \\
\hline $\begin{array}{l}\text { Carbon } \\
\text { Disclosure } \\
\text { Project (CDP) }\end{array}$ & $x$ & & & $x$ & & & $x$ & $\mathrm{x}$ & & & & $x$ & & $x$ & \begin{tabular}{|l|} 
Incentivo às boas \\
práticas de \\
gestão \\
ambiental; \\
centralização de \\
informações e \\
dados \\
\end{tabular} & $\begin{array}{l}\text { Dificuldade de } \\
\text { acesso aos } \\
\text { questionários }\end{array}$ \\
\hline GHG Protocol & $x$ & & & & $x$ & & $\mathrm{x}$ & $\begin{array}{l}\text { Uma faixa } \\
\text { para cada } \\
\text { dimensão }\end{array}$ & $\begin{array}{c}\text { Análise das } \\
\text { categorias por } \\
\text { dimensão }\end{array}$ & & & $x$ & $x$ & & \begin{tabular}{|l|} 
Facilidade de uso \\
e utilidade. \\
Acreditação \\
internacional. \\
\end{tabular} & \begin{tabular}{|l|} 
Dificuldade na \\
medição dos GEE \\
para escopo 3
\end{tabular} \\
\hline $\begin{array}{l}\text { Dow Jones } \\
\text { Sustainability } \\
\text { Index }\end{array}$ & $x$ & & & & & $x$ & & & $\begin{array}{l}\text { Emissão de } \\
\text { relatório com as } \\
\text { repostas ao } \\
\text { questionário }\end{array}$ & $x$ & $x$ & & & & $\begin{array}{l}\text { Ferramenta para } \\
\text { gestores } \\
\text { corporativos }\end{array}$ & $\begin{array}{l}\text { Volatilidade da } \\
\text { carteira; entrada } \\
\text { e saída de } \\
\text { empresas. }\end{array}$ \\
\hline $\begin{array}{l}\text { Índice Carbono } \\
\text { Eficiente (ICO2) }\end{array}$ & $x$ & & & & $x$ & & $x$ & $x$ & & $x$ & $x$ & $x$ & & $x$ & $\begin{array}{l}\text { Conscientização } \\
\text { sobre as } \\
\text { emissões }\end{array}$ & $\begin{array}{l}\text { Volatilidade da } \\
\text { carteira; entrada } \\
\text { e saída de } \\
\text { empresas; } \\
\text { complexidade } \\
\text { dos cálculos }\end{array}$ \\
\hline $\begin{array}{l}\text { Índice de } \\
\text { Sustentabilidade } \\
\text { Empresarial (ISE) }\end{array}$ & $x$ & & & & $x$ & & $x$ & $x$ & $\begin{array}{c}\text { Relatórios e } \\
\text { análise online. }\end{array}$ & $x$ & & & & & $\begin{array}{l}\text { Questionário em } \\
\text { constante } \\
\text { aperfeiçoamento }\end{array}$ & $\begin{array}{l}\text { Correlação entre } \\
\text { desempenho } \\
\text { sustentável } \\
\text { versus } \\
\text { econômico- } \\
\text { financeiro frágil. }\end{array}$ \\
\hline $\begin{array}{l}\text { UN Global } \\
\text { Compact }\end{array}$ & $x$ & & & $x$ & & & & $x$ & $\begin{array}{l}\text { Formato objetivo } \\
\text { para melhor } \\
\text { comunicação }\end{array}$ & & & $x$ & & $x$ & $\begin{array}{l}\text { Permite definir } \\
\text { objetivos claros e } \\
\text { planos de ação. }\end{array}$ & $\begin{array}{l}\text { Dificuldade em } \\
\text { obter os dados } \\
\text { em função do } \\
\text { detalhamento } \\
\text { requerido. }\end{array}$ \\
\hline
\end{tabular}

Fonte: Elaboração própria, adotando-se os critérios de Van Bellen (2002; 2005) 
Quanto à participação, todos são top-down, ou seja, é um processo que parte da alta administração e a partir da mesma dissemina-se pela empresa. No que se refere à apresentação dos resultados, o Global Compact é o único que não apresenta um índice numérico geral. CPD e ICO2 não utilizam recursos adicionais. Todos os sistemas utilizam-se de recursos visuais, conforme mostrado no quadro 3.4.

No que se refere à abertura, somente o ISE não utiliza indicadores. Somente o GHG Protocol utiliza subindicadores, sendo um para cada gás de efeito estufa. CDP, ICO2 e Global Compact utilizam dados analisados. ICO2 e ISE utilizam índices, e o ICO2 também utiliza subíndices.

Finalmente, em relação ao potencial educativo, os pontos fortes sobressaemse sobre os pontos fracos pesquisados. Isso é muito importante pois aumenta a atratividade, fazendo com que aumente o número de organizações que utilizam um dos sistemas abordados.

Cabe ressaltar ainda que a complexidade impacta diretamente no potencial educativo, podendo ser uma importante barreira para a adoção, além dos custos envolvidos também serem maiores na grande maioria dos casos. No tocante às dificuldades, que podem ser traduzidas em pontos fracos, observam-se exemplos como dificuldade na obtenção de dados ou no acesso aos questionários-base, permissão de autoavaliação, alta volatilidade das carteiras que compõem os respectivos índices, dentre outras.

\section{9 .}

\section{Implicações para avaliação de desempenho em sustentabilidade no contexto de grupos multissetoriais}

A principal implicação para avaliação de desempenho em grupos multissetoriais é a compreensão do próprio caráter da multissetorialidade inerente aos mesmos. As características e peculiaridades de cada setor tornam a avaliação de desempenho bem mais específica. Além disto, cada setor em que o GMS atua representa uma parte de sua história, tem um peso nos seus resultados presentes e, ainda mais relevante, está presente no planejamento estratégico com visões e impactos diferentes no médio e longo prazo. No caso dos GMSs, a padronização simplifica os processos envolvidos em todas as etapas, mas traz consigo incertezas de medição que podem induzir decisores à realização de avaliações incompletas e/ou distorcidas e, consequentemente, à tomada de decisões equivocadas. 
Outra implicação fundamental é que, por mais generalistas e aplicáveis que sejam as normas e diretrizes existentes, há lacunas importantes no tocante à avaliação de desempenho dos grupos multissetoriais. Um mesmo valor encontrado para um determinado indicador em duas ou mais empresas, por exemplo, que façam parte do mesmo GMS, não significa que automaticamente leve ao mesmo valor no nível corporativo. $\mathrm{O}$ valor pode indicar um desempenho igual ou semelhante, mas na verdade pode impactar de maneira diferente o desempenho de um GMS, sendo recomendável que se avalie como deve ser interpretado dentro do próprio contexto do mesmo.

Considerando-se o exposto e os resultados dos quadros 3.3. e 3.4, conclui-se que as Diretrizes G4 da GRI constituem o referencial normativo mais adequado a ser aplicado pelas empresas holdings e por grupos multissetoriais para mensuração da sustentabilidade corporativa. 


\section{4 \\ Modelo conceitual para monitoramento e avaliação de desempenho em sustentabilidade de grupos multissetoriais}

Propõe-se um modelo conceitual para monitoramento e avaliação do desempenho da sustentabilidade corporativa de grupos multissetoriais, ressaltandose os diferenciais deste modelo em relação às práticas atuais. $\mathrm{O}$ modelo compreende cinco etapas e foi desenvolvido para aplicação no nível corporativo de um GMS.

\section{1.}

\section{Características e diferenciais do modelo conceitual}

O modelo compreende cinco etapas, a saber: (i) definição dos stakeholders do grupo multissetorial; (ii) construção da matriz de materialidade para seleção de aspectos por categoria da sustentabilidade, com uso do método AHP; (iii) definição da estrutura hierárquica para seleção dos indicadores de desempenho, integrandose a estrutura GRI à ferramenta de gerenciamento estratégico Balanced Scorecard (BSC); (iv) hierarquização e seleção de indicadores de desempenho por categoria da sustentabilidade, com uso do método AHP-TOPSIS; e (v) elaboração das identidades dos indicadores selecionados e respectivas métricas.

Os resultados desta modelagem poderão ser replicados em processos de avaliação de desempenho em sustentabilidade de outros grupos multissetoriais no Brasil e no exterior. No âmbito da GRI, poderão contribuir para a elaboração de um suplemento orientativo para grupos multissetoriais, i.e., G4 Multisectoral Disclosures.

Dentre os diferenciais do modelo, destacam-se: (i) o uso de critérios e ferramentas da teoria dos stakeholders para a construção da matriz de materialidade de grupos multissetoriais; (ii) integração da estrutura de indicadores GRI à ferramenta Balanced Scorecard (BSC) para o gerenciamento estratégico da sustentabilidade pelo GMS; (iii) emprego de um método híbrido multicritério para seleção dos aspectos da sustentabilidade por categoria (econômica, ambiental e social) e para hierarquização dos respectivos indicadores e métricas, também por 
categoria. Nos itens a seguir, discutem-se esses diferenciais, considerados como pressupostos básicos para a modelagem propriamente dita.

\subsection{1.}

Uso de critérios e ferramentas da teoria dos stakeholders para a construção da matriz de materialidade de grupos multissetoriais

A definição dos stakeholders do GMS privilegia a representatividade daqueles que possuem interesse na sustentabilidade do grupo como um todo.

Para definir os principais stakeholders que deverão participar da construção da matriz de materialidade do GMS (etapa 2 deste modelo), propõe-se uma abordagem metodológica baseada nos trabalhos seminais de Mitchell et al. (1997) e Freeman (1984) e, mais recentemente, na versão atualizada por Freeman et al. (2007). Esta abordagem encontra-se descrita no item 4.3.2.

O principal diferencial desta abordagem refere-se ao desdobramento do processo de definição dos stakeholders externos em três subprocessos, focalizandose respectivamente as categorias econômica, ambiental e social da sustentabilidade. Acredita-se que essa divisão poderá aumentar a qualidade das percepções associadas aos focos de decisão (aspectos materiais constantes das Diretrizes G4 da GRI em cada categoria). Outro diferencial é a aplicação inicial de uma taxonomia, que permite classificar os stakeholders externos em primários e secundários. $\mathrm{Na}$ sequência, adotam-se os critérios propostos por Mitchell et al. (1997) para refinar a escolha dos stakeholders por categoria/subcategoria da sustentabilidade.

\subsection{2.} Integração da estrutura de indicadores GRI à ferramenta Balanced
Scorecard (BSC) para gerenciamento estratégico da sustentabilidade

A proposta de integração da estrutura de indicadores GRI à ferramenta do BSC para gerenciamento estratégico da sustentabilidade corporativa de grupos multissetoriais visa um aproveitamento mais sinérgico de todos os esforços relacionados à avaliação de desempenho em sustentabilidade do grupo.

As Diretrizes GRI incluem uma estrutura composta por três categorias, 46 aspectos materiais e 91 indicadores, distribuídos dentre esses aspectos, conforme quadro 4.1.

Como abordado no item 2.2.1., a ferramenta Balanced Scorecard ou BSC é voltada para o gerenciamento estratégico e de avaliação do desempenho global, permitindo criar uma visão compartilhada dos objetivos de longo prazo a serem atingidos em todos os níveis da organização. Comparando-se com os sistemas de 
medição convencionais, baseados exclusivamente na vertente financeira, o BSC é capaz de direcionar a organização para a sua visão de futuro, definindo quais os objetivos a atingir e medindo seus resultados a partir de quatro perspectivas distintas (Kaplan e Norton, 1992; 1997; 2000; 2003).

Por meio de processo participativo, constrói-se um mapa estratégico, no qual destacam-se aqueles objetivos e indicadores que são críticos para a geração de valor. Por essa razão, assim como o Relatório de Sustentabilidade segundo as Diretrizes G\$ da GRI, o BSC tem sido considerado um poderoso mecanismo de comunicação institucional e harmonização de interesses distintos.

O BSC contempla quatro perspectivas para mensuração do desempenho global da organização: (i) financeira; (ii) mercado/visão externa; (iii) processos internos; e (iv) crescimento e aprendizagem.

Inicialmente, a integração da estrutura hierárquica GRI às quatro perspectivas da ferramenta BSC se dá pela associação dos indicadores de cada categoria da sustentabilidade com as quatro perspectivas do BSC (quadro 4.1). Este quadro foi elaborado com base na classificação proposta por Costa e Menichini (2013) e consulta a especialistas da área de monitoramento e avaliação de desempenho em sustentabilidade.

Como consequência, os indicadores GRI - associados ao Mapa Estratégico do GMS no nível corporativo multissetorial e aos Mapas Estratégicos das empresas que integram o GMS - poderão fazer parte de uma sistemática de gerenciamento estratégico do GMS e de suas empresas, ao mesmo tempo que integram os respectivos Relatórios de Sustentabilidade do Grupo e de suas empresas para comunicação com seus stakeholders.

Na sequência, busca-se identificar quais objetivos de longo prazo expressos no Mapa Estratégico do GMS poderão ser monitorados por indicadores GRI, conhecendo-se seu vínculo com as perspectivas BSC, conforme quadro 4.1, a seguir. Deve-se ressaltar que poderão ser identificados objetivos de longo prazo expressos no Mapa Estratégico do GMS sem vínculos com aspectos materiais das Diretrizes G4 da GRI. Nesses casos, na construção dos Mapas Estratégicos com uso da ferramenta BSC, haverá necessidade de complementação com outros indicadores-chave (key performance indicators ou KPIs), além daqueles cobertos pela estrutura de indicadores propostos nas Diretrizes G4 da GRI. 
Quadro 4.1 - Classificação dos indicadores GRI segundo as perspectivas da ferramenta BSC

\begin{tabular}{|c|c|c|c|c|c|}
\hline \multirow{2}{*}{$\begin{array}{l}\text { Categoria/ } \\
\text { Subcategoria }\end{array}$} & \multirow[t]{2}{*}{ Aspectos materiais } & \multicolumn{4}{|c|}{ Indicadores GRI classificados segundo as perspectivas BSC } \\
\hline & & Financeira & Clientes/Visão externa & \multirow[t]{2}{*}{ Processos } & \multirow{2}{*}{$\begin{array}{l}\text { Crescimento e } \\
\text { aprendizagem } \\
E C 3\end{array}$} \\
\hline \multirow[t]{4}{*}{ Econômica (EC) } & Desempenho econômico & $\begin{array}{ll}\text { EC1 } & \text { EC2 } \\
\text { EC4 } & \end{array}$ & & & \\
\hline & Presença no mercado & & EC6 & & EC5 \\
\hline & Impactos econômicos indiretos & & EC7 $E C 8$ & & \\
\hline & Práticas de compra & EC9 & & & \\
\hline \multirow[t]{12}{*}{ Ambiental (EN) } & Materiais & & & EN1+EN2 & \\
\hline & Energia & & EN7 & EN3 3 EN4 EN5 EN6 & \\
\hline & Água & & & EN8+EN9 EN10 & \\
\hline & Biodiversidade & & EN11+EN12 EN13 EN14 & & \\
\hline & Emissões & & EN15 & $\begin{array}{l}\text { EN16+EN17 EN19+EN20 EN21 } \\
\text { EN18 }\end{array}$ & \\
\hline & Efluentes e resíduos & & EN22+EN24 EN25 & EN23 & EN26 \\
\hline & Produtos e serviços & EN28 & EN27 & & \\
\hline & Conformidade & & EN29 & & \\
\hline & Transportes & EN30 & & & \\
\hline & Geral & EN31 & & & \\
\hline & Avaliação ambiental de fornecedores & & EN33 & EN32 & \\
\hline & Mecanismos de queixas e reclamações relacionadas a impactos ambientais & & EN34 & & \\
\hline \multirow{8}{*}{$\begin{array}{l}\text { Social/Práticas } \\
\text { trabalhistas e trabalho } \\
\text { decente (LA) }\end{array}$} & Emprego & & & & LA1+LA2 LA3 \\
\hline & Relações entre trabalhadores e empregadores & & & & LA4 \\
\hline & Saúde e segurança no trabalho & & & LA7 & LA5 LA6 LA8 \\
\hline & Treinamento e educação & & & & LA9 LA10 LA11 \\
\hline & Diversidade e igualdade de oportunidades & & & & LA12 \\
\hline & Igualdade de remuneração entre homens e mulheres & & & & LA13 \\
\hline & Avaliação de fornecedores em práticas trabalhistas & & & LA15 & LA14 \\
\hline & Mecanismos de queixas e reclamações relacionadas a práticas trabalhistas & & LA16 & & \\
\hline \multirow{10}{*}{$\begin{array}{l}\text { Social/Direitos humanos } \\
\text { (HR) }\end{array}$} & Investimentos & & $\mathrm{HR} 1+\mathrm{HR} 2$ & & \\
\hline & Não discriminação & & & & HR3 \\
\hline & Liberdade de associação e negociação coletiva & & & & HR4 \\
\hline & Trabalho infantil & & HR5 & & \\
\hline & Trabalho forçado ou análogo ao escravo & & HR6 & & \\
\hline & Práticas de segurança & & & & HR7 \\
\hline & Direitos indígenas & & HR8 & & \\
\hline & Avaliação & & HR9 & & \\
\hline & Avaliação de fornecedores em direitos humanos & & & HR10 & HR11 \\
\hline & Mecanismos de queixas e reclamações relacionadas a direitos humanos & & HR12 & & \\
\hline \multirow[t]{7}{*}{ Social/Sociedade (SO) } & Comunidades locais & & SO1 & & $\mathrm{SO} 2$ \\
\hline & Combate à corrupção & & SO5 & $\mathrm{SO} 3$ & SO4 \\
\hline & Políticas públicas & SO6 & & & \\
\hline & Concorrência desleal & & SO7 & & \\
\hline & Conformidade & SO8 & & & \\
\hline & Avaliação de fornecedores em impactos na sociedade & & & SO10 & SO9 \\
\hline & $\begin{array}{l}\text { Mecanismos de queixas e reclamações relacionadas a impactos na } \\
\text { sociedade }\end{array}$ & & SO11 & & \\
\hline \multirow{5}{*}{$\begin{array}{l}\text { Social/Responsabilidade } \\
\text { pelo produto (PR) }\end{array}$} & Saúde e segurança do cliente & & & PR1 & \\
\hline & Rotulagem de produtos e serviços & & PR3 & PR4 & \\
\hline & Comunicação de marketing & & PR6 & PR7 & \\
\hline & Privacidade do cliente & & PR8 & & \\
\hline & Conformidade & PR9 & & & \\
\hline
\end{tabular}

Fonte: Elaboração própria, com base em Costa e Menichini (2013). A classificação dos indicadores GRI refere-se ao alinhamento preponderante do indicador a uma das perspectivas da ferramenta BSC. 


\subsection{3.}

\section{Integração de métodos multicritério de apoio à decisão ao modelo}

A utilização do método AHP (Analytic Hierarchy Process) se dá em duas etapas do modelo, a saber: (i) na etapa 2, para avaliar a significância de cada aspecto material sobre os demais aspectos materiais de uma dada categoria (econômica, ambiental ou social), segundo as percepções dos stakeholders externos e dos gestores do GMS; e (ii) na etapa 4, para definir os pesos dos critérios para seleção dos indicadores GRI 'candidatos', por categoria/subcategoria.

Na etapa 2, constroem-se duas matrizes de comparação pareada referentes às categorias econômica e ambiental e quatro matrizes relativas às subcategorias da categoria social, a saber: (i) práticas trabalhistas e trabalho decente; (ii) direitos humanos; (iii) sociedade; e (iv) responsabilidade pelo produto. Como resultados, obtém-se os julgamentos dos gestores do GMS sobre a significância dos impactos dos aspectos materiais de cada categoria/subcategoria sobre os negócios do Grupo (eixo ' $x$ ' da matriz de materialidade).

Da mesma forma, conduz-se esse mesmo procedimento para se obter os julgamentos dos stakeholders externos sobre a influência dos aspectos materiais sobre suas avaliações e decisões.

Já na etapa 4, a aplicação do método AHP compreende duas etapas: (i) organização da estrutura hierárquica, ou seja, definição do objetivo da decisão, estabelecimento dos critérios e identificação das alternativas, refletindo as relações hierárquicas existentes entre esses elementos; e (ii) coleta de julgamentos de valor sobre a importância de um critério sobre os demais, mediante comparação pareada dos critérios, que neste caso são as perspectivas do BSC.

Ainda na etapa 4, utiliza-se o método TOPSIS (Technique for Order Preference by Similarity to Ideal Solution) para a etapa de seleção dos indicadores 'candidatos' em cada categoria/subcategoria. O método híbrido AHP-TOPSIS foi escolhido nesta modelagem por permitir a avaliação do desempenho de alternativas, por meio da sua similaridade com uma solução considerada ideal. A melhor solução ou alternativa é aquela que se encontra mais distante da solução não ideal, ou de maneira equivalente, mais próxima da solução ideal. 


\subsection{4. \\ Definição de metas de sustentabilidade de curto, médio e longo prazo, alinhadas à visão de futuro do grupo multissetorial}

A modelagem aqui proposta para grupos multissetoriais busca tornar os respectivos relatórios de sustentabilidade instrumentos de gerenciamento estratégico da sustentabilidade corporativa pela integração GRI-BSC.

Os indicadores GRI de sustentabilidade corporativa, quando integrados ao sistema de gerenciamento estratégico do GMS (pela sua vinculação com os objetivos de longo prazo expressos no Mapa Estratégico $B S C$ do Grupo), permitirão manter e atualizar séries históricas desses indicadores e, consequentemente, auxiliar as análises de tendências e apoiar processos decisórios corporativos.

Tais análises permitirão definir ou revisar metas de sustentabilidade de curto, médio e longo prazo. Portanto, os compromissos assumidos pelo GMS passam a ser sustentados pela mensuração e avaliação sistemática dos indicadores GRI, vinculados aos objetivos e iniciativas estratégicas do Grupo.

\section{2. \\ Visão geral do modelo conceitual}

Com base nos referenciais teóricos e normativos abordados respectivamente nos capítulos 2 e 3, propõe-se um modelo conceitual para o monitoramento e avaliação do desempenho em sustentabilidade de grupos multissetoriais, a ser aplicado no nível corporativo desses grupos.

A figura 4.1, a seguir, fornece graficamente a visão geral do modelo proposto em cinco etapas, a saber: (i) definição dos stakeholders externos e internos do grupo multissetorial; (ii) construção da matriz de materialidade com uso do método AHP para seleção de aspectos materiais; (iii) definição da estrutura hierárquica para seleção dos indicadores GRI, integrada à ferramenta BSC; (iv) hierarquização e seleção dos indicadores GRI com uso do método AHP-TOPSIS; e (v) elaboração das identidades dos indicadores selecionados e respectivas métricas. 


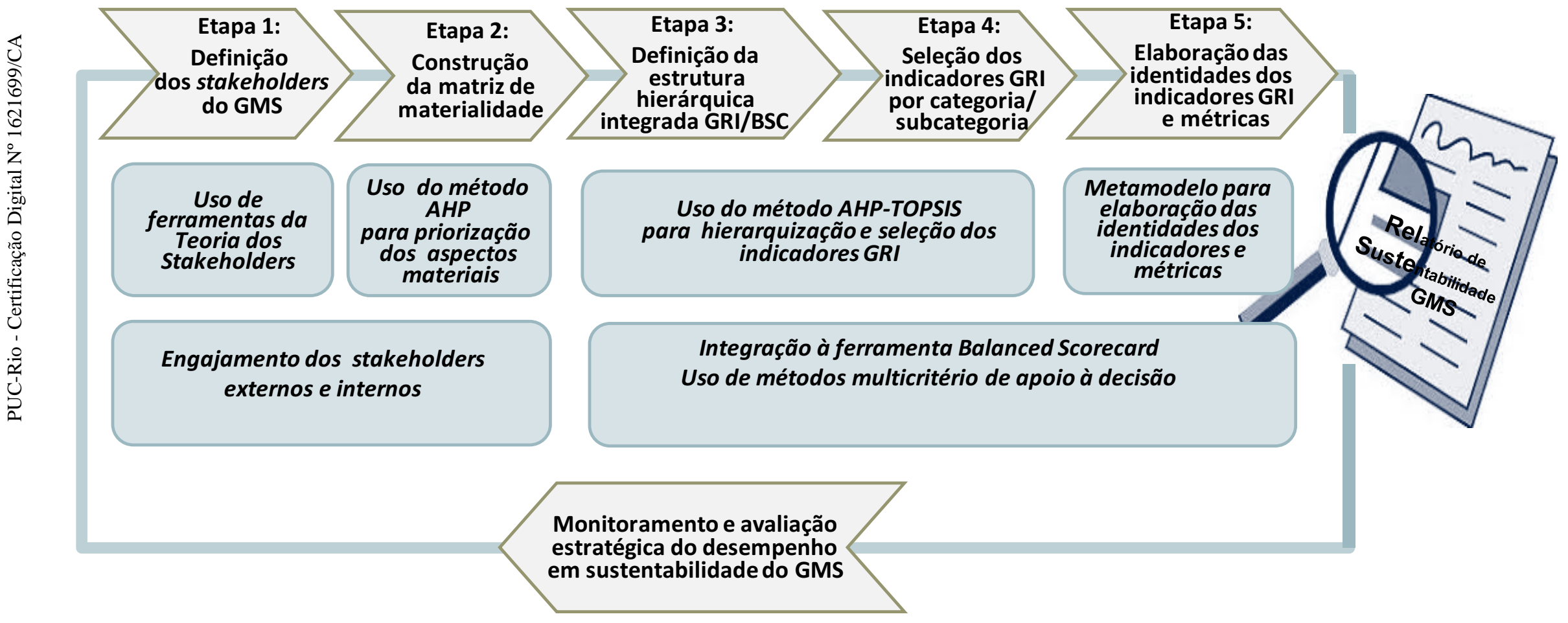

Figura 4.1 - Visão geral do modelo para monitoramento e avaliação de desempenho em sustentabilidade de grupos multissetoriais Fonte: Elaboração própria. 
Busca-se na figura 4.1 destacar os elementos metodológicos que conferiram diferenciais ao modelo proposto, como: (i) uso de ferramentas consagradas da teoria dos stakeholders na etapa 1, visando seu efetivo engajamento e resposta; (ii) emprego do método AHP para avaliação e priorização dos aspectos materiais; (iii) integração das perspectivas BSC à estrutura hierárquica para seleção dos indicadores GRI em cada categoria/subcategoria da sustentabilidade; (iv) uso do método híbrido multicritério AHP-TOPSIS na etapa 4; e (v) proposta de um metamodelo para elaborar as identidades dos indicadores GRI selecionados, visando sua integração à sistemática de monitoramento e avaliação estratégica do desempenho em sustentabilidade do GMS.

\section{3.}

\section{Visão detalhada de aplicação do modelo}

Descrevem-se nesta seção as etapas que integram o modelo em foco, aplicado no nível corporativo multissetorial.

\subsection{1.}

\section{Etapa 1: Definição dos stakeholders do grupo multissetorial}

Considerando-se a ênfase das Diretrizes G4 da GRI à materialidade para o fornecimento de informações que reflitam os impactos econômicos, ambientais e sociais das atividades das organizações, propõe-se que o grupo multissetorial adote o conceito mais abrangente de stakeholders, classificando-os em primários e secundários, como abordado no capítulo 2.

Considera-se como stakeholders primários os clientes; investidores; fornecedores e representantes das comunidades do entorno. Como stakeholders secundários, situam-se órgãos governamentais, universidades/instituições de Ciência e Tecnologia (ICT), mídias e outros grupos especiais que a organização entenda haver representatividade significativa.

Como mencionado no capítulo 2, a partir desta primeira classificação (stakeholders primários e secundários), os gestores do grupo multissetorial deverão selecionar aqueles stakeholders externos de cada grupo, que deverão ser convidados a participar do processo de construção das matrizes de materialidade. Para tal, adotam-se os critérios propostos por Mitchell et al. (1997) e uma escala de três níveis. Esses critérios são: (i) poder; (ii) legitimidade; e (iii) urgência. Aos níveis 
da escala, atribui-se a seguinte pontuação para cada representante dos grupos de stakeholders, a saber: baixo (a) - 1 ponto; médio (a) - 3 pontos; e alto (a) - 5 pontos.

O quadro 4.2 apresenta uma proposta de formulário a ser preenchido pelos gestores do GMS, com o objetivo de selecionar os principais stakeholders externos em cada grupo. Os representantes selecionados deverão ser convidados para participar da construção da matriz de materialidade, com uso do método AHP (etapa 2 do modelo).

A seleção dos stakeholders externos deverá se basear na pontuação alcançada pelos representantes de cada grupo de stakeholders, priorizando-se os de maior pontuação.

Cabe ressaltar que o formulário apresentado no quadro 4.2 constitui material de apoio para a seleção dos stakeholders externos.

Quanto aos stakeholders internos, recomenda-se incluir neste processo os gestores de primeira linha do Grupo, os responsáveis pela elaboração do Relatório de Sustentabilidade e pelo Sistema de Gerenciamento Estratégico do Grupo; gestores dos negócios setoriais do GMS (pelo menos um representante de cada setor de atuação do GMS); e pelo menos um membro do Conselho de Administração do Grupo. 
Quadro 4.2 - Formulário para definição dos stakeholders externos do grupo multissetorial no contexto corporativo

\begin{tabular}{|c|c|c|c|c|c|c|c|c|c|c|c|c|}
\hline & \multirow{3}{*}{$\begin{array}{c}\text { Grupo de } \\
\text { stakeholders }\end{array}$} & \multirow{3}{*}{ Principais stakeholders } & \multicolumn{9}{|c|}{ Critérios para seleção dos stakeholders externos } & \multirow{3}{*}{$\begin{array}{c}\text { Total } \\
\text { (Soma } \\
\text { ponderada) }\end{array}$} \\
\hline & & & \multicolumn{3}{|l|}{ Poder* } & \multicolumn{3}{|c|}{ Legitimidade $^{\star *}$} & \multicolumn{3}{|c|}{ Urgência $^{\star * *}$} & \\
\hline & & & $\begin{array}{l}\text { Baixo } \\
{[1]}\end{array}$ & \begin{tabular}{|l|} 
Médio \\
[3]
\end{tabular} & \begin{tabular}{|l|} 
Alto \\
{$[5]$}
\end{tabular} & $\begin{array}{c}\text { Baixa } \\
{[1]}\end{array}$ & \begin{tabular}{|c|} 
Média \\
[3]
\end{tabular} & \begin{tabular}{|ll} 
Alta & \\
&
\end{tabular} & $\begin{array}{c}\text { Baixa } \\
{[1]}\end{array}$ & $\begin{array}{r}\text { Média } \\
{[3]}\end{array}$ & ${ }_{[5]}^{\text {Alta }_{[5}}$ & \\
\hline \multirow{12}{*}{ 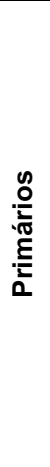 } & \multirow{3}{*}{ Clientes } & Cliente $_{1}$ & & & & & & & & & & \\
\hline & & Cliente $_{2}$ & & & & & & & & & & \\
\hline & & Cliente $_{n}$ & & & & & & & & & & \\
\hline & \multirow{3}{*}{ Investidores } & Investidor $_{1}$ & & & & & & & & & & \\
\hline & & Investidor $_{2}$ & & & & & & & & & & \\
\hline & & Investidor $_{\mathrm{n}}$ & & & & & & & & & & \\
\hline & \multirow{3}{*}{ Fornecedores } & Fornecedor $_{1}$ & & & & & & & & & & \\
\hline & & Fornecedor $_{2}$ & & & & & & & & & & \\
\hline & & Fornecedor $_{n}$ & & & & & & & & & & \\
\hline & \multirow{3}{*}{ Comunidades } & Representante de comunidade $_{1}$ & & & & & & & & & & \\
\hline & & Representante de comunidade ${ }_{2}$ & & & & & & & & & & \\
\hline & & Representante de comunidade $_{n}$ & & & & & & & & & & \\
\hline \multirow{10}{*}{ 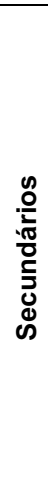 } & \multirow{3}{*}{ Órgãos de governo } & Representante do órgão ${ }_{1}$ & & & & & & & & & & \\
\hline & & Representante do órgão ${ }_{2}$ & & & & & & & & & & \\
\hline & & Representante do órgãon & & & & & & & & & & \\
\hline & \multirow{3}{*}{\begin{tabular}{|l|} 
Universidades e \\
Instituições de \\
Ciência \&Tecnologia \\
parceiras \\
\end{tabular}} & Representante da ICT & & & & & & & & & & \\
\hline & & Representante da $\mathrm{ICT}_{2}$ & & & & & & & & & & \\
\hline & & Representante da ICT $\mathrm{n}$ & & & & & & & & & & \\
\hline & \multirow{3}{*}{ Mídias } & Representante da mídia ${ }_{1}$ & & & & & & & & & & \\
\hline & & Representante da mídia 2 & & & & & & & & & & \\
\hline & & Representante da mídia $a_{n}$ & & & & & & & & & & \\
\hline & $\begin{array}{l}\text { Grupos especiais } \\
\text { (citar quais grupos) }\end{array}$ & $\begin{array}{l}\text { Citar principais representantes } \\
\text { de grupos especiais e avaliá-los } \\
\text { segundo os critérios poder, } \\
\text { legitimidade e urgência }\end{array}$ & & & & & & & & & & \\
\hline
\end{tabular}

Notas: $\left(^{*}\right)$ - relacionado à obrigação da organização fazer algo que não seria feito sem ser solicitado pelo stakeholder externo; $\left({ }^{* \star}\right)$ - relacionada com a percepção pela organização de que as ações empreendidas pelo stakeholder são desejáveis, apropriadas a um sistema social de normas, valores e crenças; $\left({ }^{\star * *}\right)$ - relacionada com a necessidade da velocidade de resposta da organização em relação à demanda do stakeholder.

Fonte: Elaboração própria. 


\subsection{2.}

Etapa 2: Construção da matriz de materialidade com uso do método AHP: seleção de aspectos materiais por categoria da sustentabilidade

Nesta etapa, deverão ser construídas seis matrizes de materialidade do GMS, sendo uma para a categoria econômica, uma para a categoria ambiental e quatro para as respectivas subcategorias sociais. A construção dessas matrizes visa apoiar a priorização daqueles aspectos materiais que deverão ser considerados no Relatório de Sustentabilidade do GMS.

Conforme as Diretrizes G4 da GRI, as matrizes de materialidade são compostas por dois eixos: (i) significância dos impactos de cada aspecto material para o GMS (visão interna); e (ii) influência de cada aspecto material sobre as avaliações e decisões dos stakeholders (visão externa).

O método AHP, descrito no apêndice 1, foi o método de escolha para definir o grau de importância dos aspectos materiais de cada categoria/subcategoria, segundo as visões dos stakeholders internos e externos. A partir dos resultados da aplicação do método AHP, os aspectos materiais de cada categoria/subcategoria deverão ser plotados nas respectivas matrizes de materialidade, adotando-se os parâmetros apresentados adiante na tabela 4.5.

A escolha do método AHP deveu-se aos seguintes fatores:

- Modelagem em hierarquias e as comparações pareadas facilitam o entendimento geral do problema;

- Aplicável a julgamentos subjetivos, que é o caso dos questionamentos a serem gerados para a seleção dos aspectos materiais que deverão compor matrizes de materialidade;

- Processo que pode ser documentado e repetido, caso haja necessidade de uma eventual inclusão de novos aspectos, por exemplo, por ocasião de uma eventual revisão dos aspectos materiais pela GRI;

- O uso do método é apropriado para grupos de decisão, como é o caso da aplicação futura pelo Grupo Algar e por outros grupos multissetoriais.

As comparações pareadas dos aspectos materiais de cada categoria/subcategoria da sustentabilidade deverão ocorrer em dois momentos. No primeiro momento, os julgamentos deverão ser realizados segundo a visão dos stakeholders internos, ou seja, avaliando-se a significância dos impactos dos aspectos materiais nos negócios do GMS. Em um segundo momento, os julgamentos deverão ser conduzidos pelos representantes dos principais 
stakeholders externos em relação à influência dos aspectos materiais de cada categoria/subcategoria sobre suas avaliações e decisões.

Os valores da diagonal de cada matriz deverão ser sempre 1 , pois refletem a comparação de um aspecto material com ele mesmo. A leitura deve ser realizada a partir do aspecto indicado na linha em relação ao indicado na coluna. Por fim, o recíproco de cada elemento da matriz recebe o valor inverso da avaliação. Por exemplo, se A3 em relação a A4 é muito forte, recebendo pontuação 7, então A4 em relação a A3 receberá o valor inverso, 1/7.

Com as matrizes das categorias/subcategorias já preenchidas com os julgamentos, sugere-se a utilização do Sistema Computacional IPÊ, versão $1.0^{3}$, para o cálculo do grau de importância dos aspectos materiais, visando à seleção daqueles que deverão compor as respectivas matrizes de materialidade (por categoria/subcategoria da sustentabilidade).

A título de ilustração, as tabelas 4.1 e 4.2 mostram um exemplo didático das matrizes referentes à categoria 'Econômica', construídas com os aspectos materiais desta categoria estabelecidos nas Diretrizes G4 da GRI.

Tabela 4.1- Exemplo didático da comparação pareada dos aspectos materiais da categoria 'Econômica': visão dos stakeholders internos

\begin{tabular}{l|c|c|c|c}
\hline Aspectos materiais & AM1 & AM2 & AM3 & AM4 \\
\hline AM1: Desempenho econômico & $\mathbf{1}$ & 2 & 4 & 3 \\
\hline AM2: Presença no mercado & $1 / 2$ & $\mathbf{1}$ & 3 & 2 \\
\hline AM3: Impactos econômicos indiretos & $1 / 4$ & $1 / 3$ & $\mathbf{1}$ & $1 / 2$ \\
\hline AM4: Práticas de compra & $1 / 3$ & $1 / 2$ & 2 & $\mathbf{1}$ \\
\hline
\end{tabular}

Fonte: Elaboração própria.

Tabela 4.2 - Comparação pareada aspectos materiais da categoria 'Econômica': visão dos stakeholders externos

\begin{tabular}{l|l|l|l|l}
\hline Aspectos materiais & AM1 & AM2 & AM3 & AM4 \\
\hline AM1: Desempenho econômico & $\mathbf{1}$ & 2 & 3 & 3 \\
\hline AM2: Presença no mercado & $1 / 2$ & $\mathbf{1}$ & 2 & 4 \\
\hline AM3: Impactos econômicos indiretos & $1 / 3$ & $1 / 2$ & $\mathbf{1}$ & 2 \\
\hline AM4: Práticas de compra & $1 / 3$ & $1 / 4$ & $1 / 2$ & $\mathbf{1}$ \\
\hline
\end{tabular}

Fonte: Elaboração própria.

\footnotetext{
${ }^{3}$ O sistema computacional IPÊ versão 1.0 é um sistema que possibilita o desenvolvimento e implementação de modelos de auxilio multicritério à decisão, fundamentados no Método de Análise Hierárquica (AHP) (Costa, 2004). Esse sistema foi desenvolvido pela Universidade Federal Fluminense (UFF), com o propósito de disseminar o uso do algoritmo do AHP proposto por Thomas L. Saaty (Costa, 2004).
} 
As tabelas 4.3 e 4.4 mostram as classificações dos aspectos materiais, obtidas segundo as visões dos stakeholders internos e externos, e as respectivas 'Razões de Consistência' (RC) dos julgamentos realizados em ambas as situações deste exemplo didático.

Tabela 4.3 - Hierarquização dos aspectos materiais da categoria 'Econômica', segundo a visão dos stakeholders internos

\begin{tabular}{|c|c|c|c|}
\hline Aspecto material da categoria 'Econômica' & $\begin{array}{l}\text { Grau de } \\
\text { importância }\end{array}$ & Ranking & $\mathbf{R C}$ \\
\hline AM1: Desempenho econômico & 0,466 & 10 & \multirow{4}{*}{$\begin{array}{l}0,011 \\
\text { Valor dentro do padrão } \\
R C \leq=0,1\end{array}$} \\
\hline AM2: Presença no mercado & 0,277 & 20 & \\
\hline AM3: Impactos econômicos indiretos & 0,096 & 40 & \\
\hline AM4: Práticas de compra & 0,161 & 30 & \\
\hline
\end{tabular}

Fonte: Elaboração própria.

Tabela 4.4 - Hierarquização dos aspectos materiais da categoria 'Econômica', segundo a visão dos stakeholders externos

\begin{tabular}{|c|c|c|c|}
\hline Aspecto material da categoria 'Econômica' & $\begin{array}{l}\text { Grau de } \\
\text { importância }\end{array}$ & Ranking & RC \\
\hline AM1: Desempenho econômico & 0,439 & 10 & \multirow{4}{*}{$\begin{array}{l}0,036 \\
\text { Valor dentro do padrão } \\
\qquad R C \leq=0,1\end{array}$} \\
\hline AM2: Presença no mercado & 0,301 & 20 & \\
\hline AM3: Impactos econômicos indiretos & 0,160 & 3은 & \\
\hline AM4: Práticas de compra & 0,099 & 4 은 & \\
\hline
\end{tabular}

Fonte: Elaboração própria.

De acordo com a descrição do método AHP (apêndice 1), os valores para a "Razão de Consistência" (RC) devem ser sempre menores que 0,1. Os valores RC mostrados nas tabelas 4.3 e 4.4 estão de acordo com o esperado, com valores menores a 0,1 , indicando que as comparações entre os aspectos materiais nos dois casos foram adequadas.

Este procedimento com emprego do método AHP deverá ser adotado para as categorias 'Econômica' e 'Ambiental' e para as subcategorias da categoria 'Social', a saber: 'Práticas trabalhistas e trabalho decente'; 'Direitos humanos'; 'Sociedade' e 'Responsabilidade sobre o produto'.

Propõe-se que a construção das matrizes de materialidade por categoria/subcategoria (seis no total) leve em consideração a escolha dos stakeholders mais relevantes para cada categoria/subcategoria, ou seja, econômica, ambiental e subcategorias sociais. Nesse sentido, representantes de órgãos ambientais deverão ser convidados para a construção da matriz de materialidade da categoria ambiental, mas não necessariamente para a construção das demais matrizes (econômica e subcategorias sociais). Nesses últimos casos, deverão ser 
convidados outros atores de reconhecida relevância para a discussão dos aspectos abordados nas respectivas categorias/subcategorias.

Para a plotagem dos aspectos materiais de cada categoria/subcategoria nas respectivas matrizes de materialidade, deverão ser adotadas escalas de importância conforme rankings obtidos pela aplicação do método AHP para hierarquização dos aspectos materiais, como mostrado no exemplo das tabelas 4.3 e 4.4. Assim, consideram-se os aspectos materiais posicionados nos primeiros lugares, como sendo os de significância ou influência alta. Já os aspectos que ficaram nas posições intermediárias são considerados de significância ou influência média. Finalmente, os aspectos materiais situados em posições inferiores são classificados como sendo de significância ou influência baixa.

$\mathrm{Na}$ tabela 4.5 , propõem-se os parâmetros para posicionamento dos aspectos materiais nas respectivas matrizes de materialidade.

Tabela 4.5 - Parâmetros para posicionamento dos aspectos materiais nas respectivas matrizes de materialidade

\begin{tabular}{|c|c|c|c|c|}
\hline \multirow[t]{2}{*}{ Categoria/subcategoria } & \multirow{2}{*}{$\begin{array}{l}\text { Aspectos } \\
\text { materiais } \\
(\mathrm{n} \div)\end{array}$} & \multicolumn{3}{|c|}{ Nível de significância ou influência } \\
\hline & & Alta & Média & Baixa \\
\hline Econômica & 4 & 10 lugar & $2 \div$ e 30 lugares & 4ㅇ lugar \\
\hline Ambiental & 12 & 10 ao 3ㅇ lugares & 40 ao 9o lugares & 10 ao $12 \%$ lugares \\
\hline $\begin{array}{l}\text { Social/Práticas trabalhistas } \\
\text { e trabalho decente }\end{array}$ & 8 & 1ㅇ e 2ㅇ lugares & 30 ao 6o lugares & 70 e 8ㅇ lugares \\
\hline Social/Direitos humanos & 10 & 10 e 20 lugares & 3ㅇ ao 8ㅇ lugares & 9 e 10 lugares \\
\hline Social/Sociedade & 7 & 10 lugar & 20 ao 60 lugares & 70 lugar \\
\hline $\begin{array}{l}\text { Social/Responsabilidade } \\
\text { pelo produto }\end{array}$ & 5 & 10 lugar & 20 ao 4ㅇ lugares & 5o lugar \\
\hline Total & 46 & 10 & 26 & 10 \\
\hline
\end{tabular}

Após a plotagem dos aspectos materiais de cada categoria/subcategoria nas respectivas matrizes de materialidade, os gestores do GMS deverão construir a matriz de materialidade corporativa, plotando todos os 46 aspectos, segundo seus posicionamentos nos rankings gerados pelos julgamentos dos stakeholders externos (eixo y) e dos stakeholders internos (eixo x). A título de ilustração, a figura 4.2 mostra um exemplo didático representativo de uma matriz de materialidade de um GMS fictício, com destaque para os aspectos materiais da categoria 'econômica'.

$\mathrm{O}$ aspecto material posicionado no nonante superior direito refere-se ao 'Desempenho econômico'. Este aspecto deverá ser priorizado para fins da elaboração do Relatório de Sustentabilidade do Grupo. Caso outros aspectos materiais da categoria 'econômica' estivessem nos nonantes 'alta significânciamédia influência' e 'média significância-alta influência' poderiam ser considerados 
pelo Gripo para inclusão em seu Relatório de Sustentabilidade. Neste exemplo didático representado na figura 4.2, nenhum aspecto situou-se nos referidos nonantes. Portanto, somente o aspecto 'Desempenho econômico' deverá ser considerado prioritário neste caso, para fins da elaboração do relatório de sustentabilidade do Grupo.

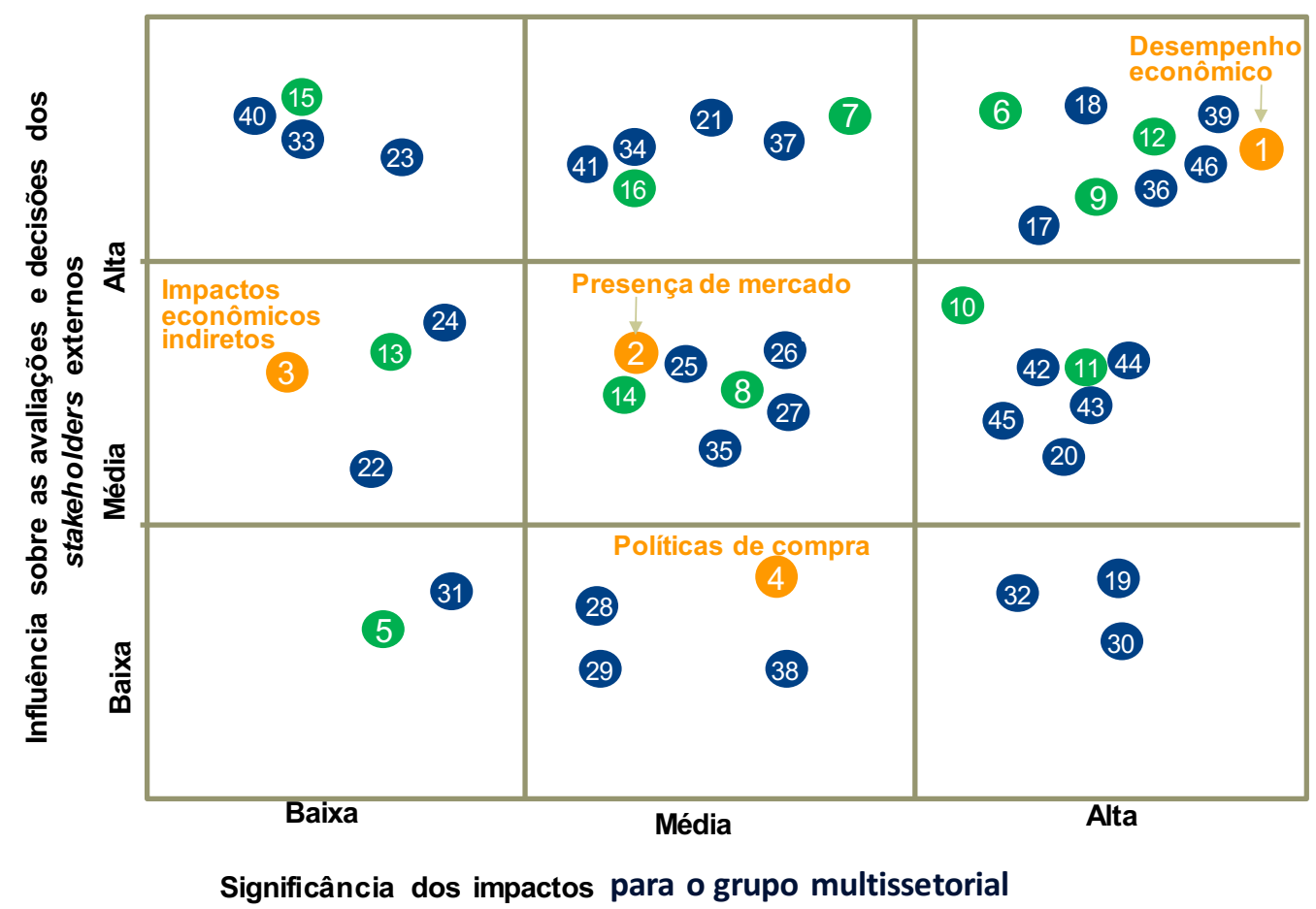

Legenda: cor amarela - aspectos materiais da categoria 'Econômica'; cor azul - aspectos materiais da categoria 'Social'; e cor verde - aspectos materiais da categoria 'Ambiental'.

Figura 4.2 - Exemplo didático de uma matriz de materialidade de um GMS, no contexto corporativo, com destaque para a categoria 'econômica' (exemplo didático)

Fonte: Elaboração própria, com base em GRI (2015).

Portanto, neste exemplo didático, deverão ser priorizados pelo GMS os aspectos materiais 1, 6, 9, 12, 17, 18, 36, 39 e 46. Em um segundo patamar de prioridade, o GMS deve considerar os aspectos materiais situados nos nonantes 'alta significância-média influência' e 'média significância-alta influência' da figura 4.2.

\subsection{3.}

Etapa 3: Definição da estrutura hierárquica para hierarquização e seleção dos indicadores GRI à luz das perspectivas da ferramenta Balanced Scorecard

O modelo proposto contribuirá para o gerenciamento estratégico efetivo e sistêmico do desempenho em sustentabilidade por grupos multissetoriais, pelo 
alinhamento dos indicadores GRI 'candidatos' ${ }^{4}$ referentes aos aspectos materiais priorizados na etapa 2 , também chamados de indicadores 'candidatos', com as perspectivas da ferramenta Balanced Scorecard (BSC).

O quadro 4.1, apresentado anteriormente no item 4.1.2, fornece as chaves para este alinhamento.

A figura 4.3, a seguir, representa a estrutura hierárquica que deverá ser adotada pelo GMS para a etapa seguinte de seleção propriamente dita dos indicadores GRI 'candidatos'.

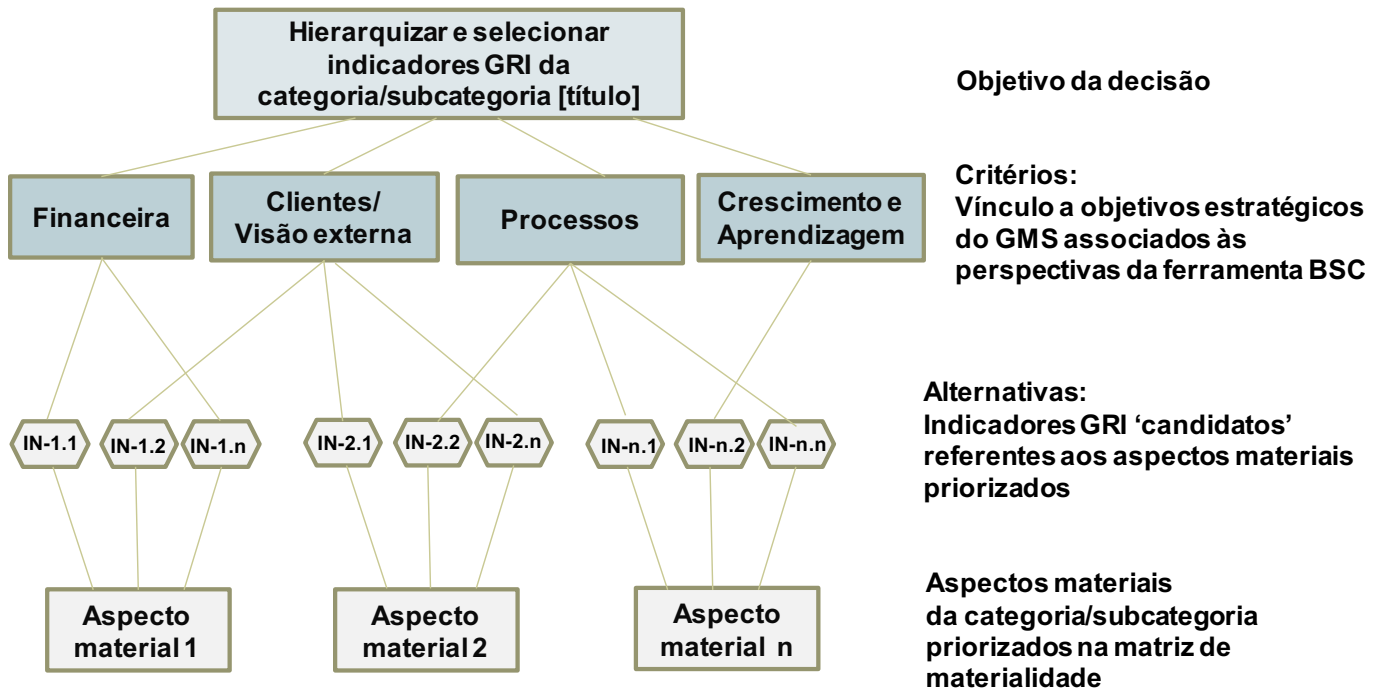

Figura 4.3 - Estrutura hierárquica a ser adotada pelo GMS na etapa 4 do modelo Fonte: Elaboração própria.

Conforme a figura 4.3, o objetivo da decisão é hierarquizar e selecionar os indicadores GRI 'candidatos' de cada categoria/subcategoria da sustentabilidade.

Para cada categoria/subcategoria, o GMS deverá construir as respectivas estruturas hierárquicas, conforme o esquema genérico representado na figura 4.3. Serão no total seis desenhos de estruturas hierárquicas: (i) categoria econômica; (ii) categoria ambiental; (iii) subcategoria social - práticas trabalhistas e trabalho decente; (iv) subcategoria social - direitos humanos; (v) subcategoria social sociedade; e (vi) subcategoria social - responsabilidade sobre o produto.

Cabe destacar que os blocos situados na parte inferior da figura 4.3 não constituem alternativas subordinadas aos indicadores GRI candidatos. Eles

\footnotetext{
${ }^{4}$ Os indicadores GRI 'candidatos' referem-se àqueles indicadores associados aos aspectos materiais de cada categoria/subcategoria priorizados no processo de construção das respectivas matrizes de materialidade (etapa 2 deste modelo).
} 
representam os aspectos materiais da categoria/subcategoria em foco, que foram priorizados na etapa 2 - construção da matriz de materialidade. A cada aspecto material priorizado, deverão ser associados todos os indicadores GRI indicados pelas Diretrizes G4 da GRI (ver quadro 3.1 e descrições dos indicadores - anexo 1).

As estruturas hierárquicas resultantes das categorias/subcategorias da sustentabilidade constituirão os insumos para a etapa 4 - hierarquização e seleção de indicadores GRI, com uso do método híbrido AHP-TOPSIS.

\subsection{4. \\ Etapa 4: Hierarquização e seleção de indicadores GRI por categoria/subcategoria da sustentabilidade: uso do método AHP- TOPSIS}

A exemplo da etapa 2, a hierarquização e seleção de indicadores GRI deverá ser conduzida por categoria/subcategoria da sustentabilidade. Para tal, propõe-se o emprego de um método híbrido multicritério, que combina o método AHP para determinação dos pesos dos critérios com o método TOPSIS para a hierarquização propriamente dita das alternativas (indicadores GRI 'candidatos' por categoria/subcategoria).

Isso posto, o primeiro passo é a consulta à estrutura hierárquica das Diretrizes GRI para identificar os indicadores GRI 'candidatos' associados aos aspectos materiais da categoria/subcategoria, que foram priorizados na etapa 2 do modelo.

A partir da identificação dos indicadores GRI 'candidatos' referentes à uma determinada categoria/subcategoria, o próximo passo é classificar esses indicadores segundo as perspectivas da ferramenta BSC, consultando a proposta de classificação apresentada no quadro 4.1.

A título de ilustração, toma-se o exemplo da categoria 'Econômica' apresentado nas tabelas 4.1 a 4.4. De acordo com os resultados apresentados, os aspectos materiais priorizados na etapa 2 (segundo as visões dos stakeholders internos e externos) foram: (i) AM1 - 'Desempenho econômico'; e (ii) AM2 'Presença no mercado'. Na sequência, identificaram-se os indicadores GRI correspondentes a esses dois aspectos, que foram classificados segundo as perspectivas da ferramenta BSC (conforme classificação proposta no quadro 4.1). Neste exemplo, identificaram-se seis indicadores (EC1 a EC6), que foram classificados da seguinte forma: (i) EC1, EC2 e EC4 - perspectiva 'Financeira'; (ii) EC6 - perspectiva 'Clientes/visão externa'; e (iii) EC3 e EC5 - perspectiva 
'Aprendizagem e crescimento'. Esses foram os chamados indicadores GRI 'candidatos'.

Uma vez classificados os indicadores GRI 'candidatos', o passo seguinte é empregar o método AHP para determinar os pesos dos critérios, isso porque para cada categoria/subcategoria os pesos dos critérios poderão variar. Por exemplo, para selecionar os indicadores GRI 'candidatos' da categoria 'Ambiental' o peso da perspectiva 'Processos' deverá em tese ser maior que a perspectiva 'Financeira'. Desse modo, constroem-se matrizes quadradas com as quatro perspectivas BSC para os julgamentos dos especialistas/gestores em relação à importância de uma perspectiva em relação às demais.

Prosseguindo-se com o exemplo didático, a matriz de comparação pareada dos critérios para a seleção de indicadores GRI 'candidatos' da categoria 'Econômica' é representada na tabela 4.6.

Tabela 4.6 - Exemplo de matriz de comparação pareada dos critérios para seleção dos indicadores GRI 'candidatos' da categoria 'Econômica'

\begin{tabular}{l|l|l|l|l}
\hline Perspectivas BSC (Critérios) & FI & VE & PR & AC \\
\hline FI: Financeira & $\mathbf{1}$ & 1 & 3 & 4 \\
\hline VE: Clientes /Visão externa & 1 & $\mathbf{1}$ & 3 & 4 \\
\hline PR: Processos & $1 / 3$ & $1 / 3$ & $\mathbf{1}$ & $1 / 2$ \\
\hline AC: Aprendizagem e crescimento & $1 / 4$ & $1 / 4$ & 2 & $\mathbf{1}$ \\
\hline
\end{tabular}

Fonte: Elaboração própria.

A tabela 4.7 mostra os pesos dados aos critérios, obtidos segundo especialistas do Programa Pós-MQI da PUC-Rio, e a 'Razão de Consistência' (RC) dos julgamentos realizados para este exemplo didático.

Tabela 4.7 - Grau de importância atribuída aos critérios para seleção dos indicadores GRI 'candidatos' da categoria 'Econômica'

\begin{tabular}{lll}
\hline Perspectivas BSC (Critérios) & Pesos & RC \\
\hline FI: Financeira & 0,382 & \\
\cline { 1 - 2 } VE: Clientes /Visão externa & 0,382 & Valor dentro do padrão \\
\cline { 1 - 2 } PR: Processos & $R C \leq=0,1$ \\
\cline { 1 - 2 } AC: Aprendizagem e crescimento & 0,105 & \\
\hline
\end{tabular}

Fonte: Elaboração própria.

Uma vez definidos os pesos dos critérios e classificados os indicadores GRI 'candidatos' de uma categoria/subcategoria, o próximo passo é construir uma matriz para aplicação do método TOPSIS. 
Para a análise quantitativa da seleção dos indicadores GRI 'candidatos' que deverão ser objeto do Relatório de Sustentabilidade do GMS, propõe-se a construção de seis matrizes correspondentes às categorias/subcategorias da sustentabilidade, como já mencionado nas etapas anteriores.

Essas matrizes são compostas pelos seguintes elementos:

- Linhas: contemplam todos os indicadores GRI associados aos aspectos materiais de cada categoria/subcategoria, que foram priorizados na etapa de construção da matriz de materialidade da categoria/subcategoria;

- Colunas: contém informações sobre os aspectos materiais e as perspectivas BSC associadas a esses indicadores GRI ‘candidatos'; e os pesos (grau de importância) dos critérios de seleção.

O preenchimento deverá ser conduzido pelos gestores e especialistas internos do GMS que participarão também das etapas anteriores, utilizando-se a técnica TOPSIS, descrita em detalhe no apêndice 1.

A título de ilustração, prossegue-se com o exemplo didático referente à seleção de indicadores GRI 'candidatos' da categoria 'Econômica' no contexto corporativo de um GMS fictício (tabelas 4.8 a 4.12).

Com a tabela 4.8 preenchida, emprega-se o método TOPSIS para hierarquização dos indicadores GRI candidatos e posterior seleção para fins de elaboração do Relatório de Sustentabilidade do GMS e inclusão no seu sistema de monitoramento e avaliação de desempenho em sustentabilidade (tabelas 4.9 a 4.12 ). 
Tabela 4.8 - Matriz de avaliação quantitativa de indicadores GRI 'candidatos' da categoria 'Econômica'

\begin{tabular}{|c|c|c|c|c|c|c|c|c|c|c|c|c|c|c|}
\hline \multirow{3}{*}{$\begin{array}{l}\text { Indicadores GRI } \\
\text { 'candidatos' }\end{array}$} & \multicolumn{2}{|c|}{$\begin{array}{l}\text { Aspectos materiais } \\
\text { priorizados }\end{array}$} & \multicolumn{4}{|c|}{ Perspectivas BSC } & \multicolumn{8}{|c|}{ Critérios para hierarquização e seleção dos indicadores* } \\
\hline & \multirow[t]{2}{*}{$\begin{array}{l}\text { Desempenho } \\
\text { econômico }\end{array}$} & \multirow[t]{2}{*}{$\begin{array}{l}\text { Presença no } \\
\text { mercado }\end{array}$} & \multirow[t]{2}{*}{$\mathrm{FI}$} & \multirow[t]{2}{*}{ VE } & \multirow[t]{2}{*}{ PR } & \multirow[t]{2}{*}{ AC } & \multicolumn{2}{|c|}{ Fl: Financeira } & \multicolumn{2}{|c|}{$\begin{array}{l}\text { VE: Clientes/ } \\
\text { Visão externa }\end{array}$} & \multicolumn{2}{|c|}{ PR: Processos } & \multicolumn{2}{|c|}{$\begin{array}{c}\text { AC: } \\
\text { Aprendizagem e } \\
\text { Crescimento }\end{array}$} \\
\hline & & & & & & & $\begin{array}{c}\text { Atende } \\
* *\end{array}$ & Peso & $\begin{array}{c}\text { Atende } \\
* *\end{array}$ & Peso & $\begin{array}{c}\text { Atende } \\
* *\end{array}$ & Peso & $\begin{array}{c}\text { Atende } \\
* *\end{array}$ & Peso \\
\hline $\begin{array}{l}\text { EC1: Valor econômico } \\
\text { direto gerado e distribuído }\end{array}$ & $\mathrm{x}$ & & $\mathrm{x}$ & & & & 7 & 0,382 & 1 & 0,382 & 1 & 0,105 & 1 & 0,130 \\
\hline $\begin{array}{l}\text { EC2: Implicações } \\
\text { financeiras e outros riscos } \\
\text { e oportunidades para as } \\
\text { atividades do GMS em } \\
\text { decorrência de mudanças } \\
\text { climáticas }\end{array}$ & $\mathrm{x}$ & & $x$ & & & & 7 & 0,382 & 1 & 0,382 & 1 & 0,105 & 3 & 0,130 \\
\hline $\begin{array}{l}\text { EC3: Cobertura das } \\
\text { obrigações previstas no } \\
\text { plano de pensão de } \\
\text { benefício definido do GMS }\end{array}$ & $\mathrm{x}$ & & & & & $\mathrm{x}$ & 1 & 0,382 & 1 & 0,382 & 1 & 0,105 & 1 & 0,130 \\
\hline $\begin{array}{l}\text { EC4: Assistência financeira } \\
\text { recebida do governo }\end{array}$ & $x$ & & $x$ & & & & 5 & 0,382 & 1 & 0,382 & 1 & 0,105 & 1 & 0,130 \\
\hline $\begin{array}{l}\text { EC5: Variação da } \\
\text { proporção do salário mais } \\
\text { baixo, discriminado por } \\
\text { gênero, comparado ao } \\
\text { salário mínimo local em } \\
\text { unidades operacionais } \\
\text { importantes }\end{array}$ & & $x$ & & & & $x$ & 1 & 0,382 & 1 & 0,382 & 1 & 0,105 & 5 & 0,130 \\
\hline $\begin{array}{l}\text { EC6: Proporção de } \\
\text { membros da alta direção } \\
\text { contratados na } \\
\text { comunidade local em } \\
\text { unidades operacionais } \\
\text { importantes }\end{array}$ & & $x$ & & $x$ & & & 1 & 0,382 & 5 & 0,382 & 1 & 0,105 & 1 & 0,130 \\
\hline
\end{tabular}

Notas: * Os critérios referem-se aos vínculos do indicador com um ou mais objetivos estratégicos do GMS na perspectiva do BSC em foco: $\mathrm{FI}$ - Financeira; VE Clientes/Visão externa; PR - Processos; AC - Aprendizagem e crescimento.

** A escala para os julgamentos dos indicadores "candidatos" em relação ao atendimento aos critérios são: 1 - nenhum vínculo ou vínculo muito fraco com um ou mais objetivos estratégicos da perspectiva em foco; 3 - vínculo fraco; 5 - vínculo moderado; 7 - vínculo forte; 9 - vínculo muito forte. 
Tabela 4.9 - Soluções ideais PIS e NIS para os critérios para hierarquização e seleção dos indicadores GRI da categoria 'Econômica'

\begin{tabular}{|l|l|l|}
\hline Critério & PIS & NIS \\
\hline FI- Financeira & 1 & 0,14 \\
\hline VE-Clientes/Visão externa & 1 & 0,20 \\
\hline PR- Processos & 1 & 1,00 \\
\hline $\begin{array}{l}\text { AC- Aprendizagem e } \\
\text { crescimento }\end{array}$ & 1 & 0,20 \\
\hline
\end{tabular}

Legenda: PIS - solução ideal positiva; NIS- solução ideal negativa.

Fonte: Elaboração própria.

Tabela 4.10 - Distâncias euclidianas (positivas e negativas) dos indicadores GRI da categoria 'Econômica'

\begin{tabular}{|l|l|l|}
\hline Descrição & $\begin{array}{l}\mathbf{d}^{+} \\
\text {(Benefícios) }^{+}\end{array}$ & $\begin{array}{l}\mathbf{d}^{-} \\
\text {(Custos) }\end{array}$ \\
\hline EC1: Valor econômico direto gerado e distribuído & 0,57 & 0,53 \\
\hline $\begin{array}{l}\text { EC2: Implicações financeiras e outros riscos e oportunidades } \\
\text { para as atividades do GMS em decorrência de mudanças } \\
\text { climáticas }\end{array}$ & 0,52 & 0,55 \\
\hline $\begin{array}{l}\text { EC3: Cobertura das obrigações previstas no plano de pensão } \\
\text { de benefício definido do GMS }\end{array}$ & 0,78 & 0,00 \\
\hline EC4: Assistência financeira recebida do governo & 0,60 & 0,35 \\
\hline $\begin{array}{l}\text { EC5: Variação da proporção do salário mais baixo, } \\
\text { discriminado por gênero, comparado ao salário mínimo } \\
\text { local em unidades operacionais importantes }\end{array}$ & 0,72 & 0,29 \\
\hline $\begin{array}{l}\text { EC6: Proporção de membros da alta direção contratados na } \\
\text { comunidade local em unidades operacionais importantes }\end{array}$ & 0,60 & 0,49 \\
\hline
\end{tabular}

Fonte: Elaboração própria.

A partir das distâncias euclidianas, deverão ser calculadas as proximidades relativas de cada indicador GRI da categoria 'Econômica' em relação à PIS $(\xi)$, cujos resultados encontram-se na tabela 4.11.

Tabela 4.11 - Proximidades relativas dos indicadores GRI 'candidatos' da categoria 'Econômica' em relação à PIS

\begin{tabular}{|l|l|}
\hline Indicador & $\begin{array}{l}\text { Proximidade } \\
\text { relativa § }\end{array}$ \\
\hline EC1: Valor econômico direto gerado e distribuído & 0,48 \\
\hline $\begin{array}{l}\text { EC2: Implicações financeiras e outros riscos e oportunidades para } \\
\text { as atividades do GMS em decorrência de mudanças climáticas }\end{array}$ & 0,52 \\
\hline $\begin{array}{l}\text { EC3: Cobertura das obrigações previstas no plano de pensão de } \\
\text { benefício definido do GMS }\end{array}$ & 0,00 \\
\hline EC4: Assistência financeira recebida do governo & 0,37 \\
\hline $\begin{array}{l}\text { EC5: Variação da proporção do salário mais baixo, discriminado } \\
\text { por gênero, comparado ao salário mínimo local em unidades } \\
\text { operacionais importantes }\end{array}$ & 0,28 \\
\hline $\begin{array}{l}\text { EC6: Proporção de membros da alta direção contratados na } \\
\text { comunidade local em unidades operacionais importantes }\end{array}$ & 0,45 \\
\hline
\end{tabular}

Fonte: Elaboração própria. 
A tabela 4.12 mostra os resultados da hierarquização dos indicadores GRI desta categoria, com o uso da técnica TOPSIS.

Tabela 4.12 - Hierarquização dos indicadores GRI 'candidatos' da categoria 'Econômica'

\begin{tabular}{|c|c|c|}
\hline Posição & Indicador & Proximidade relativa $\xi$ \\
\hline 10 & $\begin{array}{l}\text { EC2: Implicações financeiras e outros riscos e } \\
\text { oportunidades para as atividades do GMS em decorrência } \\
\text { de mudanças climáticas }\end{array}$ & 0,52 \\
\hline 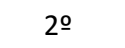 & EC1: Valor econômico direto gerado e distribuído & 0,48 \\
\hline 30 & $\begin{array}{l}\text { EC6: Proporção de membros da alta direção contratados } \\
\text { na comunidade local em unidades operacionais } \\
\text { importantes }\end{array}$ & 0,45 \\
\hline $4 \stackrel{0}{2}$ & EC4: Assistência financeira recebida do governo & 0,37 \\
\hline 50 & $\begin{array}{l}\text { EC5: Variação da proporção do salário mais baixo, } \\
\text { discriminado por gênero, comparado ao salário mínimo } \\
\text { local em unidades operacionais importantes }\end{array}$ & 0,28 \\
\hline 60 & $\begin{array}{l}\text { EC3: Cobertura das obrigações previstas no plano de } \\
\text { pensão de benefício definido do GMS }\end{array}$ & 0,00 \\
\hline
\end{tabular}

Fonte: Elaboração própria.

Os gestores do GMS deverão realizar os procedimentos da etapa 4 para todas as categorias/subcategorias das Diretrizes G4 da GRI. Depois de gerados resultados como os apresentados na tabela 4.12, os gestores do GMS deverão consolidar a relação dos indicadores GRI de todas as categorias/subcategorias para elaboração do Relatório e inclusão na sistemática de monitoramento e avaliação estratégica do desempenho em sustentabilidade do Grupo.

Deve-se ressaltar que no primeiro ciclo de aplicação do modelo objeto da presente pesquisa em um GMS, é possível que haja necessidade de revisar o processo de planejamento estratégico do Grupo para criação de um BSC sustentável, como abordado no capitulo 2. Se for observada a inexistência de objetivos estratégicos relacionados à melhoria de desempenho em sustentabilidade do Grupo, acredita-se que a própria aplicação do modelo em suas cinco etapas poderá contribuir para o pensamento estratégico do Grupo segundo a abordagem Triple Bottom Line, também discutida no capítulo 2.

\subsection{5.}

\section{Etapa 5: Elaboração das identidades dos indicadores selecionados e respectivas métricas}

Define-se no quadro 4.3 um metamodelo para especificar as identidades dos indicadores de sustentabilidade selecionados pelo GMS e suas respectivas métricas. 
Quadro 4.3 - Metamodelo para elaboração das identidades dos indicadores selecionados pelo GMS e respectivas métricas

\begin{tabular}{|c|c|}
\hline \multicolumn{2}{|l|}{ Caracterização do indicador } \\
\hline Nome & Nome atribuído ao indicador e sua respectiva sigla, se aplicável. \\
\hline Fórmula & Fórmula para cálculo do indicador. \\
\hline Unidade de medida & Unidade do indicador resultante. \\
\hline $\begin{array}{l}\text { Necessidade de } \\
\text { informação atendida }\end{array}$ & $\begin{array}{l}\text { Necessidade que motivou a seleção do indicador, diretamente relacionada } \\
\text { aos objetivos de monitoramento e avaliação estratégica da } \\
\text { sustentabilidade corporativa do GMS. }\end{array}$ \\
\hline Aplicabilidade & $\begin{array}{l}\text { Informação sobre o nível organizacional de mensuração (corporativo/ } \\
\text { setorial/empresas do Grupo). }\end{array}$ \\
\hline \multicolumn{2}{|c|}{ Faixas de valores do indicador } \\
\hline \multirow[t]{2}{*}{ Limites das faixas } & $\begin{array}{l}\text { Mínimo: limites inferior e superior dessa faixa a serem atribuídos para o } \\
\text { indicador. } \\
\text { Modesto: limites inferior e superior dessa faixa a serem atribuídos para o } \\
\text { indicador. }\end{array}$ \\
\hline & $\begin{array}{l}\text { Intermediário: limites inferior e superior dessa faixa a serem atribuídos } \\
\text { para o indicador. } \\
\text { Significante: limites inferior e superior dessa faixa a serem atribuídos para } \\
\text { o indicador. } \\
\text { Alto: limites inferior e superior dessa faixa a serem atribuídos para o } \\
\text { indicador. } \\
\text { Muito alto: limites inferior e superior dessa faixa a serem atribuídos para o } \\
\text { indicador. }\end{array}$ \\
\hline \multicolumn{2}{|l|}{ Coleta dos dados-base } \\
\hline Responsável & $\begin{array}{l}\text { Órgão/profissional responsável pela coleta dos dados-base para a apuração } \\
\text { do indicador. }\end{array}$ \\
\hline Fonte & $\begin{array}{l}\text { Sistemas de informação gerencial (SIG) - no nível corporativo do Grupo e } \\
\text { das empresas que integram o Grupo. }\end{array}$ \\
\hline Periodicidade & $\begin{array}{l}\text { Periodicidade com que deve ser realizada a coleta dos dados-base para a } \\
\text { medição ou evento que sinalize a necessidade de nova coleta. }\end{array}$ \\
\hline Procedimento & $\begin{array}{l}\text { Instruções sobre as atividades que devem ser realizadas para se obter os } \\
\text { dados-base para o indicador, incluindo eventuais aspectos de controle de } \\
\text { qualidade. }\end{array}$ \\
\hline \multicolumn{2}{|c|}{ Metodologia de cálculo para apuração do indicador } \\
\hline Responsável & $\begin{array}{l}\text { Órgão/profissional responsável pelo cálculo (apuração) do indicador por } \\
\text { meio da aplicação da fórmula sobre os dados-base. }\end{array}$ \\
\hline Periodicidade & $\begin{array}{l}\text { Periodicidade com que deve ser realizado o cálculo do indicador ou evento } \\
\text { que sinalize a necessidade de novo cálculo. Em geral, a periodicidade de } \\
\text { cálculo coincide com a periodicidade de análise. }\end{array}$ \\
\hline Procedimento & $\begin{array}{l}\text { Instruções sobre como ter acesso aos dados-base coletados anteriormente } \\
\text { e sobre como efetuar o cálculo da medição, incluindo eventuais aspectos } \\
\text { de controle de qualidade. }\end{array}$ \\
\hline $\begin{array}{l}\text { Período de abrangência do } \\
\text { cálculo }\end{array}$ & $\begin{array}{l}\text { Refere-se ao período de tempo abrangido na apuração. } \\
\text { Mensal: apuração do indicador com base em dados coletados durante um } \\
\text { mês. } \\
\text { Semestral: apuração do indicador com base em dados coletados durante } \\
\text { um semestre. } \\
\text { Anual: apuração do indicador com base em dados coletados durante um } \\
\text { Acumulado: apuração do indicador com base nos dados coletados desde o } \\
\text { início até o último mês do período considerado para a coleta; } \\
\text { Projetado: apuração do indicador com base nos dados coletados desde o } \\
\text { início até o final do período considerado, mais a previsão da medição em } \\
\text { períodos subsequentes. } \\
\text { Valor individual: apuração do indicador com base nos dados coletados } \\
\text { correspondentes ao valor individual da medição. } \\
\text { Outros períodos: bienal, trienal, etc. }\end{array}$ \\
\hline \multicolumn{2}{|l|}{ Análise pós-cálculo } \\
\hline Responsável & $\begin{array}{l}\text { Órgão/profissional responsável por analisar o valor do indicador apurado e } \\
\text { sugerir ações gerenciais para tratamento dos desvios. }\end{array}$ \\
\hline Procedimento & $\begin{array}{l}\text { Instruções sobre como efetuar a análise do indicador obtido, incluindo o } \\
\text { significado de faixas de valores possíveis de medição. }\end{array}$ \\
\hline $\begin{array}{l}\text { Possíveis causas de } \\
\text { desvios }\end{array}$ & Indicação de possíveis causas de desvios no processo de medição. \\
\hline
\end{tabular}




\begin{tabular}{|l|l|}
\hline Possíveis ações gerenciais & $\begin{array}{l}\text { Sugestões de possíveis ações gerenciais para tratamento dos desvios no } \\
\text { processo de medição. }\end{array}$ \\
\hline Disponibilização dos resultados para tomada de decisão \\
\hline Divulgação & $\begin{array}{l}\text { Instrumento utilizado para apresentar aos interessados o valor do } \\
\text { indicador, sua análise e ações gerenciais propostas. }\end{array}$ \\
\hline Segurança da informação & $\begin{array}{l}\text { Local de armazenamento dos valores apurados para o indicador } \\
\text { juntamente com suas análises. }\end{array}$ \\
\hline Local de armazenamento & $\begin{array}{l}\text { Órgãos e setores que devem possuir acesso aos resultados e às análises do } \\
\text { indicador. }\end{array}$ \\
\hline Nível de acesso & $\begin{array}{l}\text { Procedimentos adicionais para garantia da integridade dos dados } \\
\text { coletados, apurados e analisados. }\end{array}$ \\
\hline Integridade dos dados
\end{tabular}

Fonte: Elaboração própria.

\section{4.}

Subsídios para elaboração de um suplemento orientativo para grupos multissetoriais pela GRI - G4 Multisectorial Disclosures

Em 2016, a GRI anunciou que planejava atualizar e expandir as publicações setoriais e dedicar mais atenção nesse processo a partir de 2017. As orientações setoriais (G4 Multisectorial Disclosures) são desenvolvidas por grupos de trabalho internacionais, compostos por voluntários oriundos de diversas partes interessadas, que respondem ao Comitê Técnico Consultivo da GRI. Cabe ressaltar que a GRI estimula manifestações de interesse, entrevistando as partes interessadas e buscando ativamente especialistas setoriais para aumentar a representatividade nesses grupos.

O objetivo desta seção é endereçar subsídios baseados nos diferenciais e descobertas da presente pesquisa para discussão e futura elaboração de um Suplemento Orientativo para Grupos Multissetoriais (GMSs) por parte da GRI, ou seja, G4 Multisectorial Disclosures.

O monitoramento e a avaliação estratégica de desempenho em sustentabilidade apresentam desafios especiais para GMSs, pela dinâmica, complexidade e incerteza dos diversos ambientes socioprodutivos e que atuam e interagem. Como proposto neste capítulo, o modelo conceitual tem como pilar principal a integração de métodos multicritério de apoio à decisão a uma ferramenta consagrada de gerenciamento estratégico (Balanced Scorecard), visando a melhoria contínua do processo de elaboração dos Relatórios da Sustentabilidade de GMSs.

A figura 4.4, a seguir, apresenta o modelo proposto pela GRI em seu Manual de Implementação das Diretrizes G4 (GRI, 2015). 


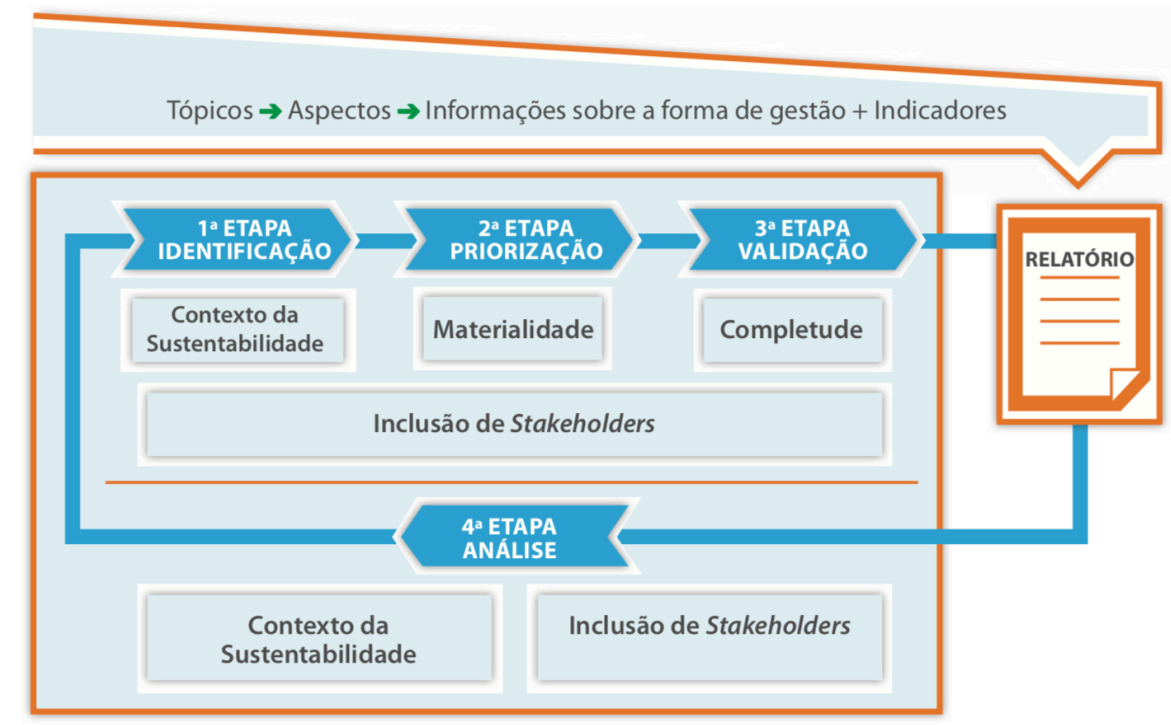

Figura 4.4 -Visão geral do processo de elaboração do Relatório de Sustentabilidade, segundo a GRI

Fonte: GRI (2015).

Como as quatro etapas propostas pela GRI (Figura 4.4) são aplicáveis para GMSs, independentemente das suas respectivas composições e estruturas, optou-se por adotar esta estrutura para elaborar e endereçar à GRI subsídios para elaboração de um suplemento orientativo para grupos multissetoriais.

Inicialmente, o GMS pode verificar a existência de publicações setoriais que contemplem parte ou até mesmo a sua estrutura como um todo. Os suplementos setoriais existentes servirão de guias e, nas partes não contempladas, essas quatro etapas propostas na figura 4.4 são aplicáveis na modelagem.

$\mathrm{Na}$ primeira etapa (identificação) preocupa-se com a identificação dos Aspectos e outros tópicos materiais. A segunda etapa (priorização) focaliza a priorização dos aspectos materiais.

O ponto central da terceira etapa (validação) refere-se à identificação das informações a serem incluídas no relatório da sustentabilidade.

A quarta etapa (análise) propõe um envolvimento direto da organização através dos seus gestores na análise dos resultados medidos e relatados, com foco no próximo ciclo de emissão do relatório da sustentabilidade.

Nesta pesquisa, recomenda-se que o processo de definição dos stakeholders externos (etapa 1) pelo GMS seja conduzido por categoria da sustentabilidade: (i) econômica, (ii) ambiental; e (iii) social. O benefício direto é o aumento da qualidade associada aos focos de julgamentos e decisões atrelados aos aspectos materiais relacionados às respectivas categorias da sustentabilidade. 
Para a segunda etapa (priorização), recomenda-se que o GMS adote o método multicritério AHP para a priorização dos aspectos materiais por categoria/subcategoria da sustentabilidade, por parte dos stakeholders internos e externos, respectivamente. Com esse procedimento, o GMS poderá verificar o balanceamento dos aspectos de todas as categorias/subcategorias na sua matriz de materialidade corporativa e o alinhamento da visão estratégica do Grupo com os interesses de seus stakeholders externos.

$\mathrm{Na}$ terceira etapa (validação), recomenda-se a integração da estrutura de indicadores GRI à estratégia de sustentabilidade corporativa, por exemplo, por meio da construção de mapas estratégicos (BSC sustentáveis), com objetivo de alinhar os esforços relacionados à melhoria do desempenho em sustentabilidade do GMS a objetivos estratégicos deliberadamente expressos na estratégia corporativa do Grupo. Os benefícios para o GMS incluem: (i) a criação de uma visão compartilhada dos objetivos estratégicos de sustentabilidade a serem atingidos em todos os níveis da organização; (ii) a integração dos indicadores GRI ao gerenciamento estratégico do GMS e de suas empresas, relacionando-os aos objetivos estratégicos de sustentabilidade incluídos intencionalmente nos respectivos mapas estratégicos (objetivos vinculados às perspectivas $\mathrm{BSC}$, no caso do modelo aqui proposto).

Ainda nesta etapa (validação), recomenda-se o emprego do método híbrido AHP-TOPSIS em dois momentos do modelo conceitual proposto nesta pesquisa: (i) na definição dos pesos dos critérios de seleção, aqui definidos como o vínculo dos indicadores GRI a um ou mais objetivos estratégicos do GMS, associados às perspectivas BSC (etapa 4 do modelo proposto). O método TOPSIS deverá ser empregado para a seleção propriamente dita dos indicadores 'candidatos' GRI.

A última recomendação refere-se à necessidade do alinhamento metodológico dos procedimentos adotados no nível corporativo com aqueles empregados pelas empresas do GMS (por setor de atuação do Grupo). Este alinhamento poderá ser facilitado pela adoção da ferramenta BSC, que inclui a construção de mapas estratégicos - nível corporativo e das empresas - e de painéis de contribuição das empresas do Grupo em relação a cada um dos indicadores GRI selecionados no nível corporativo.

Finalmente, acredita-se que o modelo conceitual proposto possa ser replicado em processos de avaliação de desempenho em sustentabilidade de grupos multissetoriais no Brasil e no exterior. 


\section{5 \\ Demonstração da aplicabilidade do modelo no âmbito do Grupo Algar}

Apresentam-se e discutem-se os resultados do estudo empírico no âmbito do Grupo Algar, que permitiram demonstrar a aplicabilidade do modelo proposto no capítulo anterior, focalizando-se somente a categoria 'ambiental' das Diretrizes G4 GRI. O desenvolvimento deste estudo teve como resultado final a aplicação do modelo no contexto corporativo multissetorial do Grupo.

\section{1.}

Definição das questões e proposições do estudo empírico

Enuncia-se a questão principal deste estudo empírico como sendo:

“Como deve ser estruturado um sistema de monitoramento e avaliação estratégica de desempenho em sustentabilidade para o Grupo Algar, a partir de uma abordagem metodológica que alinhe a seleção de indicadores e métricas das Diretrizes G4 da GRI com objetivos estratégicos e à visão de longo prazo desses grupos?". Em outras palavras, como o Grupo Algar poderá se beneficiar dessa nova sistemática vista como ferramenta de gerenciamento estratégico da sustentabilidade corporativa, além da função de comunicar e demonstrar seus resultados para os diversos stakeholders por meio da publicação anual de seu Relatório de Sustentabilidade?

Com os resultados deste estudo empírico, pretende-se demonstrar a aplicabilidade do modelo conceitual proposto no capítulo 4, respondendo as seguintes questões específicas relacionadas ao contexto corporativo do Grupo Algar, a saber:

- Como selecionar os stakeholders externos do Grupo Algar, que deverão participar dos processos de construção das respectivas matrizes de materialidade (por categoria/subcategoria) e da consolidação da matriz de materialidade do Grupo como um todo?

- Como aperfeiçoar a prática atual de seleção dos aspectos materiais de cada categoria da sustentabilidade, com uso do método AHP? 
- Como integrar a estrutura de indicadores GRI por categoria/subcategoria da sustentabilidade, conforme definidos nas Diretrizes G4 da GRI com a ferramenta de gerenciamento estratégico conhecida como Balanced Scorecard?

- Como selecionar indicadores por categoria/subcategoria da sustentabilidade com uso do método híbrido multicritério AHP-TOPSIS e quais os diferenciais do emprego deste método híbrido em relação aos procedimentos que vêm sendo adotados pelo Grupo Algar?

\section{2. \\ Delimitação e caracterização da unidade de análise e seu contexto organizacional}

Busca-se nesta seção delimitar e caracterizar a unidade de análise do estudo de caso em foco e seu contexto organizacional, apresentando o perfil institucional do Grupo Algar e seu atual processo de elaboração do Relatório da Sustentabilidade em nível corporativo.

\subsection{1.}

\section{Unidade de análise}

A unidade de análise deve considerar o modo como o problema de pesquisa foi definido. Dessa forma, analisando-se o problema de pesquisa estabeleceu-se que a unidade de análise deste estudo de caso é o monitoramento e avaliação estratégica do desempenho em sustentabilidade do Grupo Algar no nível corporativo multissetorial.

A seguir, apresentam-se de forma resumida o contexto organizacional, no qual este estudo empírico foi desenvolvido - o GMS Algar e seu Relatório de Sustentabilidade no contexto corporativo.

\subsection{2.}

\section{Contexto organizacional: o Grupo Algar}

O Grupo Algar é um grupo multissetorial brasileiro, fundado em 1930 pelo Comendador Alexandrino Garcia. Conta com o talento de 23 mil associados (funcionários) para atender mais de 2 milhões de clientes com faturamento anual de aproximadamente R 5 bilhões (em torno de US\$ 1,5 bilhão/ano).

O Grupo Algar tem como missão "Desenvolver relacionamentos e soluções inovadoras que gerem negócios sustentáveis com valor percebido”. Seu propósito 
é "Gente servindo gente”. Seus valores são: (i) cliente, nossa razão de existir; (ii) integridade; (iii) valorização dos talentos humanos; (iv) empreendedorismo; (v) sustentabilidade.

A Algar é um GMS com atuação em todo o território nacional e alguns países da América Latina. Possuiu uma a visão global onde a diversificação de seus negócios é uma opção estratégica: investe em negócios com alto potencial de crescimento, com foco em setores onde tem grande experiência, como Telecom/TI e Agro. Oferece soluções para empresas e pessoas por meio da atuação nos seguintes setores:

- TIC - Tecnologia da Informação \& Comunicações: empresas Algar Telecom e Algar Tech;

- Agro: empresas Algar Agro e Algar Farming;

- Serviços: Algar Segurança e Comtec;

- Turismo: Rio Quente Resorts.

Alguns investimentos adicionais são tratados em uma área chamada "Algar Ventures" e engloba iniciativas ou investimentos em fase de consolidação como a empresa Alsol na área de energias renováveis e também iniciativas de investimentos via aquisições ou programa específico junto a startups.

Desde 1989, o Grupo Algar adota um modelo de gestão próprio, chamado de 'Empresa-Rede', que tem como principal característica a gestão participativa em todas as esferas, com estímulo ao comprometimento e a autonomia com responsabilidade, permitindo a cada colaborador, independentemente do nível hierárquico, acompanhar e ter participação significativa nas decisões que pautam o rumo dos negócios de todo o Grupo Algar.

Para facilitar a gestão deste processo participativo, o modelo considera as empresas do Grupo como unidades conhecidas como 'Centros de Resultado'. Com suas metas e orçamentos, cada um desses 'Centros' contribui para a implantação do Plano Estratégico do Grupo, baseada na ferramenta Balanced Scorecard.

A partir da aprovação dos orçamentos, as empresas controladas são autônomas para executar seus planos e estratégias de negócio. A Alta Liderança do Grupo Algar administra estrategicamente os 'Centros de Resultado', alinhando-os às estratégias e metas estabelecidas, em concordância com o Conselho de Administração. Da mesma forma, o modelo de gestão 'Empresa-Rede' é replicado em cada uma das empresas Algar. 
A estratégia de crescimento do Grupo Algar expressa claramente o direcionamento para negócios que criem valor para seus stakeholders. O Grupo adota a metodologia Value Based Management (VBM) e, desde 2016, vem implantando um "Programa de Priorização de Projetos Estratégicos (PPE). Este Programa endereça as decisões de investimentos para o nível corporativo, prevalecendo a visão do que será mais significativo para o Grupo e não apenas para uma empresa ou um setor de atuação do Grupo.

Como grupo multissetorial, deseja reforçar seu papel estratégico, priorizando investimentos com maior potencial de crescimento e criação de valor para seus stakeholders. Ao considerar a carteira diversificada de negócios, com atuação multissetorial, o Grupo Algar prepara-se para dar continuidade ao seu processo de expansão multissetorial, de forma sustentável.

Desde 2011, o Grupo Algar adota as Diretrizes GRI para elaboração de seus Relatórios de Sustentabilidade. Em 2014, passou a seguir as Diretrizes G4 da GRI com Relato Essencial. As empresas Algar Telecom e Algar Agro também publicam seus Relatórios de Sustentabilidade.

\section{3. \\ Coleta e formatação de dados}

Antes de se iniciar a modelagem propriamente dita, cujos resultados foram apresentados no capítulo anterior, realizaram-se dez entrevistas no período de 17 e 23 de agosto de 2017 com representantes da Alta Liderança e gestores de primeira linha do Grupo Algar, com o objetivo de levantar as expectativas e pontos para melhoria referentes aos procedimentos atualmente adotados na elaboração dos Relatórios de Sustentabilidade do Grupo, que são publicados e divulgados anualmente (ver apêndice 1).

O modelo conceitual proposto nesta pesquisa levou em consideração os resultados dessas entrevistas e análises posteriores de Relatórios de Sustentabilidade de grupos multissetoriais, como General Electric (GE) e Siemens, além dos referenciais teórico e normativo apresentados nos capítulos iniciais.

No nível corporativo multissetorial, as entrevistas foram realizadas com: (i) o Presidente; (ii) a Vice-Presidente de Gente; (iii) o Vice-Presidente de Estratégia e Inovação; (iv) a Vice-Presidente de Finanças, também responsável pela emissão do Relatório da Sustentabilidade; e (v) duas representantes do Instituto Algar. 
Além das entrevistas no nível corporativo, foram ainda realizadas entrevistas com gestores das seguintes empresas do Grupo: (i) Alsol; (ii) Algar Telecom; (iii) Algar Tech; (iv) Algar Farming/Agro; e (v) Rio Quente Resorts. A agenda, roteiro e sínteses das entrevistas encontram-se no apêndice 2.

Com o objetivo de propor e demonstrar empiricamente a aplicabilidade do modelo proposto no contexto corporativo multissetorial do Grupo Algar, realizaram-se no período de 07 e 09 de março de 2018 três reuniões, conforme as seguintes agendas: (i) Agenda 'Sustentabilidade', com participação da VicePresidente de Gente e representantes do Instituto Algar; (ii) Agenda 'Setorial Telecom', incluída neste ciclo de reuniões, por ser indicada internamente como a melhor prática de elaboração de Relatório de Sustentabilidade, dentre as empresas do Grupo; e (iii) Agenda 'Corporativa Multissetorial', com a participação do Presidente do Grupo, da Vice-Presidente de Finanças e responsável pela emissão do Relatório de Sustentabilidade, de gestores de todos os negócios do Grupo, com exceção do representante da Algar Farming/Agro, e de uma das gestoras do Instituto Algar (ver apêndice 3).

A pauta dessas reuniões incluiu: (i) apresentação dos objetivos da pesquisa de mestrado e contextualização do tema; (ii) apresentação dos objetivos da reunião e pauta, com os tópicos que seriam abordados; (iii) apresentação geral do modelo e proposta da aplicação prática no contexto corporativo do Grupo Algar.

A aplicação se deu de acordo com as etapas do modelo, a saber:

- Etapa 1: Definição dos stakeholders externos do Grupo Algar, em função dos critérios 'poder', 'legitimidade' e 'urgência';

- Etapa 2: Construção da matriz de materialidade, a partir da priorização dos aspectos materiais da categoria 'Ambiental', com uso do método AHP;

- Etapa 3: Definição da estrutura hierárquica para seleção dos indicadores de sustentabilidade de todas as categorias/subcategorias, integrando-se a estrutura GRI às quatro perspectivas da ferramenta Balanced Scorecard;

- Etapa 4: Hierarquização e seleção de indicadores GRI da categoria 'Ambiental', com uso do método AHP-TOPSIS.

Cabe destacar que o desenvolvimento do estudo empírico levou em consideração os resultados das referidas reuniões, a análise documental de publicações do Grupo Algar e de Relatórios de Sustentabilidade de Grupos Multissetoriais, como General Electric (GE) e Siemens, esses últimos utilizados 
como material de apoio para as reuniões. Os resultados gerados por ocasião dessas reuniões encontram-se reportados e discutidos na próxima seção.

\section{4.}

\section{Apresentação e discussão dos resultados da aplicação no nível corporativo multissetorial}

Apresentam-se e discutem-se os resultados da demonstração empírica da aplicabilidade do modelo conceitual no contexto corporativo do Grupo Algar, focalizando-se a categoria 'Ambiental'.

\subsection{1.}

\section{Etapa 1: Definição dos stakeholders do Grupo Algar}

A definição dos stakeholders do Grupo Algar no contexto corporativo ocorreu na reunião realizada no dia 09 de março de 2018, na sede do Grupo e contou com a participação do Presidente Executivo do Grupo, de representantes da alta administração, da área da sustentabilidade e das empresas presentes em cada um dos setores de atuação do Grupo Algar. Para tal, utilizou-se o formulário proposto no quadro 4.2 .

$\mathrm{Na}$ ocasião, a seleção dos principais stakeholders externos baseou-se na pontuação alcançada pelos representantes de cada grupo, priorizando-se os de maior pontuação em cada grupo, e como resultado, deverão ser convidados para o próximo ciclo de elaboração do Relatório de Sustentabilidade e de revisão do Mapa Estratégico do Grupo (contexto corporativo), os representantes dos grupos de stakeholders com pontuação superior.

Como destacado na tabela 5.1, os fornecedores selecionados por grupo de stakeholders foram:

- Clientes: Bradesco e Bovespa;

- Investidores: Família Garcia;

- Fornecedores: Huawei e Cemig;

- Comunidades: Associações Comerciais e Industriais;

- Governo: Agências reguladoras e Secretaria da Fazenda de Minas Gerais;

- Universidades e Instituições de C\&T: Universidade Federal de Uberlândia e Fundação Dom Cabral;

- Mídias: Facebook;

- Grupos Especiais: Instituto Brasileiro de Governança Corporativa (IBGC). 
Tabela 5.1 - Definição dos stakeholders externos do Grupo Algar no contexto corporativo

\begin{tabular}{|c|c|c|c|c|c|c|c|c|c|c|c|c|}
\hline \multirow{4}{*}{ Tipo } & \multirow{4}{*}{$\begin{array}{l}\text { Grupos de } \\
\text { stakeholders }\end{array}$} & \multirow{4}{*}{ Principais stakeholders de cada grupo } & \multicolumn{9}{|c|}{ Critérios de seleção } & \multirow{4}{*}{ Total } \\
\hline & & & \multicolumn{3}{|c|}{ Poder* } & \multicolumn{3}{|c|}{ Legitimidade** } & \multicolumn{3}{|c|}{ Urgência*** } & \\
\hline & & & Baixo & Médio & Alto & Baixa & Média & Alta & Baixa & Média & Alta & \\
\hline & & & \begin{tabular}{|l|}
$1]$ \\
\end{tabular} & [3] & [5] & {$[1]$} & [3] & [5] & [1] & [3] & [5] & \\
\hline \multirow{12}{*}{ 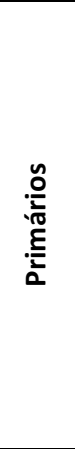 } & \multirow{3}{*}{ Clientes } & Grupo Martins & & & 5 & & & 5 & & 3 & & 13 \\
\hline & & Bradesco & & & 5 & & & 5 & & & 5 & 15 \\
\hline & & BOVESPA & & & 5 & & & 5 & & & 5 & 15 \\
\hline & \multirow{3}{*}{ Investidores } & Fundo GIC & & 3 & & & 3 & & & & 5 & 11 \\
\hline & & Bradesco & & 3 & & & 3 & & & & 5 & 11 \\
\hline & & Família Garcia & & & 5 & & & 5 & & & 5 & 15 \\
\hline & \multirow{3}{*}{ Fornecedores } & Huawei & & & 5 & & 3 & & & & 5 & 13 \\
\hline & & Canadian Solar & & 3 & & & 3 & & & 3 & & 9 \\
\hline & & Cemig & & & 5 & & & 5 & & & 5 & 15 \\
\hline & \multirow{3}{*}{ Comunidades } & CORU - Coop. Recicladores de Uberlândia & & 3 & & & 3 & & & 3 & & 9 \\
\hline & & Associação de moradores & & 3 & & & 3 & & & 3 & & 9 \\
\hline & & Associações Comerciais e Industriais & & 3 & & & 3 & & & & 5 & 11 \\
\hline \multirow{12}{*}{ 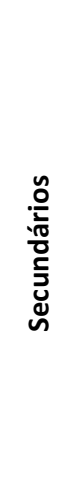 } & \multirow{3}{*}{ Governo } & Agências Reguladoras & & & 5 & & & 5 & & & 5 & 15 \\
\hline & & Prefeitura Uberlândia & & & 5 & & & 5 & & 3 & & 13 \\
\hline & & Secretaria da Fazenda de Minas Gerais & & & 5 & & & 5 & & & 5 & 15 \\
\hline & \multirow{3}{*}{$\begin{array}{l}\text { Universidades e } \\
\text { Instituições de } \\
\text { C\&T }\end{array}$} & Universidade Federal de Uberlândia & & & 5 & & & 5 & & & 5 & 15 \\
\hline & & Fundação Dom Cabral & & & 5 & & & 5 & & & 5 & 15 \\
\hline & & FGV/SP & & & 5 & & & 5 & & 3 & & 13 \\
\hline & \multirow{3}{*}{ Mídias } & Facebook & & & 5 & & & 5 & & & 5 & 15 \\
\hline & & TV Integração & & & 5 & & & 5 & & 3 & & 13 \\
\hline & & Linkedin & & & 5 & & & 5 & & 3 & & 13 \\
\hline & \multirow{3}{*}{$\begin{array}{l}\text { Grupos especiais } \\
\text { (citar) }\end{array}$} & HSM Management & & 3 & & & 3 & & & 3 & & 9 \\
\hline & & $\begin{array}{l}\text { IBGC - Instituto Brasileiro de Governança } \\
\text { Corporativa }\end{array}$ & & 3 & & & & 5 & & 3 & & 11 \\
\hline & & Company Circle & & 3 & & & 3 & & & 3 & & 9 \\
\hline
\end{tabular}

Notas: $\left({ }^{*}\right)$ - relacionado à obrigação da organização fazer algo que não seria feito sem ser solicitado pelo stakeholder;

${ }^{(* *)}$ - relacionada com a percepção pela organização de que as ações empreendidas pelo stakeholder são desejáveis, apropriadas a um sistema social de normas, valores e crenças;

$(* * *)$ - relacionada com a necessidade da velocidade de resposta da organização em relação à demanda do stakeholder.

Fonte: Elaboração própria, a partir dos resultados da reunião com gestores do Grupo Algar. 


\subsection{2.}

Etapa 2: Construção da matriz de materialidade da categoria 'Ambiental' com uso do método AHP: priorização dos aspectos materiais ambientais

Como abordado no capítulo 4, o método AHP descrito no apêndice 1 foi o método de escolha para a hierarquização dos aspectos materiais da categoria 'Ambiental', nas visões dos stakeholders internos e externos. Neste caso, para a aplicação do método AHP, foram consultados representantes da Alta Liderança do Grupo Algar e gestores de diversas empresas do Grupo, conforme mencionado no item 5.3.

As comparações pareadas dos 12 aspectos materiais da categoria 'Ambiental' foram realizadas em dois momentos. No primeiro momento, os julgamentos foram realizados pelos stakeholders internos, visando avaliar a significância dos impactos dos aspectos materiais da categoria em foco para o Grupo Algar.

Em um segundo momento, devido às limitações logísticas para envolvimento dos stakeholders externos, os julgamentos foram conduzidos pelos mesmos participantes da reunião, que se colocaram na perspectiva dos stakeholders externos destacados na tabela 5.1, simulando os julgamentos em relação à influência dos aspectos materiais da categoria 'Ambiental' sobre as avaliações e decisões desses stakeholders.

As tabelas 5.2 e 5.3 mostram as matrizes quadradas e recíprocas, preenchidas com os resultados das comparações pareadas dos aspectos materiais da categoria 'Ambiental', visando a plotagem dos 12 aspectos na matriz de materialidade da categoria em foco ('Ambiental').

Com as matrizes já preenchidas (tabelas 5.2 e 5.3), utilizou-se o sistema computacional IPÊ, versão 1.0, para o cálculo do grau de importância dos aspectos materiais e da razão de consistência (tabelas 5.4 e 5.5), visando a plotagem dos 12 aspectos na matriz de materialidade da categoria 'Ambiental', relativa ao contexto corporativo do Grupo Algar. 
Tabela 5.2- Comparação pareada dos aspectos materiais da categoria 'Ambiental': visão dos stakeholders internos

\begin{tabular}{|c|c|c|c|c|c|c|c|c|c|c|c|c|}
\hline $\begin{array}{l}\text { Aspectos materiais da } \\
\text { categoria 'Ambiental' }\end{array}$ & A5 & A6 & A7 & A8 & A9 & A10 & A11 & A12 & A13 & A14 & A15 & A16 \\
\hline AM5: Materiais & 1 & $1 / 3$ & $1 / 2$ & 1 & $1 / 2$ & $1 / 2$ & 2 & $1 / 4$ & 1 & $1 / 2$ & 2 & 2 \\
\hline AM6: Energia & 3 & 1 & 2 & 4 & 1 & 2 & 4 & 1 & 3 & 2 & 4 & 5 \\
\hline AM7: Água & 2 & $1 / 2$ & 1 & 3 & 1 & 1 & 3 & $1 / 2$ & 2 & 2 & 3 & 4 \\
\hline AM8: Biodiversidade & 1 & $1 / 3$ & $1 / 4$ & 1 & $1 / 3$ & $1 / 2$ & 1 & $1 / 4$ & $1 / 2$ & $1 / 2$ & 1 & 2 \\
\hline AM9: Emissões & 2 & 1 & 1 & 3 & 1 & 2 & 4 & $1 / 2$ & 3 & 2 & 4 & 5 \\
\hline $\begin{array}{l}\text { AM10: Efluentes e } \\
\text { Resíduos }\end{array}$ & 2 & $1 / 2$ & 1 & 2 & $1 / 2$ & 1 & 3 & $1 / 2$ & 2 & 1 & 3 & 4 \\
\hline AM11: Produtos e Serviços & $1 / 2$ & $1 / 4$ & $1 / 3$ & 1 & $1 / 4$ & $1 / 3$ & 1 & $1 / 5$ & $1 / 2$ & $1 / 2$ & $1 / 2$ & 1 \\
\hline AM12: Conformidade & 4 & 1 & 2 & 4 & 2 & 2 & 5 & 1 & 4 & 3 & 5 & 5 \\
\hline AM13: Transportes & 1 & $1 / 3$ & $1 / 2$ & 2 & $1 / 3$ & $1 / 2$ & 2 & $1 / 4$ & 1 & 1 & 2 & 3 \\
\hline AM14: Geral & 2 & $1 / 2$ & $1 / 2$ & 2 & $1 / 2$ & 1 & 2 & $1 / 3$ & 1 & 1 & 2 & 3 \\
\hline $\begin{array}{l}\text { AM15: Avaliação } \\
\text { Ambiental de } \\
\text { Fornecedores }\end{array}$ & $1 / 2$ & $1 / 4$ & $1 / 3$ & 1 & $1 / 4$ & $1 / 3$ & 2 & $1 / 5$ & $1 / 2$ & $1 / 2$ & 1 & 1 \\
\hline $\begin{array}{l}\text { AM16: Mecanismos de } \\
\text { Queixas e Reclamações } \\
\text { relacionadas a Impactos } \\
\text { Ambientais }\end{array}$ & $1 / 2$ & $1 / 5$ & $1 / 4$ & $1 / 2$ & $1 / 5$ & $1 / 4$ & 1 & $1 / 5$ & $1 / 3$ & $1 / 3$ & 1 & 1 \\
\hline
\end{tabular}

Fonte: Elaboração própria, a partir dos resultados da reunião com gestores do Grupo Algar.

Tabela 5.3 - Comparação pareada aspectos materiais da categoria 'Ambiental': visão dos stakeholders externos

\begin{tabular}{|c|c|c|c|c|c|c|c|c|c|c|c|c|}
\hline $\begin{array}{l}\text { Aspectos materiais da } \\
\text { categoria 'Ambiental' }\end{array}$ & A5 & A6 & A7 & A8 & A9 & A10 & A11 & A12 & A13 & A14 & A15 & A16 \\
\hline AM5: Materiais & 1 & $1 / 3$ & $1 / 2$ & $1 / 2$ & $1 / 3$ & $1 / 2$ & 2 & $1 / 4$ & $1 / 2$ & 1 & $1 / 2$ & $1 / 3$ \\
\hline AM6: Energia & 3 & 1 & 2 & 3 & $1 / 2$ & 2 & 3 & $1 / 2$ & 2 & 3 & 2 & 2 \\
\hline AM7: Água & 2 & $1 / 2$ & 1 & 2 & $1 / 2$ & 2 & 2 & $1 / 2$ & 2 & 2 & 2 & $1 / 2$ \\
\hline AM8: Biodiversidade & 2 & $1 / 3$ & $1 / 2$ & 1 & $1 / 3$ & $1 / 2$ & 1 & $1 / 3$ & $1 / 2$ & 2 & 1 & $1 / 3$ \\
\hline AM9: Emissões & 3 & 2 & 2 & 3 & 1 & 2 & 3 & 1 & 2 & 3 & 2 & 1 \\
\hline $\begin{array}{l}\text { AM10: Efluentes e } \\
\text { Resíduos }\end{array}$ & 2 & $1 / 2$ & $1 / 2$ & 2 & $1 / 2$ & 1 & 2 & $1 / 2$ & 2 & 2 & 2 & $1 / 2$ \\
\hline AM11: Produtos e Serviços & $1 / 2$ & $1 / 3$ & $1 / 2$ & 1 & $1 / 3$ & $1 / 2$ & 1 & $1 / 3$ & $1 / 2$ & 1 & $1 / 2$ & $1 / 3$ \\
\hline AM12: Conformidade & 4 & 2 & 2 & 3 & 1 & 2 & 3 & 1 & 2 & 3 & 2 & 2 \\
\hline AM13: Transportes & 2 & $1 / 2$ & $1 / 2$ & 2 & $1 / 2$ & $1 / 2$ & 2 & $1 / 2$ & 1 & 2 & 1 & $1 / 2$ \\
\hline AM14: Geral & 1 & $1 / 3$ & $1 / 2$ & $1 / 2$ & $1 / 3$ & $1 / 2$ & 1 & $1 / 3$ & $1 / 2$ & 1 & 2 & $1 / 3$ \\
\hline $\begin{array}{l}\text { AM15: Avaliação } \\
\text { Ambiental de } \\
\text { Fornecedores }\end{array}$ & 2 & $1 / 2$ & $1 / 2$ & 1 & $1 / 2$ & $1 / 2$ & 2 & $1 / 2$ & 1 & $1 / 2$ & 1 & $1 / 2$ \\
\hline $\begin{array}{l}\text { AM16: Mecanismos de } \\
\text { Queixas e Reclamações } \\
\text { relacionadas a Impactos } \\
\text { Ambientais }\end{array}$ & 3 & $1 / 2$ & 2 & 3 & 1 & 2 & 3 & $1 / 2$ & 2 & 3 & 2 & 1 \\
\hline
\end{tabular}

Fonte: Elaboração própria, a partir dos resultados da reunião com gestores do Grupo Algar. 
As tabelas 5.4 e 5.5 mostram as classificações dos aspectos materiais, obtidas segundo as visões dos stakeholders internos e externos, e as respectivas 'Razões de Consistência' (RC) dos julgamentos realizados em ambas as situações.

Tabela 5.4 - Grau de importância atribuída aos aspectos materiais da categoria 'Ambiental', segundo a visão dos stakeholders internos

\begin{tabular}{|c|c|c|c|}
\hline Aspecto material da categoria 'Ambiental' & $\begin{array}{l}\text { Grau de } \\
\text { importância }\end{array}$ & Ranking & RC \\
\hline AM5: Materiais & 0,053 & 80 & \multirow{12}{*}{$\begin{array}{l}0,012 \\
\text { Valor dentro do } \\
\text { padrão } \\
R C \leq=0,1\end{array}$} \\
\hline AM6: Energia & 0,157 & 29 & \\
\hline AM7: Água & 0,107 & 40 & \\
\hline AM8: Biodiversidade & 0,041 & 9응 & \\
\hline AM9: Emissões & 0,133 & 3음 & \\
\hline AM10: Efluentes e resíduos & 0,092 & 5은 & \\
\hline AM11: Produtos e serviços & 0,034 & 110 & \\
\hline AM12: Conformidade ambiental & 0,187 & 10 & \\
\hline AM13: Transportes & 0,053 & 70 & \\
\hline AM14: Geral & 0,073 & 60 & \\
\hline AM15: Avaliação ambiental de fornecedores & 0,038 & 100 & \\
\hline $\begin{array}{l}\text { AM16: Mecanismos de queixas e } \\
\text { reclamações relacionadas a Impactos } \\
\text { ambientais }\end{array}$ & 0,031 & $12 \circ$ & \\
\hline
\end{tabular}

Fonte: Elaboração própria, a partir dos resultados da reunião com gestores do Grupo Algar.

Tabela 5.5 - Grau de importância atribuída aos aspectos materiais da categoria 'Ambiental', segundo a visão dos stakeholders externos

\begin{tabular}{|c|c|c|c|}
\hline Aspecto material da categoria 'Ambiental' & $\begin{array}{l}\text { Grau de } \\
\text { importância }\end{array}$ & Ranking & RC \\
\hline AM5: Materiais & 0,040 & 11 음 & \multirow{12}{*}{$\begin{array}{l}0,029 \\
\text { Valor dentro do padrão } \\
R C \leq=0,1\end{array}$} \\
\hline AM6: Energia & 0,127 & 30 & \\
\hline AM7: Água & 0,088 & 5은 & \\
\hline AM8: Biodiversidade & 0,049 & 9음 & \\
\hline AM9: Emissões & 0,140 & 20 & \\
\hline AM10: Efluentes e resíduos & 0,079 & 60 & \\
\hline AM11: Produtos e serviços & 0,038 & $12 \div$ & \\
\hline AM12: Conformidade ambiental & 0,152 & $1 \underline{0}$ & \\
\hline AM13: Transportes & 0,066 & 70 & \\
\hline AM14: Geral & 0,045 & $10 ㅇ$ & \\
\hline AM15: Avaliação ambiental de fornecedores & 0,057 & 80 & \\
\hline $\begin{array}{l}\text { AM16: Mecanismos de queixas e } \\
\text { reclamações relacionadas a Impactos } \\
\text { ambientais }\end{array}$ & 0,119 & 40 & \\
\hline
\end{tabular}

Fonte: Elaboração própria, a partir dos resultados da reunião com gestores do Grupo Algar.

Como comentado no capítulo 4, os valores para a "Razão de Consistência" (RC) devem ser sempre menores que 0,1 (apêndice 1). Observa-se que ambos os valores RC mostrados nas tabelas 5.4 e 5.5 são menores a 0,1 , indicando que os julgamentos comparativos entre os aspectos materiais da categoria 'Ambiental' foram adequados e consistentes.

A partir dos resultados das tabelas 5.4 e 5.5 , os aspectos materiais foram plotados na matriz segundo o eixo y (visão dos stakeholders externos) e o eixo x 
(visão dos stakeholders internos). Para tal, os parâmetros adotados pelos gestores do Grupo Algar foram aqueles definidos na tabela 4.1 para esta categoria, a saber: (i) alta significância ou influência - do $1^{\circ}$ ao $3^{\circ}$ lugares no ranking, conforme resultados mostrados nas tabelas 5.4 e 5.5; (ii) média significância ou influência do $4^{\circ}$ ao $9^{\circ}$ lugares no ranking, conforme resultados mostrados nas tabelas 5.4 e 5.5; e (iii) baixa significância ou influência - do $10^{\circ}$ ao $12^{\circ}$ lugares no ranking, conforme resultados mostrados nas tabelas 5.4 e 5.5 .

Após plotagem dos 12 aspectos materiais no esquema gráfico da matriz de materialidade da categoria 'Ambiental' (figura 5.1), os gestores do Grupo Algar priorizaram na reunião de 09 de março de 2018 os aspectos posicionados no nonante superior direito, a saber: AM12 - Conformidade ambiental; AM6 - Energia; e AM9 - Emissões.

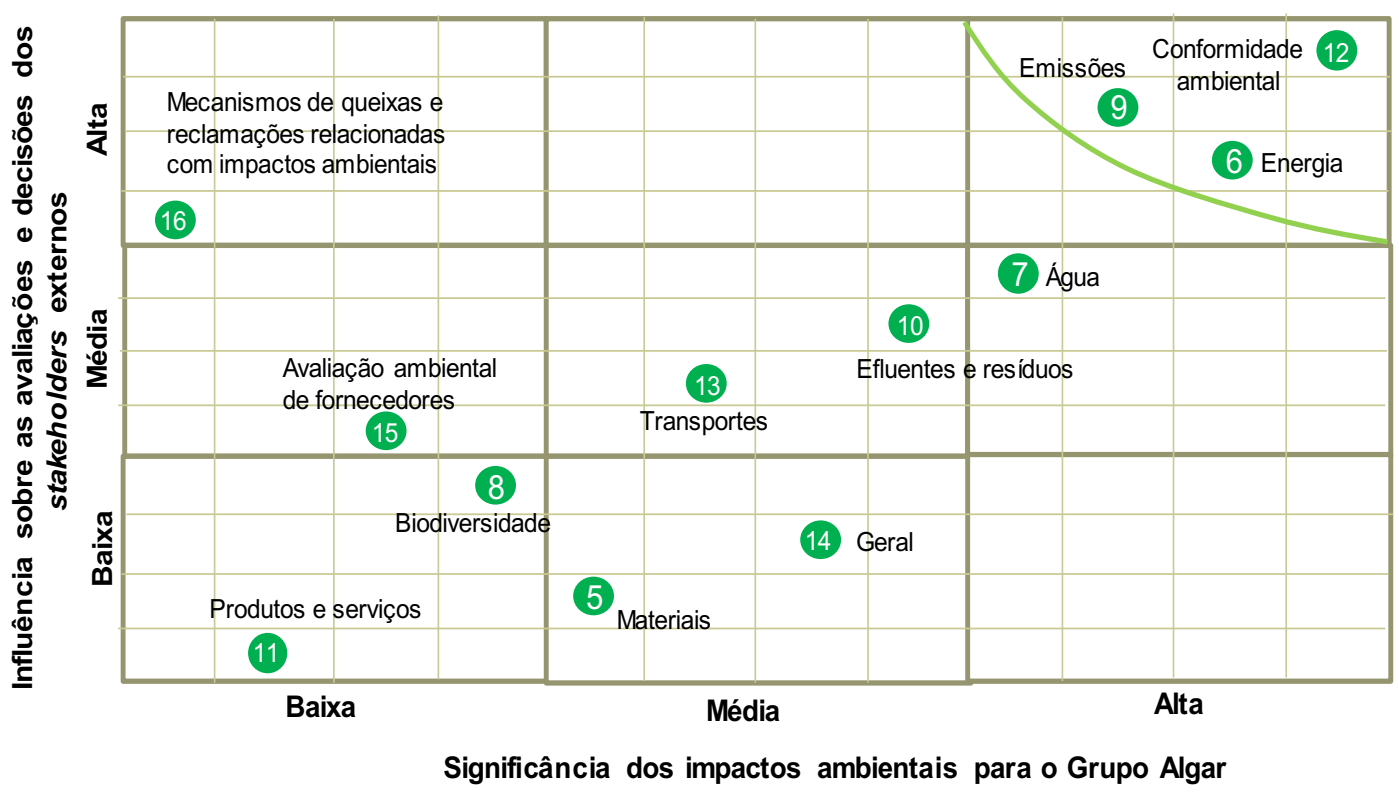

Figura 5.1 - Matriz de materialidade da categoria 'Ambiental' do Grupo Algar Fonte: Elaboração própria, a partir dos resultados da reunião com gestores do Grupo Algar.

Importante ressaltar que os resultados em relação ao eixo y foram gerados por simulação, devendo o procedimento ser replicado com os representantes dos stakeholders externos de fato, por ocasião da próxima edição do Relatório ou de revisão do Mapa Estratégico do Grupo. Os aspectos posicionados no nonante superior direito foram os priorizados na reunião de 09 de março de 2018, a saber: AM12 - Conformidade; AM6 - Energia; e AM9 - Emissões (figura 5.1).

Cabe destacar ainda que a matriz de materialidade do Grupo Algar contemplando todos os aspectos materiais definidos nas Diretrizes G4 da GRI 
deverá ser construída seguindo o mesmo procedimento descrito para a categoria 'Ambiental'. Sugere-se que os aspectos ambientais sejam representados na cor verde, como na figura 5.1, os aspectos econômicos na cor amarela e os sociais em azul, como no exemplo didático da figura 4.2.

\subsection{3.}

\section{Etapa 3: Definição da estrutura hierárquica para seleção dos indicadores de desempenho: integração da estrutura de indicadores GRI à metodologia Balanced Scorecard}

Nesta etapa, partiu-se para a definição da estrutura hierárquica para seleção dos indicadores GRI associados aos aspectos materiais da categoria 'Ambiental', que foram priorizados na etapa 2, a saber: AM12 - Conformidade; AM6 - Energia; e AM9 - Emissões.

Baseando-se nas Diretrizes G4 da GRI, destacam-se na figura 5.2 os 13 indicadores 'candidatos' associados aos aspectos priorizados na etapa anterior.
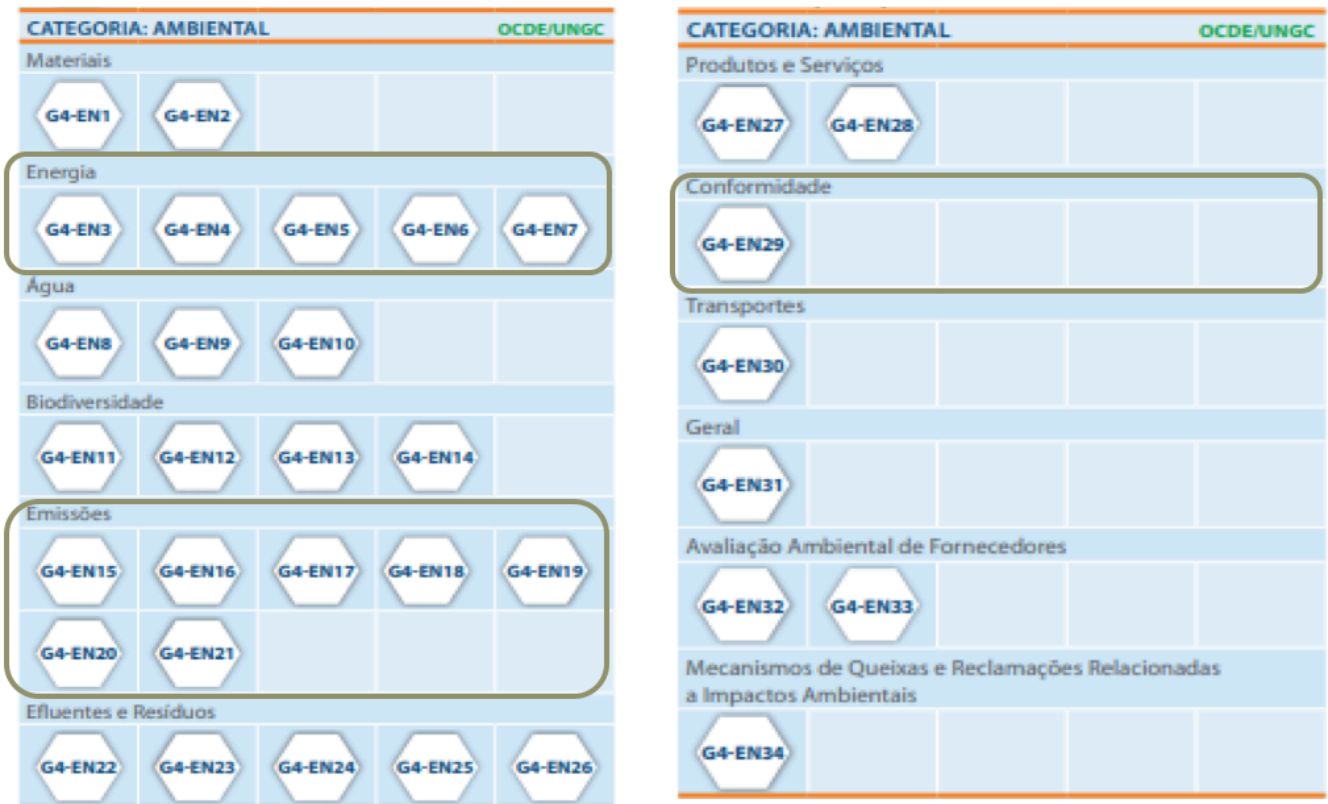

Figura 5.2 - Indicadores GRI associados aos aspectos materiais da categoria 'Ambiental' priorizados na matriz de materialidade

Fonte: Elaboração própria, com base na estrutura definida nas Diretrizes G4 da GRI (2015).

Com relação ao aspecto 'Energia', os cinco indicadores são: (i) EN3 Consumo de energia dentro da organização; (ii) EN4 - Consumo de energia fora da organização; (iii) EN5 - Intensidade energética; (iv) EN6- Redução do consumo de energia; (v) EN7 - Reduções nos requisitos de energia relacionados a produtos e serviços. 
Quanto ao aspecto 'Emissões', os sete indicadores são: (i) EN15 - Emissões diretas de gases efeito estufa - escopo 1; (ii) EN16 - Emissões indiretas de gases efeito estufa provenientes da aquisição de energia - escopo 2; (iii) EN17 - Outras emissões indiretas de gases efeito estufa - escopo 3; (iv) EN18- Intensidade de emissões de gases efeito estufa; (v) EN19 - Redução de emissões de gases efeito estufa; (vi) EN20 - Emissões de substâncias que destroem a camada de ozônio CFC; (vii) EN21 - Emissões de Nox, SOx e outras emissões.

Associado ao aspecto 'Conformidade ambiental', identificou-se um único indicador, que é o EN29 - Valor monetário de multas significativas e número total de sanções não monetárias aplicadas em decorrência da não conformidade com leis e regulamentos ambientais.

A figura 5.3 representa a estrutura hierárquica para hierarquização e seleção dos indicadores GRI 'candidatos' da categoria 'Ambiental' no contexto corporativo do Grupo Algar.

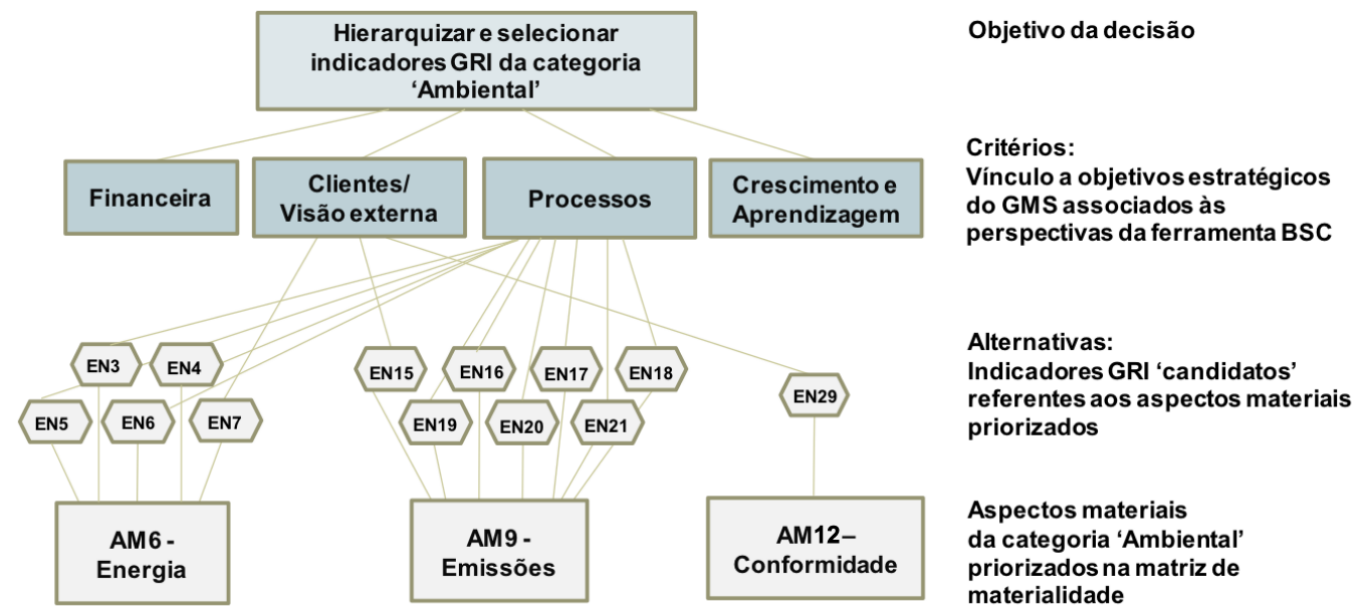

Figura 5.3 - Estrutura para hierarquização e seleção dos indicadores GRI 'candidatos' da categoria 'Ambiental' no contexto corporativo do Grupo Algar

Fonte: Elaboração própria a partir dos resultados da reunião com gestores do Grupo Algar.

A figura 5.3 mostra os indicadores EN7, EN15 e EN29 vinculados à perspectiva BSC 'Clientes/Visão Externa'. Já os indicadores EN3, EN4, EN5, EN6, EN16, EN17, EN18, EN19, EN20 e EN21 estão vinculados à perspectiva 'Processos' da ferramenta BSC. 


\subsection{4.}

\section{Etapa 4: Hierarquização e seleção de indicadores GRI da categoria 'Ambiental' com uso do método AHP-TOPSIS}

A exemplo da etapa 2, a hierarquização e seleção de indicadores GRI foi conduzida somente para a categoria 'Ambiental'. Para tal, empregou-se o método híbrido multicritério AHP-TOPSIS, como descrito no capítulo 4 e no apêndice 1.

O primeiro passo foi consultar a estrutura hierárquica das Diretrizes GRI para identificar os indicadores GRI 'candidatos' associados aos aspectos materiais da categoria 'Ambiental', que foram priorizados na etapa 2 do modelo. Os aspectos materiais priorizados foram: (i) energia; (ii) emissões; e (iii) conformidade.

A partir da identificação dos indicadores GRI 'candidatos' referentes a esses três aspectos, classificaram-se esses indicadores segundo as perspectivas da ferramenta BSC, consultando-se a proposta de classificação apresentada no quadro 4.1. Uma vez classificados os indicadores GRI 'candidatos', empregou-se o método AHP para determinar os pesos dos critérios para a categoria 'Ambiental'. Como resultado, a matriz de comparação dos critérios para seleção dos indicadores 'candidatos' da categoria 'Ambiental' é representada na tabela 5.6.

Tabela 5.6 - Matriz de comparação pareada dos critérios para seleção dos indicadores GRI 'candidatos' da categoria 'Ambiental'

\begin{tabular}{l|l|l|l|l}
\hline Perspectivas BSC (Critérios) & FI & VE & PR & AC \\
\hline FI: Financeira & $\mathbf{1}$ & 1 & $1 / 3$ & $1 / 2$ \\
\hline VE: Clientes /Visão externa & 1 & $\mathbf{1}$ & $1 / 4$ & $1 / 3$ \\
\hline PR: Processos & 3 & 4 & $\mathbf{1}$ & $1 / 2$ \\
\hline AC: Aprendizagem e crescimento & 2 & 3 & 2 & $\mathbf{1}$ \\
\hline
\end{tabular}

Fonte: Elaboração própria.

A tabela 5.7 mostra os pesos atribuídos aos critérios e a 'Razão de Consistência' (RC) dos julgamentos realizados.

Tabela 5.7 - Pesos atribuídos aos critérios para seleção dos indicadores GRI 'candidatos' da categoria 'Ambiental'

\begin{tabular}{lll}
\hline Perspectivas BSC (Critérios) & Pesos & RC \\
\hline FI: Financeira & 0,136 & \\
\cline { 1 - 2 } VE: Clientes /Visão externa & 0,115 & Valor dentro do padrão \\
\hline PR: Processos & 0,469 & $R C \leq=0,1$ \\
\hline AC: Aprendizagem e crescimento & 0,280 &
\end{tabular}

Fonte: Elaboração própria, a partir dos resultados da reunião com gestores do Grupo Algar.

Com os pesos dos critérios já definidos e indicadores GRI 'candidatos' da categoria 'Ambiental' classificados segundo as perspectivas da ferramenta BSC, construiu-se uma matriz quantitativa de avaliação de indicadores para aplicação do método TOPSIS (tabela 5.8). 
Tabela 5.8 - Matriz de avaliação quantitativa de indicadores GRI ‘candidatos' da categoria 'Ambiental' para o relatório de Sustentabilidade do Grupo Algar

\begin{tabular}{|c|c|c|c|c|c|c|c|c|c|c|c|c|c|c|c|}
\hline \multirow{3}{*}{ Indicadores GRI ‘candidatos' } & \multicolumn{3}{|c|}{$\begin{array}{l}\text { Aspectos materiais } \\
\text { priorizados }\end{array}$} & \multicolumn{4}{|c|}{ Perspectivas BSC } & \multicolumn{8}{|c|}{ Critérios para hierarquização e seleção dos indicadores* } \\
\hline & \multirow[t]{2}{*}{ AM6 } & \multirow[t]{2}{*}{ AM9 } & \multirow[t]{2}{*}{ AM12 } & \multirow[t]{2}{*}{$\mathbf{F I}$} & \multirow[t]{2}{*}{ VE } & \multirow[t]{2}{*}{ PR } & \multirow[t]{2}{*}{ AC } & \multicolumn{2}{|c|}{ FI: Financeira } & \multicolumn{2}{|c|}{$\begin{array}{l}\text { VE: Clientes/ } \\
\text { Visão externa }\end{array}$} & \multicolumn{2}{|c|}{ PR: Processos } & \multicolumn{2}{|c|}{$\begin{array}{c}\text { AC: Aprendizagem e } \\
\text { Crescimento }\end{array}$} \\
\hline & & & & & & & & $\begin{array}{c}\text { Atende } \\
* *\end{array}$ & Peso & $\begin{array}{c}\text { Atende } \\
* *\end{array}$ & Peso & $\begin{array}{c}\text { Atende } \\
* *\end{array}$ & Peso & Atende** & Peso \\
\hline $\begin{array}{l}\text { EN3 - Consumo de energia dentro do GMS e } \\
\text { das empresas do Grupo }\end{array}$ & $\mathrm{x}$ & & & & & $\mathrm{x}$ & & 1 & 0,136 & 1 & 0,115 & 9 & 0,469 & 3 & 0,280 \\
\hline $\begin{array}{l}\text { EN4 - Consumo de energia fora do GMS e } \\
\text { das empresas do Grupo }\end{array}$ & $\mathrm{x}$ & & & & & $\mathrm{x}$ & & 1 & 0,136 & 1 & 0,115 & 5 & 0,469 & 1 & 0,280 \\
\hline $\begin{array}{l}\text { EN5 - Intensidade energética no GMS e nas } \\
\text { empresas do Grupo }\end{array}$ & $x$ & & & & & $x$ & & 1 & 0,136 & 1 & 0,115 & 5 & 0,469 & 3 & 0,280 \\
\hline $\begin{array}{l}\text { EN6 - Redução do consumo de energia no } \\
\text { GMS e nas empresas do Grupo }\end{array}$ & $x$ & & & & & $x$ & & 1 & 0,136 & 1 & 0,115 & 9 & 0,469 & 5 & 0,280 \\
\hline $\begin{array}{l}\text { EN7 - Reduções nos requisitos de energia } \\
\text { relacionados a produtos e serviços }\end{array}$ & $x$ & & & & $x$ & & & 1 & 0,136 & 9 & 0,115 & 5 & 0,469 & 1 & 0,280 \\
\hline $\begin{array}{l}\text { EN15 - Emissões diretas de gases efeito } \\
\text { estufa - escopo } 1\end{array}$ & & $x$ & & & $x$ & & & 1 & 0,136 & 1 & 0,115 & 9 & 0,469 & 3 & 0,280 \\
\hline $\begin{array}{l}\text { EN16 - Emissões indiretas de gases efeito } \\
\text { estufa provenientes da aquisição de energia } \\
\text { - escopo } 2\end{array}$ & & $x$ & & & & $x$ & & 1 & 0,136 & 3 & 0,115 & 9 & 0,469 & 1 & 0,280 \\
\hline $\begin{array}{l}\text { EN17 - Outras emissões indiretas de gases } \\
\text { efeito estufa - escopo } 3\end{array}$ & & $x$ & & & & $x$ & & 1 & 0,136 & 3 & 0,115 & 5 & 0,469 & 1 & 0,280 \\
\hline $\begin{array}{l}\text { EN18- Intensidade de emissões de gases } \\
\text { efeito estufa }\end{array}$ & & $x$ & & & & $x$ & & 1 & 0,136 & 3 & 0,115 & 5 & 0,469 & 3 & 0,280 \\
\hline $\begin{array}{l}\text { EN19 - Redução de emissões de gases efeito } \\
\text { estufa }\end{array}$ & & $x$ & & & & $x$ & & 1 & 0,136 & 3 & 0,115 & 9 & 0,469 & 3 & 0,280 \\
\hline $\begin{array}{l}\text { EN20 - Emissões de substâncias que } \\
\text { destroem a camada de ozônio - CFC }\end{array}$ & & $x$ & & & & $x$ & & 1 & 0,136 & 1 & 0,115 & 3 & 0,469 & 1 & 0,280 \\
\hline $\begin{array}{l}\text { EN21 - Emissões de NOx, SOx e outras } \\
\text { emissões }\end{array}$ & & $x$ & & & & $x$ & & 1 & 0,136 & 1 & 0,115 & 9 & 0,469 & 3 & 0,280 \\
\hline $\begin{array}{l}\text { EN29 - Valor monetário de multas } \\
\text { significativas e número total de sanções não } \\
\text { monetárias aplicadas em decorrência da não } \\
\text { conformidade com leis e regulamentos } \\
\text { ambientais }\end{array}$ & & & $x$ & & $x$ & & & 3 & 0,136 & 7 & 0,115 & 5 & 0,469 & 1 & 0,280 \\
\hline
\end{tabular}

Notas: * Os critérios referem-se aos vínculos do indicador com um ou mais objetivos estratégicos do Grupo Algar na perspectiva do BSC em foco: $\mathrm{FI}$ - Financeira; VE - Clientes/Visão externa; PR - Processos; AC - Aprendizagem e crescimento.

** A escala para os julgamentos dos indicadores "candidatos" em relação ao atendimento aos critérios são: 1 - nenhum vínculo ou vínculo muito fraco com um

ou mais objetivos estratégicos da perspectiva em foco; 3 - vínculo fraco; 5 - vínculo moderado; 7 - vínculo forte; 9 - vínculo muito forte.

Legenda: AM6 - Energia; AM9 - Emissões; AM12 - Conformidade ambiental. 
O preenchimento da matriz foi conduzido pelos gestores e especialistas internos do GMS que participaram das etapas anteriores, utilizando-se a técnica TOPSIS, descrita em detalhe no apêndice 1.

Com a tabela 5.8 preenchida, procedeu-se à aplicação do método TOPSIS para hierarquização dos indicadores GRI 'candidatos' da categoria 'Ambiental' e posterior seleção para fins de elaboração do Relatório de Sustentabilidade do Grupo Algar (tabelas 5.9 a 5.12). Uma vez selecionados os indicadores GRI, os gestores deverão inclui-los no seu sistema de monitoramento e avaliação estratégica de desempenho em sustentabilidade do Grupo.

Tabela 5.9 - Soluções ideais PIS e NIS dos critérios para hierarquização e seleção dos indicadores GRI da categoria 'Ambiental'

\begin{tabular}{l|l|l}
\hline Critério & PIS & NIS \\
\hline FI - Financeira & 1,00 & 0,33 \\
\hline VE - Clientes/Visão externa & 1,00 & 0,11 \\
\hline PR - Processos & 1,00 & 0,33 \\
\hline $\begin{array}{l}\text { AC - Aprendizagem e } \\
\text { crescimento }\end{array}$ & 1,00 & 0,20 \\
\hline
\end{tabular}

Legenda: PIS - solução ideal positiva; NIS- solução ideal negativa.

Fonte: Elaboração própria.

Tabela 5.10 - Distâncias euclidianas (positivas e negativas) dos indicadores GRI da categoria 'Ambiental'

\begin{tabular}{l|l|l}
\hline Descrição & $\begin{array}{l}\mathbf{d}^{+} \\
\text {(Benefícios) }\end{array}$ & $\begin{array}{l}\mathbf{d}^{-} \\
\text {(Custos) }\end{array}$ \\
\hline $\begin{array}{l}\text { EN3 - Consumo de energia dentro do GMS e das empresas do } \\
\text { Grupo }\end{array}$ & 0,44 & 0,50 \\
\hline EN4 - Consumo de energia fora do GMS e das empresas do Grupo & 0,65 & 0,15 \\
\hline EN5 - Intensidade energética no GMS e nas empresas do Grupo & 0,54 & 0,26 \\
\hline $\begin{array}{l}\text { EN6 - Redução do consumo de energia no GMS e nas empresas do } \\
\text { Grupo }\end{array}$ & 0,39 & 0,62 \\
\hline $\begin{array}{l}\text { EN7 - Reduções nos requisitos de energia relacionados a produtos } \\
\text { e serviços }\end{array}$ & 0,58 & 0,34 \\
\hline EN15 - Emissões diretas de gases efeito estufa - escopo 1 & 0,44 & 0,50 \\
\hline $\begin{array}{l}\text { EN16 - Emissões indiretas de gases efeito estufa provenientes da } \\
\text { aquisição de energia - escopo 2 }\end{array}$ & 0,54 & 0,46 \\
\hline EN17 - Outras emissões indiretas de gases efeito estufa - escopo 3 & 0,62 & 0,17 \\
\hline EN18- Intensidade de emissões de gases efeito estufa & 0,50 & 0,27 \\
\hline EN19 - Redução de emissões de gases efeito estufa & 0,40 & 0,51 \\
\hline $\begin{array}{l}\text { EN20 - Emissões de substâncias que destroem a camada de ozônio } \\
\text { - CFC }\end{array}$ & 0,73 & 0,00 \\
\hline EN21 - Emissões de NOx, SOx e outras emissões & 0,44 & 0,50 \\
\hline $\begin{array}{l}\text { EN29 - Valor monetário de multas significativas e número total de } \\
\text { sanções não monetárias aplicadas em decorrência da não } \\
\text { conformidade com leis e regulamentos ambientais }\end{array}$ & & \\
\hline
\end{tabular}

Fonte: Elaboração própria. 
A partir das distâncias euclidianas calculadas conforme apresentado nas tabelas 5.9 e 5.10, são calculadas as proximidades relativas de cada indicador GRI da categoria 'Ambiental' em relação à PIS $(\xi)$, cujos resultados encontram-se na tabela 5.11 .

Tabela 5.11 - Proximidades relativas dos indicadores GRI 'candidatos' da categoria 'Ambiental' em relação à PIS

\begin{tabular}{l|l}
\hline Indicador & Proximidade relativa $\boldsymbol{\xi}$ \\
\hline $\begin{array}{l}\text { EN3 - Consumo de energia dentro do GMS e das empresas } \\
\text { do Grupo }\end{array}$ & 0,53 \\
\hline $\begin{array}{l}\text { EN4 - Consumo de energia fora do GMS e das empresas do } \\
\text { Grupo }\end{array}$ & 0,19 \\
\hline $\begin{array}{l}\text { EN5 - Intensidade energética no GMS e nas empresas do } \\
\text { Grupo }\end{array}$ & 0,33 \\
\hline $\begin{array}{l}\text { EN6 - Redução do consumo de energia no GMS e nas } \\
\text { empresas do Grupo }\end{array}$ & 0,62 \\
\hline $\begin{array}{l}\text { EN7 - Reduções nos requisitos de energia relacionados a } \\
\text { produtos e serviços }\end{array}$ & 0,37 \\
\hline EN15 - Emissões diretas de gases efeito estufa - escopo 1 & 0,53 \\
\hline $\begin{array}{l}\text { EN16 - Emissões indiretas de gases efeito estufa } \\
\text { provenientes da aquisição de energia - escopo 2 }\end{array}$ & 0,46 \\
\hline $\begin{array}{l}\text { EN17 - Outras emissões indiretas de gases efeito estufa - } \\
\text { escopo 3 }\end{array}$ & 0,22 \\
\hline EN18- Intensidade de emissões de gases efeito estufa & 0,35 \\
\hline EN19 - Redução de emissões de gases efeito estufa & 0,56 \\
\hline $\begin{array}{l}\text { EN20 - Emissões de substâncias que destroem a camada } \\
\text { de ozônio - CFC }\end{array}$ & 0,00 \\
\hline EN21 - Emissões de NOx, SOx e outras emissões & 0,53 \\
\hline $\begin{array}{l}\text { EN29 - Valor monetário de multas significativas e número } \\
\text { total de sanções não monetárias aplicadas em decorrência } \\
\text { da não conformidade com leis e regulamentos ambientais }\end{array}$ & 0,41 \\
\hline
\end{tabular}

Fonte: Elaboração própria

A tabela 5.12, a seguir, mostra os resultados da hierarquização dos indicadores GRI desta categoria, com o uso da técnica TOPSIS.

Cabe lembrar que este estudo empírico focalizou apenas a categoria 'Ambiental' para fins de demonstração da aplicabilidade do modelo. Assim, os gestores do Grupo Algar deverão realizar os procedimentos da etapa 4 para todas as categorias/subcategorias das Diretrizes G4 da GRI. Depois de gerados os resultados, como os apresentados na tabela 5.12, eles deverão consolidar a relação dos indicadores GRI de todas as categorias/subcategorias para elaboração do Relatório de Sustentabilidade e inclusão na sistemática de monitoramento e avaliação estratégica do desempenho em sustentabilidade do Grupo. 
Tabela 5.12 - Hierarquização dos indicadores GRI 'candidatos' da categoria 'Ambiental'

\begin{tabular}{|c|c|c|}
\hline Posição & Indicador & $\begin{array}{l}\text { Proximidade } \\
\quad \text { relativa } \xi\end{array}$ \\
\hline 10 & $\begin{array}{l}\text { EN6 - Redução do consumo de energia no GMS e nas empresas do } \\
\text { Grupo }\end{array}$ & 0,62 \\
\hline 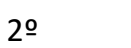 & EN19 - Redução de emissões de gases efeito estufa & 0,56 \\
\hline 3은 & EN3 - Consumo de energia dentro do GMS e das empresas do Grupo & 0,53 \\
\hline 3은 & EN15 - Emissões diretas de gases efeito estufa - escopo 1 & 0,53 \\
\hline 3은 & EN21 - Emissões de NOx, SOx e outras emissões & 0,53 \\
\hline 40 & $\begin{array}{l}\text { EN16 - Emissões indiretas de gases efeito estufa provenientes da } \\
\text { aquisição de energia - escopo } 2\end{array}$ & 0,46 \\
\hline 50 & $\begin{array}{l}\text { EN29 - Valor monetário de multas significativas e número total de } \\
\text { sanções não monetárias aplicadas em decorrência da não } \\
\text { conformidade com leis e regulamentos ambientais }\end{array}$ & 0,41 \\
\hline 6은 & $\begin{array}{l}\text { EN7 - Reduções nos requisitos de energia relacionados a produtos e } \\
\text { serviços }\end{array}$ & 0,37 \\
\hline 7으 & EN18 - Intensidade de emissões de gases efeito estufa & 0,35 \\
\hline 80 & EN5 - Intensidade energética no GMS e nas empresas do Grupo & 0,33 \\
\hline 9o & EN17 - Outras emissões indiretas de gases efeito estufa - escopo 3 & 0,22 \\
\hline 9o & EN4 - Consumo de energia fora do GMS e das empresas do Grupo & 0,19 \\
\hline 10 은 & $\begin{array}{l}\text { EN20 - Emissões de substâncias que destroem a camada de ozônio - } \\
\text { CFC }\end{array}$ & 0 \\
\hline
\end{tabular}

Fonte: Elaboração própria.

Deve-se ressaltar ainda que durante as reuniões do período de 07 a 09 de março de 2018 com os gestores do Grupo Algar, constatou-se a necessidade de revisar o processo de planejamento estratégico do Grupo para criação de um BSC sustentável, como abordado no capitulo 2 e exemplificado na reunião com os seguintes casos de grupos multissetoriais: (i) General Electric (GE) e (ii) Siemens.

Desse modo, simulou-se durante a última reunião esta revisão, formulandose um novo objetivo estratégico referente a práticas de sustentabilidade ambiental na perspectiva BSC 'Processos' e um segundo objetivo referente à responsabilidade por produtos e serviços na perspectiva 'Clientes/Visão Externa'. Acredita-se que na prática a própria aplicação no contexto corporativo do modelo em suas cinco etapas, cobrindo todas as categorias e subcategorias, poderá contribuir de forma significativa para integrar de forma sistêmica e sinérgica os processos de elaboração do Relatório de Sustentabilidade e do planejamento estratégico corporativo, com utilização da ferramenta BSC sustentável, como abordado no capítulo 2. 


\subsection{5. \\ Etapa 5: Elaboração das identidades dos indicadores selecionados e respectivas métricas}

Nesta etapa, adotou-se o metamodelo apresentado no capítulo 4 para especificar as identidades do indicador EN6 (redução do consumo de energia no Grupo Algar e nas empresas do Grupo), conforme apresentado no quadro 5.1.

Quadro 5.1 - Identidade do indicador EN6 - Redução do consumo de energia no Grupo Algar e nas empresas do Grupo

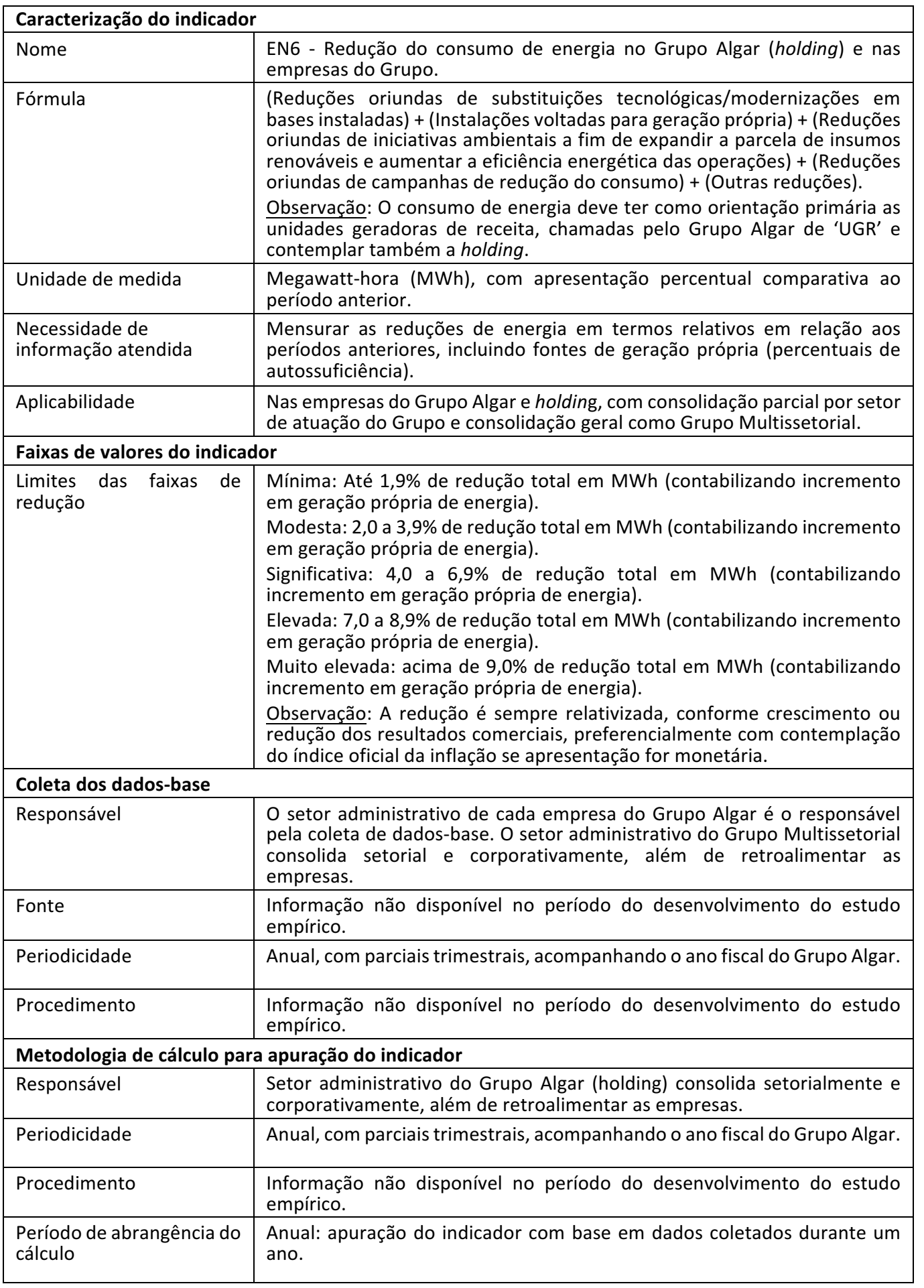




\begin{tabular}{|c|c|}
\hline \multicolumn{2}{|l|}{ Análise pós-cálculo } \\
\hline Responsável & $\begin{array}{l}\text { Comitês da Sustentabilidade de cada empresa, sob a coordenação do } \\
\text { Instituto Algar, analisam as medições apuradas e sugerem ações para } \\
\text { tratamento dos desvios e implantação de novos programas relacionados ao } \\
\text { aspecto material energia. }\end{array}$ \\
\hline Procedimento & $\begin{array}{l}\text { a) Dado apurado deve ser comparado com o mesmo relativo ao período } \\
\text { anterior (exemplos: ano de 2017/ano de 2016; } 1^{\circ} \text {. semestre de } \\
2018 / 1^{\circ} \text {. semestre de 2017) - em todos os níveis de medição } \\
\text { (empresas, setores e corporativo multissetorial); } \\
\text { b) Medição deve ser associada aos programas empresariais vigentes } \\
\text { (modernizações de bases instaladas, substituiçães tecnológicas de } \\
\text { menores dimensões e/ou consumos de energia, campanhas de } \\
\text { consumo consciente e/ou iniciativas de menor impactos ambientais, } \\
\text { entre outros a especificar); } \\
\text { c) Consolidação parcial por setores de atuação das empresas do Grupo } \\
\text { Algar visando comparações de contribuição por empresas e por } \\
\text { setores; } \\
\text { d) Consolidação geral corporativa multissetorial, incluindo a indicação e } \\
\text { significado das faixas de valores possíveis de medição. }\end{array}$ \\
\hline $\begin{array}{l}\text { Possíveis causas de } \\
\text { desvios }\end{array}$ & Indicação de possíveis causas de desvios no processo de medição. \\
\hline Possíveis ações gerenciais & $\begin{array}{l}\text { Sugestões de possíveis ações gerenciais para tratamento dos desvios no } \\
\text { processo de medição. }\end{array}$ \\
\hline \multicolumn{2}{|c|}{ Disponibilização dos resultados para tomada de decisão } \\
\hline Divulgação & $\begin{array}{l}\text { Relatório Anual de Sustentabilidade (stakeholders externos). } \\
\text { Relatórios de gerenciamento estratégico BSC (stakeholders internos). }\end{array}$ \\
\hline \multicolumn{2}{|l|}{ Segurança da informação } \\
\hline Local de armazenamento & $\begin{array}{l}\text { Informação não disponível no período do desenvolvimento do estudo } \\
\text { empírico. }\end{array}$ \\
\hline Nível de acesso & $\begin{array}{l}\text { Não foi possível obter informação sobre os órgãos e setores que devem } \\
\text { possuir acesso aos resultados e às análises da medição, durante o período } \\
\text { do desenvolvimento do estudo empírico. }\end{array}$ \\
\hline Integridade dos dados & $\begin{array}{l}\text { Não foi possível obter informação sobre procedimentos adicionais para } \\
\text { garantia da integridade dos dados coletados, apurados e analisados, } \\
\text { durante o período do desenvolvimento do estudo empírico. }\end{array}$ \\
\hline
\end{tabular}

A título de ilustração, apresentam-se os resultados consolidados do Grupo Algar para o indicador EN6 no ano de 2017, confome figura 5.4.

\section{Eletricidade Comprada por Associado (MWh/associado)'}

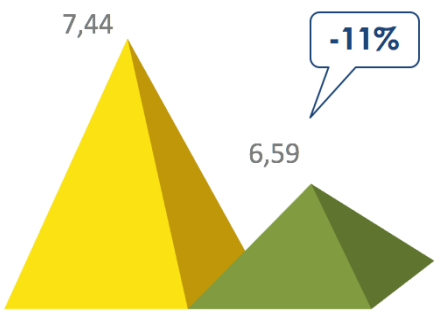

Emissões de Escopo 1 por Associado (tCO2e/associado) ${ }^{1}$
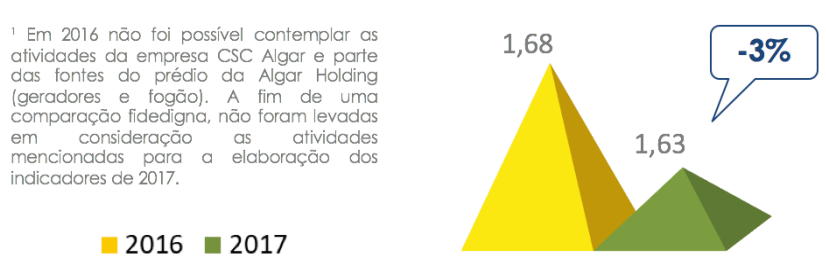

Variação na Geração de Energia Fotovoltaica 2016 - 2017

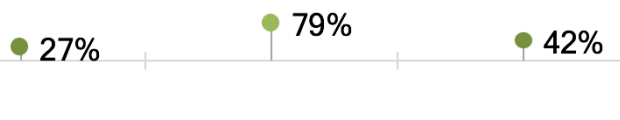

$-100 \%$

Alsol

Tech

Telecom

Grupo

Figura 5.4 - Apresentação dos resultados consolidados para EN6 (Energia) - Grupo Algar Fonte: Inventário de Emissões de GEE de 2017 do Grupo Algar (março/2018). 
A figura 5.4 apresenta como resultado apurado em 2017 frente ao ano de 2016 a redução de $11 \%$ (onze por cento) na eletricidade comprada por associado (funcionário). Apresenta também, a redução de 3\% (três por cento) das emissões de escopo 1 por associado (funcionário), e as variações da geração de energia fotovoltaica para as empresas geradoras do grupo e para o Grupo Algar.

O inventário de amissões de GEE de 2017 do Grupo Algar relata outros indicadores relevantes com destaque para: (i) aumento de 6\% (seis por cento) das emissões escopo 2 em tCO2e; (ii) aumento de 14\% (quatorze por cento) do fator de emissão em tCO2/MWh; (iii) aumento de 3\% (três por cento) da eletricidade comprada por receita bruta em $\mathrm{MWh} / \mathrm{R} \$$ milhões; (iv) aumento de $15 \%$ das emissões de escopo 1 por receita bruta em tCO2e/R\$milhões; (v) emissões absolutas e percentuais de participação por empresa e holding (aumento ou reduções) com detalhamento das razões para os resultados; (vi) emissões percentuais por fonte de emissões; (vii) fontes estacionárias e móveis por empresas e holding (aumento ou reduções absolutas e percentuais); (viii) eletricidade comprada em MWh por empresa e holding com comparativo em relação ao período anterior (2017-2016), com apresentação das variações absolutas e percentuais (aumentos ou reduções).

O indicador principal do consumo de energia apresenta um resultado de $-5 \%$ (redução de cinco por cento) em 2017 comparativamente ao período anterior (ano de 2016), o que permite a classificação desse resultado na faixa de 'significativa' conforme modelo apresentado no quadro 5.1.

\section{5.}

\section{Conclusões do estudo empírico}

Pelos resultados apresentados neste capítulo, pode-se demonstrar a aplicabilidade do modelo conceitual para o monitoramento e avaliação de desempenho em sustentabilidade de grupos multissetoriais, mediante o estudo empírico desenvolvido no contexto corporativo do Grupo Algar, focalizando a categoria 'Ambiental' das Diretrizes G4 da Global Reporting Initiative.

Os gestores e especialistas do Grupo, que participaram deste estudo empírico, consideraram o formato e os conteúdos das matrizes adequados para aplicação posterior, com destaque para a matriz de seleção de stakeholders externos e a matriz de avaliação quantitativa de indicadores GRI 'candidatos' da categoria abordada no estudo. 
Buscou-se contribuir para o refinamento e melhoria contínua dos procedimentos adotados atualmente pelo Grupo para priorização dos aspectos materiais e construção da matriz de materiailidade, onde aplicou-se com sucesso o método multicritério de apoio à decisão AHP. Os aspectos materiais da categoria 'Ambiental' que foram priorizados com apoio deste método foram 'Energia', 'Emissões' e 'Conformidade ambiental'.

Para a etapa de hierarquização e seleção dos indicadores GRI da categoria 'Ambiental', empregou-se também com sucesso o método híbrido multicritério AHP-TOPSIS. O método AHP foi usado para a definição dos pesos dos critérios, definidos como vínculos dos indicadores a um ou mais objetivos estratégicos de cada perspectiva do Balanced Scorecard. A análise dos vínculos dos indicadores GRI 'candidatos' com um ou mais objetivos estratégicos do Grupo Algar revelou a inexistência no Mapa Estratégico BSC do Grupo de objetivos estratégicos que expressassem os esforços e iniciativas que vem sendo realizadas pelo Grupo.

Com esse alinhamento, reconheceu-se a necessidade de se definir uma estratégia deliberada de sustentabilidade, cujos objetivos estratégicos sejam incluídos no Mapa Estratégico do Grupo, em todas as quatro perspectivas. Com isso, os indicadores GRI reportados no Relatório de Sustentabilidade do Grupo poderão ser de fato instrumentos de monitoramento e avaliação estratégica de desempenho em sustentabilidade do Grupo, indo além da função de comunicação institucional com seus stakeholders. Os exemplos dos GMSs General Eletric e Siemens, apresentados aos gestores do Grupo Algar durante as reuniões de aplicação do modelo e detalhados nas considerações finais do capítulo 2, reforçam a importância real dessa aplicação e o impacto positivo tanto para os gestores quanto para todos que estão direta e indiretamente envolvidos nos processos relacionados à avaliação do desempenho em sustentabilidade.

Neste contexto de aplicação, destacam-se os seguintes diferenciais do modelo proposto nesta pesquisa em relação aos procedimentos adotados atualmente pelo Grupo Algar:

- O método híbrido AHP-TOPSIS levou em consideração a complexidade e a subjetividade, que são características intrínsecas ao processo de mensuração e avaliação de desempenho em sustentabilidade de grupos multissetoriais;

- O método AHP permitiu estabelecer menos subjetivamente os pesos dos critérios baseados nas perspectivas da ferramenta BSC, uma vez que, ao 
final das comparações pareadas, foi calculada a razão de consistência dos julgamentos realizados pelos gestores do Grupo. Caso a razão de consistência tivesse dado superior a 0,1 , os gestores teriam a oportunidade de rever seus julgamentos;

- A proposição de se alinhar os indicadores GRI aos objetivos estratégicos do Grupo (por perspectiva da ferramenta BSC) foi percebida pelos gestores que participaram do estudo empírico como um grande diferencial do modelo em relação às práticas atualmente adotadas pelo Grupo.

- A hierarquização dos indicadores GRI da categoria 'Ambiental' pela técnica TOPSIS mostrou-se efetiva e muito simples em termos de sua implementação em planilha. Constitui de fato um refinamento metodológico em relação à média ponderada proposta em outros referenciais e guias metodológicos (Brasil, 2010, por exemplo). Permitiu avaliar a importância de cada indicador GRI 'candidato' pela sua similaridade com a solução ideal. Ou seja, os melhores indicadores são aqueles mais próximos da solução ideal positiva e mais distantes da solução ideal negativa (tabelas 5.10 e 5.11).

Finalmente, em resposta à questão principal deste estudo empírico, a aplicação do modelo conceitual no contexto corporativo do Grupo Algar permitiu selecionar com objetividade os indicadores GRI da categoria 'Ambiental', trazendo para o Grupo um novo ferramental de gerenciamento estratégico da sustentabilidade corporativa. Houve o reconhecimento dos benefícios potenciais da aplicação futura do modelo em sua totalidade (todas as categorias e todas as empresas do Grupo), visto como uma sistemática de gerenciamento estratégico da sustentabilidade corporativa, integrada à ferramenta Balanced Scorecard já empregada pelo Grupo. 


\section{6 \\ Conclusões}

A presente pesquisa contribuiu para o avanço do conhecimento sobre o tema avaliação de desempenho de grupos multissetoriais, na perspectiva da sustentabilidade corporativa. Nesse sentido, um modelo conceitual de monitoramento e avaliação de desempenho em sustentabilidade foi desenvolvido para esses grupos, partindo-se do pressuposto que sua adoção na prática poderá contribuir para que alcancem patamares superiores de avaliação do desempenho em sustentabilidade. Os resultados obtidos ao longo da pesquisa aqui relatada permitiram que o objetivo geral da dissertação fosse alcançado. Foi possível demonstrar sua aplicabilidade mediante o desenvolvimento de um estudo empírico no Grupo Algar, para fins de replicação futura em outros GMS congêneres.

As abordagens conceituais e metodológicas discutidas nos capítulos 2 e 3 fundamentaram o desenvolvimento e aplicação do referido modelo, contribuindo de forma significativa para que os objetivos específicos da dissertação fossem alcançados.

Pelos aspectos descritos e resultados gerados na fase aplicada da pesquisa, considera-se que eles propiciarão aos gestores de grupos multissetoriais, bem como às diversas partes interessadas na sustentabilidade corporativa desses grupos, um ferramental adequado e inovador para o gerenciamento estratégico na perspectiva da sustentabilidade, visando definição de metas de curto, médio e longo prazo orientadas para patamares superiores de desempenho. Quando aplicados pelos GMS em toda sua abrangência, poderá ser considerada uma inovação organizacional.

Com relação ao primeiro objetivo específico - "discutir a contribuição dos referenciais normativos, diretrizes e guias para elaboração de relatórios de sustentabilidade aplicáveis a grupos multissetoriais", conclui-se que as Diretrizes G4 publicadas pela Global Reporting Initiative mostraram-se as mais adequadas por incluir em seu escopo elementos e critérios associados diretamente à abordagem de sustentabilidade corporativa, contemplando suas três dimensões e o 
envolvimento dos stakeholders na escolha dos temas e indicadores que deverão ser objeto da avaliação de desempenho por parte do grupo em dois níveis - corporativo multissetorial e setorial (por unidade de negócio).

No que tange ao segundo objetivo "identificar as principais abordagens metodológicas de avaliação de desempenho em sustentabilidade, evidenciando-se a lacuna referente a grupos multissetoriais", constatou-se de fato a inexistência de modelos desenvolvidos para GMSs, até mesmo de suplementos orientativos divulgados pela GRI, com base na revisão bibliográfica e na análise documental sobre o tema, cobrindo o período de 1988 a 2018.

O terceiro objetivo - "propor um modelo de monitoramento e avaliação de desempenho em sustentabilidade para grupos multissetoriais, com uso de métodos multicritério de apoio à decisão e que sirva de ferramenta de gerenciamento estratégico da sustentabilidade, além da função de comunicação anual para os diversos stakeholders", foi atingido ao se apresentar para os GMSs um ferramental capaz de identificar e envolver objetivamente os stakeholders desde o início do processo da construção da matriz de materialidade. Outro ponto fundamental apresentado é a integração da estrutura GRI ao BSC, por meio respectivamente dos indicadores e perspectivas.

Em relação ao quarto objetivo específico "demonstrar empiricamente a aplicabilidade do modelo proposto no contexto de um grupo multissetorial brasileiro - Grupo Algar”. A conclusão é que é plausível é que um GMS como o Grupo Algar possa utilizar diretamente da metodologia apresentada para melhoria do processo de elaboração e publicação do Relatório da Sustentabilidade Corporativa, pois há ganhos explícitos em todas as etapas do processo: (i) seleção e envolvimento dos stakeholders; (ii) construção de matrizes por categoria/subcategoria com consolidação em uma matriz integrada tendo a certeza que todas as categorias/subcategorias foram apreciadas sob lentes adequadas; (iii) análise criteriosa dos indicadores de desempenho e a conscientização interna das respectivas importâncias e impactos dos mesmos.

Os resultados do estudo empírico permitiram comprovar que faz sentido a integração do processo relacionado à elaboração do Relatório da Sustentabilidade ao processo de planejamento estratégico do GMS. Empiricamente, verificou-se que os representantes internos tanto do GMS quanto das empresas setoriais do mesmo sentiram-se mais envolvidos em termos qualitativos, perceberam o impacto relacional que um minucioso trabalho de coleta de dados pode ter nas principais 
decisões estratégicas do GMS, enfim, compreenderam que o Relatório da Sustentabilidade Corporativa é uma peça fundamental para o desenvolvimento contínuo e sustentável do GMS. Assim, o quarto objetivo específico da pesquisa também foi alcançado.

Para trabalhos futuros de desdobramento da pesquisa e aprofundamento dos resultados, propõem-se:

- Aplicação da lógica fuzzy, combinada com métodos multicritério de apoio à decisão, para redução das incertezas dos julgamentos realizados nas etapas de priorização dos aspectos materiais e dos indicadores GRI;

- Integração dos processos de elaboração dos Relatórios da Sustentabilidade do GMS e das empresas setoriais do mesmo.

- Avaliação de impactos oriundos do planejamento estratégico na avaliação do desempenho em sustentabilidade do GMS, e vice-versa, com retroalimentações constantes para que a alta administração e os representantes da sustentabilidade possam realizar constantes ajustes em seus respectivos processos.

- Realização de estudos de casos múltiplos abrangendo diversos GMSs atuando em diferentes setores, para fins comparativos dos resultados do estudo empírico, focalizando o Grupo Algar.

Finalmente, acredita-se que os resultados desta pesquisa poderão ser replicados em processos de avaliação de desempenho em sustentabilidade de outros grupos multissetoriais no Brasil e no exterior. No âmbito da GRI, poderão contribuir para a elaboração de um suplemento orientativo para grupos multissetoriais, i.e., G4 Multisectoral Disclosures. 


\section{Referências bibliográficas}

ABNT. ISO. Norma ABNT NBR ISO 9004:2010. Gestão para o sucesso sustentado de uma organização - uma abordagem da gestão da qualidade. São Paulo: ABNT.ISO, 2010.

ARORA, V. A Balanced scorecard framework for measuring sustainability performance of business organizations. 2015. 127p. Thesis (Master of Applied Science - Quality Systems Engineering). Concordia University. Institute for Information Systems Engineering (CIISE). Montreal, Quebec, Canada, 2015.

BELlantUONO, N.; PONTRANDOLFO, P.; SCOZZI B. Capturing the stakeholders' view in sustainability reporting: A novel approach. Sustainability, v.8, n.4, p.379 - 391, 2016.

VAN BELLEN, H. M. V. Indicadores de sustentabilidade: uma análise comparativa. 1. ed. Rio de Janeiro: Editora FGV, 2005.

VAN BELLEN, H.M.V. Indicadores de sustentabilidade: uma análise comparativa. 2002. Tese (Doutorado em Engenharia de Produção). Curso de Pósgraduação em Engenharia de Produção, Universidade Federal de Santa Catarina, 2002 .

BIEKER, T. Sustainability management with the Balanced Scorecard. In: International Summer Academy on Technology Studies - Corporate Sustainability, v. 51, p.121-146, 2005.

BIEKER, T.; GMINDER, C-U. Towards a Sustainability Balanced Scorecard. In: Proceedings of the 2001 Business Strategy and the Environment Conference. Leeds, U.K., 2001.

BM\&FBovespa. Índice Carbono Eficiente ICO2. Disponível em: $<\mathrm{http}$ ://www.bmfbovespa.com.br/pt_br/produtos/indices/indices-desustentabilidade/indice-carbono-eficiente-ico2.htm>. Acesso em: 10 abr. 2018.

BRIGNALL, T.J.S. The unbalanced scorecard: a social and environmental critique. In: Neely A., Walters A. and Austin R. (Eds.). Performance measurement and management: research and action. Boston: Performance Measurement Association, 2002.

BRUCKER, K. DE.; MACHARIS, C.; VERBEKE, A. Multi-criteria analysis and the resolution of sustainable development dilemmas: A stakeholder management approach. European Journal of Operational Research, v. 224, p. 122-131, 2013.

CALABRESE, A.; COSTA, R.; LEVIALDI, N.; MENICHINI T. A fuzzy analytic hierarchy process method to support materiality assessment in sustainability reporting. Journal of Cleaner Production 121, p. 248-264, 2016. 
CALABRESE, A.; COSTA, R.; MENICHINI, T.; ROSATI, F. Does corporate social responsibility hit the mark? a stakeholder oriented methodology for CSR assessment. Knowledge and Process Management, v.20, n.2. p. 77-89, 2013.

CARPEJANI, P.; PINHEIRO DE LIMA, E.; MACHADO, C. G. O que é materialidade na GRI G4? Uma discussão e agenda para pesquisas futuras. In: The 6th International Workshop on Advances in Cleaner Production. São Paulo, 24 -26 de maio de 2017.

CARROLL, A. B. The pyramid of corporate social responsibility: toward the moral management of organizational stakeholders. Business Horizons, v.34, n.4, p.3948, 1991.

CARROLL, A.B. Corporate social responsibility. Evolution of a definitional construct. Business and Society, v.38, n.3, p.268-295, 1999.

CARROLL, A. B.; SHABANA, K. M. The business case for corporate social responsibility: a review of concepts, research and practice. International Journal of Management Reviews, v.275, p. 85-106, 2010.

CHENG, C.Y.; FET, A.M.; HOLMEN, E. Using a hexagonal balanced scorecard approach to integrate corporate sustainability into strategy. In: Proceedings of the 16th International Sustainable Development Research Conference 2010, Track: Implementing Integrated Corporate Sustainability Frameworks; Hong Kong: June, 2010 .

CONFEDERAÇÃO NACIONAL DA INDÚSTRIA. CNI. Estratégias corporativas de baixo carbono. Gestão de riscos e oportunidades. Guia de referência. 2011. Disponível em: <http://admin.cni.org.br>. Acesso em: 10 abr. 2018 .

COSTA, R.; MENICHINI, T. A multidimensional approach for CSR assessment: The importance of the stakeholder perception. Expert Systems with Applications, v. 40, p. 150-161, 2013.

COSTA, H. G. Auxílio multicritério à decisão: método AHP. Rio de Janeiro: Abepro. 2006.

COUTO, C. G. Sociedades controladoras: holding. Brasília: Fundação Getúlio Vargas, 2012.

DAHLSRUD, A. How corporate social responsibility is defined: an analysis of 37 definitions. Corporate Social Responsibility and Environmental Management, v.15, n.1, p. 1-5. 2008.

DELAI, I., TAKAHASHI, S. Uma proposta de modelo de referência para mensuração da sustentabilidade corporativa. RGSA - Revista de Gestão Social e Ambiental, v.2, n.1, p.19-40, 2008. 
DUNPHY, D.C.; GRIFFITHS, A.; BENN, S. Organizational change for corporate sustainability: a guide for leaders and change agents of the future. 2nd ed. London, U.K.; New York, U.S.A.: Routledge, 2007.

DYLLICK, T.; HOCKERTS, K. Beyond the business case for corporate sustainability. Business Strategy and the Environment, v. 11, n. 2, p. 130-141, 2002.

ELKINGTON, J. Cannibals with forks: Triple bottom line of 21st century business. London: Capstone Publishing Ltd, 1998.

EPSTEIN, M. J. Making sustainability work: best practices in managing and measuring social and environmental impacts. Sheffield: Greenleaf, 2008.

EPSTEIN, M.J.; ROY, M-J. Improving sustainability performance: specifying, implementing and measuring key principles. Journal of General Management, v.29, n1, p.15-31, 2003.

FIGGE, F.; HAHN, T.; SCHALTEGGER, S.; WAGNER, M. The sustainability balanced scorecard - linking sustainability management to business strategy. Business Strategy and the Environment, v.11, p.269-284, 2002.

FIKSEL, J.; MCDANIEL, J.; MENDENHALL, C. Measuring progress towards sustainability: principles, process, and best practices. Columbus, Ohio: Battelle Memorial Institute, Life Cycle Management Group, 1999.

FREEMAN, R.E. Strategic management: a stakeholder approach. Marshfield, MA: Pittman, 1984.

FREEMAN, R.E.; HARRISON, J.S.; WICKS, A.C. Managing for stakeholder: survival, reputation, and success. New Haven: Yale University Press, 2007.

GALVÃO, H.M.; KRUGLIANSKAS, I. O desempenho das práticas de gestão para a sustentabilidade: modelo de avaliação socioambiental aplicado na indústria. In: 2013 Simpósio de Excelência em Gestão e Tecnologia. Resende, RJ, 31 de outubro a 01 de novembro, 2013.

GLOBAL REPORTING INITIATIVE. Diretrizes para relato de sustentabilidade. Princípios para relato e conteúdos padrão. Global Reporting Initiative (GRI), 2a. ed. São Paulo: GRI, 2015.

GMINDER, C.U.; BIEKER, T. Managing corporate social responsibility by using the "sustainability-balanced scorecard". In: Proceedings of the 10th International Conference of the Greening of Industry Network, Göteborg, Sweden, 23-26 June 2002.

HART, S. L.; MILSTEN, M. B. Criando valor sustentável. Revista de Administração de Empresas - RAE, São Paulo, v. 3, n. 7, p. 65-79, maio/jun. 2004. 
HEDSTROM, G.; POLTORZYCKI, S.; STROH, P. Sustainable development: the next generation., in Sustainable Development: How Real, How Soon, and Who's Doing What? Prism, v. 4, p. 5-19, 1998.

HSU, C.; LEE, W; CHAO, W. Materiality analysis model in sustainability reporting: a case study at Lite-On Technology Corporation. Journal of Cleaner Production, v. 57, p.142-151, 2013.

HUBBARD, G. Measuring organizational performance: Beyond the triple bottom line. Business Strategy and the Environment, v.18, n.3, p. 177-191, 2009.

HUBBARD, G. Sustainable organization performance: towards a practical measurement system. Monash Business Review, v.2, n.3, p. 25-29, 2006.

HWANG, C. L. YOON, K. Multiple attribute decision making: methods and applications, New York: Springer-Verlag. 1981.

INSTITUTO ETHOS de Empresas e Responsabilidade Social. Indicadores Ethos para negócios sustentáveis e responsáveis. Disponível em: < https://www3.ethos.org.br/conteudo/indicadores/\#.WtPLu4jwbIU $>$. Acesso em:10 abr. 2018.

INSTITUTO ETHOS de Empresas e Responsabilidade Social. Práticas empresariais de responsabilidade social: relações entre os princípios do Global Compact e os indicadores Ethos de responsabilidade social. [Carmen Weingrill, coordenadora]. São Paulo: Instituto Ethos, 2003. Disponível em: $<$ http://www.ethos.org.br/sistemas/ifc/>. Acesso em:10 abr. 2018.

KALENDERA, Z. T.; VAYVAY, Ö. The fifth pillar of the balanced scorecard: sustainability. Procedia - Social and Behavioral Sciences, v. 235, n. 2016, p.7683, 2016.

KAPLAN, R. S.; NORTON, D. P. The Balanced Scorecard - measures that drive performance. Harvard Business Review, v. 70, n. 1, p. 71-79, 1992.

KAPLAN, R, S.; NORTON, D. P. Estratégia em ação - Balanced Scorecard. Tradução de Luiz Euclydes Trindade Frazão Filho. Rio de Janeiro: Campus, 1997.

KAPLAN R.S.; NORTON D.P. Organização orientada para a estratégia. Rio de Janeiro: Editora Campus, 2000.

KAPLAN R.S.; NORTON D.P. Mapas Estratégicos. Rio de Janeiro: Editora Campus, 2003.

MCKINSEY. The business of sustainability: McKinsey Global Survey results Disponível em: <https://www.mckinsey.com/business-functions/sustainabilityand-resource-productivity/our-insights/the-business-of-sustainability-mckinseyglobal-survey-results>. Acesso em: 10 abr. 2018.

MENECHINI, T.; ROSATI, F. A fuzzy approach to improve CSR reporting: an application to the Global Reporting Initiative indicators. Procedia - Social and Behavioral Sciences, v. 109, p. 355-359, 2014. 
MITCHELL, R.; AGLE, B.; WOOD, D. Toward a theory of stakeholder identification and salience: defining the principle of who and what really counts, Academy of Management Review, v.22, n.4, p. 853-858, 1997.

NEELY, A.; GREGORY, M.; PLATTS, K. Performance measurement system design - a literature review and research agenda. International Journal of Operations \& Production Management, Bradford, v. 15, n. 4, p. 80-116, 1995.

NEELY, A. The evolution of performance measurement research - developments in the last decade and a research agenda for the next. International Journal of Operations \& Production Management, v.25, n.12, p.1264-1277, 2005.

NELLING, E.; WEBB, E. Corporate social responsibility and financial performance: the "virtuous circle" revisited". Review of Quantitative Finance and Accounting, v.32, n.2, p.197-209, 2009.

NIKOLAOU, I.E.; TSALIS, T.A. Development of a sustainable balanced scorecard framework. Ecological Indicators, v.34, p.76-86, 2013.

PANAYIOTOU, N.A.; ARAVOSSIS, K.G.; MOSCHOU, P. A new methodology approach for measuring corporate social responsibility performance. Water Air Soil Pollut: Focus, v.9, n.1-2, p. 129-138, 2009.

PORRITT, J. External Comment on Sustainability Initiatives. 2001. Disponível em: $<$ http://www.unilever.com/environmentsociety/sustainabilityinitiatives/agriculture >. Acesso em: 10 abr. 2018.

PORTER, M. E.; KRAMER, M.R. Strategy and society: the link between competitive advantage and corporate social responsibility. Harvard Business Review, December 2006, p. 1-14. 2006.

PROGRAMA BRASILEIRO GHG PROTOCOL. Sobre o Programa. Disponível em: <https://www.ghgprotocolbrasil.com.br/>. Acesso em: 10 abr. 2018.

REQUIÃO, Rubens. Curso de direito comercial. São Paulo: Saraiva, 2003.

SAATY, T. L. Scaling method for priorities in hierarchical structures. Journal of Mathematical Psychology, v.15, p.234-281. 1977.

SAATY, T. L. Physics as a decision theory. European Journal of Operational Research, v. 48, p.98-104. 1990.

SAATY, T. L. Método de análise hierárquica. São Paulo: Mc-Graw-Hill, Makron. 1991.

SAATY, T. L. Decision making for leaders. Pittsburg: RWS Publications. 2000.

SAATY, T. L.; Vargas, L. G. Models, methods, concepts \& applications of the analytic hierarchy process. $2^{\mathrm{a}}$ ed. New York: Springer. 2012.

SEBHATU, S.M. Sustainability Performance Measurement for sustainable organizations: beyond compliance and Reporting, 2011. 
SCHALTEGGER, S.; BURRITT, R.; PETERSEN, H. An introduction to corporate environmental management. Striving for sustainability. Sheffield, UK: Greenleaf, 2003.

SCHALTEGGER, S.; WAGNER, M. Integrative management of sustainability performance, measurement and reporting, International Journal of Accounting, Auditing and Performance Evaluation, v.3, n.1, p.1-19, 2006.

VAN MARREWIJK, M.; WERRE, M. Multiple levels of corporate sustainability. Journal of Business Ethics, v. 44; n.2-3; p.107-119, 2003.

VERGARA, S. C. Projetos e relatórios de pesquisa em administração. 4 ed. São Paulo: Atlas, 2003.

WBCSD. World Business Council for Sustainable Development. Social responsibility: making good business sense. Jan 2000. Disponível em: $<$ http://www.wbcsd.ch/DocRoot/IunSPdIKvmYH5HjbN4XC/csr2000.pdf>.

Acesso em: 10 abr. 2018.

WOOD, D. J. Measuring corporate social performance: a review. International Journal of Management Review, v.12, n.1, p.50-84, 2010.

WORLD COMMISSION ON ENVIRONMENT AND DEVELOPMENT. WCED. Our common future. Oxford: Oxford University Press, 1987.

YOON, K. P.; HWANG, C. Multiple attribute decision making: an introduction. California: Sage Publications. 1995.

ZADEK, S. Balancing performance, ethics and accountability. Journal of Business Ethics. v.17, p.1421-1442. 1998.

ZADEK, S. The path to corporate responsibility. Harvard Business Review, v. 82, n.12, p.125-32, 2004. 


\section{Anexo 1 - Indicadores de sustentabilidade conforme Diretrizes G4 da GRI}

Listam-se neste anexo os 91 indicadores de sustentabilidade, conforme Diretrizes G4 da GRI, classificados por categoria/subcategoria.

Os indicadores fornecem informações sobre o desempenho ou impactos econômicos, ambientais e sociais da organização relacionados aos seus aspectos materiais. Aspectos materiais são aqueles que refletem impactos econômicos, ambientais e sociais significativos da organização ou influenciam substancialmente as avaliações e decisões de stakeholders.

\section{Categoria 'Econômica'}

\begin{tabular}{|l|l|}
\hline AM1 - Desempenho econômico & EC1 a EC4 \\
\hline AM2 - Presença no mercado & EC5 e EC6 \\
\hline AM3 - Impactos econômicos indiretos & EC7 e EC8 \\
\hline AM4 - Práticas de compra & EC9 \\
\hline
\end{tabular}

EC1 - Valor econômico direto gerado e distribuído

EC2 - Implicações financeiras e outros riscos e oportunidades para as atividades da organização em decorrência de mudanças climáticas

EC3 - Cobertura das obrigações previstas no plano de pensão de benefício definido da organização.

EC4 - Assistência financeira recebida do governo.

EC5 - Variação da proporção do salário mais baixo, discriminado por gênero, comparado ao salário mínimo local em unidades operacionais importantes.

EC6 - Proporção de membros da alta direção contratados na comunidade local em unidades operacionais importantes.

EC7 - Desenvolvimento e impacto de investimentos em infraestrutura e serviços oferecidos.

EC8 - Impactos econômicos indiretos significativos, inclusive a extensão dos impactos.

EC9 - Proporção de gastos com fornecedores locais em unidades operacionais importantes. 


\section{Categoria 'Ambiental'}

\begin{tabular}{|l|l|}
\hline AM5 - Materiais & EN1 e EN2 \\
\hline AM6 - Energia & EN3 a EN7 \\
\hline AM7 - Água & EN8 a EN10 \\
\hline AM8 - Biodiversidade & EN11 a EN14 \\
\hline AM9 - Emissões & EN15 a EN21 \\
\hline AM10 - Efluentes e resíduos & EN22 a EN26 \\
\hline AM11 - Produtos e serviços & EN27 e EN28 \\
\hline AM12 - Conformidade & EN29 \\
\hline AM13 - Transportes & EN30 \\
\hline AM14 - Geral & EN31 \\
\hline AM15 - Avaliação ambiental de fornecedores & EN32 e EN33 \\
\hline $\begin{array}{l}\text { AM16 - Mecanismos de queixas e reclamações } \\
\text { relacionadas a impactos ambientais }\end{array}$ & EN34 \\
\hline
\end{tabular}

EN1 - Materiais usados, discriminados por peso ou volume

EN2 - Percentual de materiais usados provenientes de reciclagem

EN3 - Consumo de energia dentro da organização

EN4 - Consumo de energia fora da organização

EN5 - Intensidade energética

EN6 - Redução do consumo de energia

EN7 - Reduções nos requisitos de energia relacionados a produtos e serviços

EN8 - Total de retirada de água por fonte

EN9 - Fontes hídricas significativamente afetadas por retirada de água

EN10 - Percentual e volume total de água reciclada e reutilizada

EN11 - Unidades operacionais próprias, arrendadas ou administradas dentro ou nas adjacências de áreas protegidas e áreas de alto valor para a biodiversidade situadas fora de áreas protegidas.

EN12 - Descrição de impactos significativos de atividades, produtos e serviços sobre a biodiversidade em áreas protegidas e áreas de alto valor para a biodiversidade situadas fora de áreas protegidas.

EN13 - Habitats protegidos ou restaurados.

EN14 - Número total de espécies incluídas na lista vermelha da IUCN e em listas nacionais de conservação com habitats situados em áreas afetadas por operações da organização, discriminadas por nível de risco de extinção.

EN15 - Emissões diretas de gases de efeito estufa (GEE) (Escopo 1).

EN16 - Emissões indiretas de gases de efeito estufa (GEE) provenientes da aquisição de energia (Escopo 2).

EN17 - Outras emissões indiretas de gases de efeito estufa (GEE) (Escopo 3).

EN18 - Intensidade de emissões de gases de efeito estufa (GEE).

EN19 - Redução de emissões de gases de efeito estufa (GEE).

EN20 - Emissões de substâncias que destroem a camada de ozônio (SDO). 
EN21 - Emissões de NOx, SOx e outras emissões atmosféricas significativas.

EN22 - Descarte total de água, discriminado por qualidade e destinação.

EN23 - Peso total de resíduos, discriminado por tipo e método de disposição.

EN24 - Número total e volume de vazamentos significativos.

EN25 - Peso de resíduos transportados, importados, exportados ou tratados considerados perigosos nos termos da Convenção Da Basileia, Anexos I, Ii, Iii E Viii, e percentual de resíduos transportados internacionalmente.

EN26 - Identificação, tamanho, status de proteção e valor da biodiversidade de corpos d'água e habitats relacionados significativamente afetados por descartes e drenagem de água realizados pela organização.

EN27 - Extensão da mitigação de impactos ambientais de produtos e serviços.

EN28 - Percentual de produtos e suas embalagens recuperados em relação ao total de produtos vendidos, discriminado por categoria de produtos.

EN29 - Valor monetário de multas significativas e número total de sanções não monetárias aplicadas em decorrência da não conformidade com leis e regulamentos ambientais.

EN30 - Impactos ambientais significativos decorrentes do transporte de produtos e outros bens e materiais usados nas operações da organização, bem como do transporte de seus empregados.

EN31 - Total de investimentos e gastos com proteção ambiental, discriminado por tipo.

EN32 - Percentual de novos fornecedores selecionados com base em critérios ambientais.

EN33 - Impactos ambientais negativos significativos reais e potenciais na cadeia de fornecedores e medidas tomadas a esse respeito.

EN34 - Número de queixas e reclamações relacionadas a impactos ambientais protocoladas, processadas e solucionadas por meio de mecanismo formal.

\section{Categoria 'Social'}

\subsection{Subcategoria 'Práticas trabalhistas e trabalho decente'}

\begin{tabular}{|l|l|l|}
\hline \multirow{3}{*}{$\begin{array}{l}\text { Social/Práticas } \\
\text { drabalhistas e trabalho }\end{array}$} & AM17 - Emprego & LA1 a LA3 \\
\cline { 2 - 3 } & AM18 - Relações trabalhistas & LA4 \\
\cline { 2 - 3 } & AM19 - Saúde e segurança no trabalho & LA5 a LA8 \\
\cline { 2 - 3 } & AM20 - Treinamento e educação & LA9 a LA11 \\
\cline { 2 - 3 } & $\begin{array}{l}\text { AM21 - Diversidade e igualdade de } \\
\text { oportunidades }\end{array}$ & LA12 \\
\cline { 2 - 3 } & $\begin{array}{l}\text { AM22 - Igualdade de remuneração entre homens } \\
\text { e mulheres }\end{array}$ & LA13 \\
\cline { 2 - 3 } & $\begin{array}{l}\text { AM23 - Avaliação de fornecedores em práticas } \\
\text { trabalhistas }\end{array}$ & LA14 e LA15 \\
\cline { 2 - 3 } & $\begin{array}{l}\text { AM24 - Mecanismos de queixas e reclamações } \\
\text { relacionadas a práticas trabalhistas }\end{array}$ & LA16 \\
\hline
\end{tabular}

LA1 - Número total e taxas de novas contratações de empregados e rotatividade por faixa etária, gênero e região. 
LA2 - Benefícios concedidos a empregados de tempo integral que não são oferecidos a empregados temporários ou em regime de meio período, discriminados por unidades operacionais importantes da organização.

LA3 - Taxas de retorno ao trabalho e retenção após licença maternidade/paternidade, discriminadas por gênero.

LA4 - Prazo mínimo de notificação sobre mudanças operacionais e se elas são especificadas em acordos de negociação coletiva.

LA5 - Percentual da força de trabalho representada em comitês formais de saúde e segurança, compostos por empregados de diferentes níveis hierárquicos, que ajudam a monitorar e orientar programas de saúde e segurança no trabalho.

LA6 - Tipos e taxas de lesões, doenças ocupacionais, dias perdidos, absenteísmo e número de óbitos relacionados ao trabalho, discriminados por região e gênero.

LA7 - Empregados com alta incidência ou alto risco de doenças relacionadas à sua ocupação.

LA8 - Tópicos relativos à saúde e segurança cobertos por acordos formais com sindicatos.

LA9 - Número médio de horas de treinamento por ano por empregado, discriminado por gênero e categoria funcional.

LA10 - Programas de gestão de competências e aprendizagem contínua que contribuem para a continuidade da empregabilidade dos empregados em período de preparação para a aposentadoria.

LA11 - Percentual de empregados que recebem regularmente análises de desempenho e de desenvolvimento de carreira, discriminado por gênero e categoria funcional.

LA12 - Composição dos grupos responsáveis pela governança e discriminação de empregados por categoria funcional, de acordo com gênero, faixa etária, minorias e outros indicadores de diversidade.

LA13 - Razão matemática do salário e remuneração entre mulheres e homens, discriminada por categoria funcional e unidades operacionais relevantes.

LA14 - Percentual de novos fornecedores selecionados com base em critérios relativos a práticas trabalhistas.

LA15 - Impactos negativos significativos reais e potenciais para as práticas trabalhistas na cadeia de fornecedores e medidas tomadas a esse respeito.

\subsection{Subcategoria 'Direitos humanos'}

\begin{tabular}{|l|l|l|}
\hline \multirow{4}{*}{$\begin{array}{l}\text { Social/Direitos } \\
\text { humanos }\end{array}$} & HM25 - Investimento & HR3 \\
\cline { 2 - 3 } & AM26 - Não discriminação & HR2 \\
\cline { 2 - 3 } & $\begin{array}{l}\text { AM27 - Liberdade de associação e negociação } \\
\text { coletiva }\end{array}$ & HR4 \\
\cline { 2 - 3 } & AM28 - Trabalho infantil & HR5 \\
\cline { 2 - 3 } & AM29 - Trabalho forçado ou análogo ao escravo & HR6 \\
\cline { 2 - 3 } & AM30 - Práticas de segurança & HR7 \\
\hline & AM31 - Direitos indígenas & HR8 \\
\hline & AM32 - Avaliação & HR9 \\
\hline & $\begin{array}{l}\text { AM33 - Avaliação de fornecedores em direitos } \\
\text { humanos }\end{array}$ & HR10 e HR11 \\
\cline { 2 - 3 } & $\begin{array}{l}\text { AM34 - Mecanismos de queixas e reclamações } \\
\text { relacionadas a direitos humanos }\end{array}$ & HR12 \\
\hline
\end{tabular}


HR1 - Número total e percentual de acordos e contratos de investimentos significativos que incluem cláusulas de direitos humanos ou que foram submetidos a avaliação referente a direitos humanos.

HR2 - Número total de horas de treinamento de empregados em políticas de direitos humanos ou procedimentos relacionados a aspectos de direitos humanos relevantes para as operações da organização, incluindo o percentual de empregados treinados.

HR3 - Número total de casos de discriminação e medidas corretivas tomadas.

HR4 - Operações e fornecedores identificados em que o direito de exercer a liberdade de associação e a negociação coletiva possa estar sendo violado Ou Haja Risco Significativo E As Medidas Tomadas Para Apoiar Esse Direito.

HR5 - Operações e fornecedores identificados como de risco para a ocorrência de casos de trabalho infantil e medidas tomadas para contribuir para a efetiva erradicação do trabalho infantil.

HR6 - Operações e fornecedores identificados como de risco significativo para a ocorrência de trabalho forçado ou análogo ao escravo e medidas tomadas para contribuir para a eliminação de todas as formas de trabalho forçado ou análogo ao escravo.

HR7 - Percentual do pessoal de segurança que recebeu treinamento nas políticas ou procedimentos da organização relativos a direitos humanos que sejam relevantes às operações.

HR8 - Número total de casos de violação de direitos de povos indígenas e tradicionais e medidas tomadas a esse respeito.

HR9 - Número total e percentual de operações submetidas a análises ou avaliações de direitos humanos de impactos relacionados a direitos humanos.

HR10 - Percentual de novos fornecedores selecionados com base em critérios relacionados aos direitos humanos.

HR11 - Impactos negativos significativos reais e potenciais em direitos humanos na cadeia de fornecedores e medidas tomadas a esse respeito.

HR12 - Número de queixas e reclamações relacionadas a impactos em direitos humanos registradas, processadas e solucionadas por meio de mecanismo forma.

\subsection{Subcategoria 'Sociedade'}

\begin{tabular}{|l|l|l|}
\hline Social/Sociedade & AM35 - Comunidades locais & SO1 e SO2 \\
\cline { 2 - 3 } & AM36 - Combate à corrupção & SO3 a SO5 \\
\cline { 2 - 3 } & AM37 - Políticas públicas & SO6 \\
\cline { 2 - 3 } & AM38 - Concorrência desleal & SO7 \\
\cline { 2 - 3 } & AM39 - Conformidade & SO8 \\
\cline { 2 - 3 } & $\begin{array}{l}\text { AM40 - Avaliação de fornecedores em impactos } \\
\text { na sociedade }\end{array}$ & SO9 e SO10 \\
\cline { 2 - 3 } & $\begin{array}{l}\text { AM41 - Mecanismos de queixas e reclamações } \\
\text { relacionadas a impactos na sociedade }\end{array}$ & SO11 \\
\hline
\end{tabular}

so1 - Percentual de operações com programas implementados de engajamento da comunidade local, avaliação de impactos e desenvolvimento local.

SO2 - Operações com impactos negativos significativos reais e potenciais nas comunidades locais. 
SO3 - Número total e percentual de operações submetidas a avaliações de riscos relacionados à corrupção e os riscos significativos identificados.

so4 - Comunicação e treinamento em políticas e procedimentos de combate à corrupção.

SO5 - Casos confirmados de corrupção e medidas tomadas.

SO6 - valor total de contribuições financeiras para partidos políticos e políticos, discriminado por país e destinatário/beneficiário.

so7- Número total de ações judiciais movidas por concorrência desleal, práticas de truste e monopólio e seus resultados.

s08 - Valor monetário de multas significativas e número total de sanções não monetárias aplicadas em decorrência da não conformidade com leis e regulamentos.

so9 - Percentual de novos fornecedores selecionados com base em critérios relativos a impactos na sociedade.

s010 - Impactos negativos significativos reais e potenciais da cadeia de fornecedores na sociedade e medidas tomadas a esse respeito.

so11 - Número de queixas e reclamações relacionadas a impactos na sociedade registradas, processadas e solucionadas por meio de mecanismo formal.

\subsection{Subcategoria 'Responsabilidade sobre o produto'}

\begin{tabular}{|l|l|l|}
\hline \multirow{3}{*}{$\begin{array}{l}\text { Social/Responsabilidade } \\
\text { sobre o produto }\end{array}$} & AM42 - Saúde e segurança do cliente & PR1 e PR2 \\
\cline { 2 - 3 } & AM43 - Rotulagem de produtos e serviços & PR3 a PR5 \\
\cline { 2 - 3 } & AM44 - Comunicações de marketing & PR6 e PR7 \\
\cline { 2 - 3 } & AM45 - Privacidade do cliente & PR8 \\
\cline { 2 - 3 } & AM46 - Conformidade & PR9 \\
\hline
\end{tabular}

PR1 - Percentual das categorias de produtos e serviços significativas para as quais são avaliados impactos na saúde e segurança buscando melhorias.

PR2 - Número total de casos de não conformidade com regulamentos e códigos voluntários relacionados aos impactos causados por produtos e serviços na saúde e segurança durante seu ciclo de vida, discriminado por tipo de resultado.

PR3 - Tipo de informações sobre produtos e serviços exigidas pelos procedimentos da organização referentes a informações e rotulagem de produtos e serviços e percentual de categorias significativas sujeitas a essas exigências.

PR4 - Número total de casos de não conformidade com regulamentos e códigos voluntários relativos a informações e rotulagem de produtos e serviços, discriminado por tipo de resultado.

PR5 - Resultados de pesquisas de satisfação do cliente.

PR6 - Venda de produtos proibidos ou contestados.

PR7 - Número total de casos de não conformidade com regulamentos e códigos voluntários relativos a comunicações de marketing, incluindo publicidade, promoção e patrocínio, discriminados por tipo de resultados.

PR8 - Número total de queixas e reclamações comprovadas relativas à violação de privacidade e perda de dados de clientes.

PR9 - Valor monetário de multas significativas por não conformidade com leis e regulamentos relativos ao fornecimento e uso de produtos e serviços. 


\section{Apêndice 1 - Métodos multicritério de apoio à decisão adotados na pesquisa}

Este apêndice descreve os métodos AHP e TOPSIS, ambos adotados na modelagem e no estudo empírico que integram a presente pesquisa. As descrições a seguir são partes integrantes de pesquisa anterior do Programa Pós-MQI da PUC-Rio (Mello, 2015).

\section{Método AHP}

O método AHP, conforme proposto por Saaty $(1977 ; 1990 ; 1991 ; 2000)$, compreende quatro etapas:

- Organização da estrutura hierárquica, por meio da identificação do foco principal, dos critérios e subcritérios (quando existirem) e das alternativas, refletindo as relações existentes entre eles;

- Aquisição dos dados e coleta de julgamentos de valor, por meio da comparação dos elementos dois a dois e estabelecimento das matrizes de comparações;

- Análise das matrizes de comparações geradas na fase anterior, que indicarão a prioridade de cada alternativa em relação ao foco principal;

- Análise dos indicadores de desempenho derivados, como índices de consistência por exemplo.

De acordo com o método AHP, os elementos de uma hierarquia para a resolução de problemas de decisão são o foco principal (ou meta), o conjunto de alternativas viáveis e o conjunto de critérios, de acordo com o ilustrado na figura A.1.

O foco principal é o objetivo global, o que a resolução do problema trará. As alternativas viáveis são as possibilidades de escolha dentro do problema para que a decisão seja tomada. Por fim, os critérios são as características ou propriedades a partir das quais as alternativas devem ser avaliadas. 


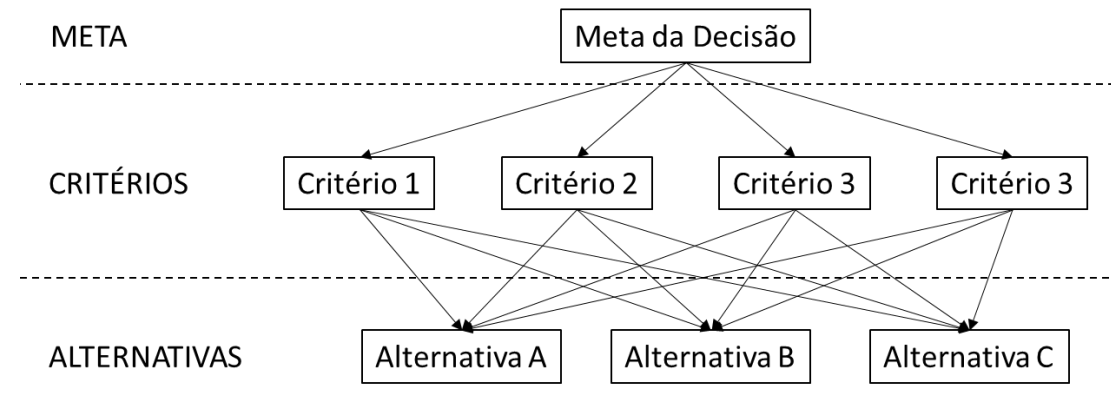

Figura A.1 - Exemplo de estrutura hierárquica de problemas de decisão (em três níveis) Fonte: Saaty, 1991.

Após a hierarquização, o método aponta para os julgamentos de valor, em que o avaliador deve comparar os elementos dois a dois à luz de um determinado critério. O julgamento é, então, a representação numérica dessa relação e o grupo de todos os julgamentos, considerando a comparação de todos os elementos em relação a um critério específico, pode ser representado por meio de uma matriz quadrada (Saaty, 1977; 1990; 1991; 2000).

Para o estabelecimento do processo de julgamento, Saaty definiu uma escala específica para padronizar os julgamentos de valor, escala essa que capta a subjetividade natural existente em variáveis qualitativas. O quadro A.1, a seguir, apresenta essa escala.

Quadro A.1 - Escala para padronizar os julgamentos de valor pelo método AHP

\begin{tabular}{|l|l|l|}
\hline $\begin{array}{l}\text { Intensidade de } \\
\text { importância }\end{array}$ & Definição & Explicação \\
\hline 1 & Mesma importância & $\begin{array}{l}\text { As duas atividades contribuem igualmente para } \\
\text { o objetivo. }\end{array}$ \\
\hline 3 & $\begin{array}{l}\text { Importância moderada } \\
\text { de uma sobre a outra }\end{array}$ & $\begin{array}{l}\text { A experiência e o julgamento favorecem } \\
\text { levemente uma atividade em relação à outra. }\end{array}$ \\
\hline 5 & $\begin{array}{l}\text { Importância grande ou } \\
\text { essencial }\end{array}$ & $\begin{array}{l}\text { A experiência e o julgamento favorecem } \\
\text { fortemente uma atividade em relação à outra. }\end{array}$ \\
\hline 7 & $\begin{array}{l}\text { Importância muito } \\
\text { grande ou } \\
\text { demonstrada }\end{array}$ & $\begin{array}{l}\text { Uma atividade é muito fortemente favorecida em } \\
\text { relação à outra; sua dominação de importância é } \\
\text { demosntrada na prática. }\end{array}$ \\
\hline 9 & $\begin{array}{l}\text { Importância absoluta } \\
\text { à evidência favorece uma atividade em relação }\end{array}$ \\
\hline $2,4,6,8$ & $\begin{array}{l}\text { Valores intermediários o mais alto grau de certeza. } \\
\text { entre os valores } \\
\text { adjacentes. }\end{array}$ & $\begin{array}{l}\text { Quando se procura uma condição de } \\
\text { compromisso entre as duas definições. }\end{array}$ \\
\hline
\end{tabular}

Fonte: Saaty, 1991. 
O julgamento consiste no reflexo de duas perguntas: qual dos dois elementos é o mais importante, à luz do objetivo pretendido, e com qual intensidade ele é mais importante, utilizando-se a escala de 1 a 9 apresentada no quadro A.1.

Para o elemento mais importante, é utilizado um valor inteiro, enquanto que o menos importante recebe o inverso dessa unidade, como ilustrado no exemplo didático da figura A.2.

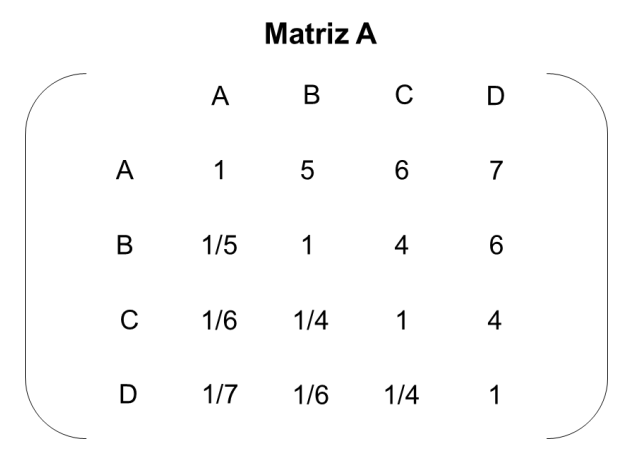

Figura A.2 - Exemplo de matriz de julgamentos pelo método AHP Fonte: Saaty, 1991.

As letras A, B, C e D representam os elementos a serem comparados dois a dois. A diagonal da matriz recebe sempre 1, pois é a comparação do elemento com ele mesmo. Para o preenchimento dos outros campos, são feitos os julgamentos para determinar a intensidade de importância, utilizando a escala determinada por Saaty. Para as comparações inversas, ou seja, o que está na parte inferior esquerda da matriz, são adicionados os valores recíprocos referentes a cada julgamento, que estão na parte superior direita da mesma.

Com as matrizes recíprocas devidamente estruturadas, obtém-se o vetor de prioridades, ou pesos, a partir do cálculo do autovetor normalizado do máximo autovalor. Existem métodos específicos para o cálculo aproximado desses valores (Saaty, 1991). Tais aproximações foram desenvolvidas por limitações computacionais da época em que o método foi desenvolvido, sendo custoso o cálculo de autovetores e autovalores para matrizes de ordem elevada.

Para fins desta pesquisa, será utilizado o valor preciso de ambas as grandezas, que são denotadas matricialmente por:

$$
A w=\lambda_{\max } w
$$

Onde:

$A$ é a matriz de julgamentos (quadrada, recíproca e positiva);

$w$ é o autovetor principal, referente aos pesos;

$\lambda_{\text {max }}$ é o autovalor principal de $A$. 
Com as características das matrizes de julgamentos em mãos, e com base no teorema de Perron-Frobenius, Saaty (1991) afirma que a solução tem um único autovalor maior, que corresponde a um autovetor de componentes estritamente positivos. Os teoremas e as provas acerca das características envolvendo as matrizes geradas, a partir da avaliação de especialistas, são apresentados em seu trabalho. Computados os autovalores das respectivas matrizes, é necessário realizar análise da consistência dos julgamentos para avaliar o quão afastado da consistência os julgamentos estão.

Utiliza-se uma medida para avaliar a probabilidade de os julgamentos terem sido realizados puramente ao acaso e esta medida é chamada Razão de Consistência (RC). Por exemplo, um $R C=0,3$ diz que há $30 \%$ de chance do especialista responder as perguntas aleatoriamente.

Saaty (1991) apresenta um desenvolvimento simples e intuitivo para compreender a análise de consistência. Supondo-se uma matriz consistente, em que as comparações são baseadas em medidas exatas, isto é, os pesos já são conhecidos, então:

$$
a_{i j}=\frac{w_{i}}{w_{j}}
$$

Como o julgamento é perfeito para todas as comparações, tem-se que: $a_{i k}=a_{i j} \cdot a_{j k}$ para qualquer $\mathrm{i}, \mathrm{j}, \mathrm{k}$, variando de 1 até $n$, sendo $n$ a ordem da matriz.

Também vale a afirmativa:

$$
a_{i j}=\frac{w_{j}}{w_{i}}=\frac{1}{w_{i} / w_{j}}=\frac{1}{a_{i j}}
$$

Dessa forma, caracteriza-se uma matriz consistente de comparações pareadas.

Considerando $x=\left(x_{1}, \ldots, x_{n}\right)$ e $y=\left(y_{1}, \ldots, y_{n}\right)$, pode-se escrever em notação matricial $A \cdot x=y$, onde A é a matriz de julgamentos:

$$
A=\left[\begin{array}{ccc}
\frac{w_{1}}{w_{1}} & \cdots & \frac{w_{1}}{w_{n}} \\
\vdots & \ddots & \vdots \\
\frac{w_{n}}{w_{1}} & \cdots & \frac{w_{n}}{w_{n}}
\end{array}\right]
$$


Algebricamente, essa operação pode ser representada por:

$$
\begin{aligned}
& \sum_{j=0}^{n} a_{i j} \cdot x_{i}=y_{i} \\
& \operatorname{para} i=1, \ldots, n
\end{aligned}
$$

Como $a_{i j}=\frac{w_{i}}{w_{j}}$, obtém-se:

$$
a_{i j} \frac{w_{j}}{w_{i}}=1
$$

$$
\text { para } i, j=1, \ldots, n
$$

Consequentemente:

$$
\begin{gathered}
\sum_{j=0}^{n} a_{i j} \cdot w_{j} \frac{1}{w_{i}}=n \\
\quad \operatorname{para} i=1, \ldots, n
\end{gathered}
$$

$\mathrm{Ou}$

$$
\begin{gathered}
\sum_{j=0}^{n} a_{i j} \cdot w_{j}=n w_{i} \\
\operatorname{para} i=1, \ldots, n
\end{gathered}
$$

Que é equivalente a equação matricial:

$$
A w=n w
$$

Em álgebra linear, esta última equação expressa o fato de que $w$ é autovetor de $A$ com autovalor $n$.

Na prática, $a_{i j}$ são os pesos atribuídos pelo julgamento dos especialistas, baseado na escala fundamental, e de certa forma subjetivos. Assim, os valores $a_{i j}$ irão se afastar do "ideal" $w_{i} / w_{j}$, fazendo com que a equação $A w=n w$ não seja mais válida.

Se $\lambda_{1}, \ldots, \lambda_{n}$ são os números que satisfazem a equação $A w=\lambda w$, então $\lambda$ é autovalor de $A$ e, se $a_{i j}=1$ para todo i, então:

$$
\sum_{i=0}^{n} \lambda_{i}=n
$$

Assim, se $A w=n w$ é válida, somente um dos autovalores é diferente de zero e valerá $n$, sendo o maior autovalor de $A$. 
Caso os elementos de uma matriz recíproca positiva sofrerem pequenas variações, seus respectivos autovalores também variarão em pequenas quantidades.

Utilizando os resultados apresentados juntamente com o axioma anterior, pode-se dizer que, caso a diagonal principal de uma matriz possua os elementos iguais a 1 e for consistente, pequenas variações nos elementos $a_{i j}$ farão com que o autovalor máximo $\lambda_{\max }$ permaneça próximo de $n$ e os outros autovalores próximos de zero, sendo $\lambda_{\max } \geq n$.

Portanto, para calcular o autovetor de prioridades de uma matriz de comparações pareadas $A$, deve-se encontrar o vetor que satisfaça a equação $A w=$ $\lambda_{\max } w$.

O valor de interesse para o desenvolvimento da metodologia é o autovetor normalizado, de forma que a soma de $w$ seja igual a 1. Para isso, cada elemento $w_{i}$ é dividido pelo seu somatório.

Uma medida de consistência, chamada Índice de Consistência (IC), é utilizada para calcular o desvio de $\lambda_{\max }$ em relação a $n$, uma vez que a utilização da escala para os julgamentos geram variações em $a_{i j}$, alterando $\lambda_{\max }$.

$$
I C=\frac{\lambda_{\max }-n}{n-1}
$$

É comum as avaliações realizadas pelos especialistas gerarem inconsistências, pois fazem parte do julgamento humano, mas deseja-se que sejam as menores possíveis. Para verificar a coerência, utiliza-se, como citado anteriormente, a Razão de Consistência, tendo como definição:

$$
R C=\frac{I C}{I R}
$$

Onde: IR (Índice Randômico) é o índice de consistência de uma matriz recíproca gerada randomicamente, baseada na escala de 1 a 9, com recíprocas forçadas (Saaty e Vargas, 2012). Este valor é tabelado e varia de acordo com a ordem da matriz.

A avaliação final da coerência do julgamento se dá ao comparar o valor de RC. Para o presente desenvolvimento, fazem-se as seguintes considerações:

a) $R C \leq 0,1$ consiste em um julgamento coerente, premissa básica do método em relação a análise de coerência, proposta inicialmente para julgar uma avaliação como satisfatória; 
b) $0,1<R C<0,2=$ Julgamento questionável, considerado para que especialista reveja seus julgamentos da respectiva etapa, analisando a matriz construída e busque melhorar alguma(s) comparação(ões) que tenha(m) sido inconsistente(s). Porém, não é obrigatório que se altere algum julgamento;

c) $R C \geq 0,2=$ Julgamento incoerente, indica que as comparações pareadas daquela etapa geraram um alto índice de inconsistência e o especialista é obrigado a refazer seus julgamentos.

Uma vez alcançada a consistência no julgamento, são calculados os vetores de prioridades, ou seja, os pesos relativos de cada elemento do problema. Este cálculo é realizado por meio da multiplicação das matrizes de prioridades. Em outras palavras, para cada alternativa, o cálculo consiste na soma ponderada da importância relativa de cada atributo pelo nível de preferência de determinada alternativa em relação ao respectivo critério. No AHP, cada alternativa receberá uma pontuação por meio de uma função de valor aditiva. As alternativas com maior valor serão as preferíveis. Formalizando, a função de valor para cada alternativa será:

$$
F(a)=\sum_{j=1}^{n} w_{j} v_{j}(a)
$$

Onde:

$F(a)$ é o valor final de alternativa $a$;

$w_{j}$ é o peso do j-ésimo critério;

$v_{j}$ é o desempenho da alternativa em relação ao j-ésimo critério.

\section{Método TOPSIS}

Nesta seção, descreve-se o método para avaliar o desempenho de alternativas pela similaridade com a solução ideal (TOPSIS), conforme proposto por Hwang e Yoon, (1981). Basicamente, a técnica compreende as seguintes etapas:

- Construção da matriz do problema ou matriz de decisão, que traz as alternativas e critérios selecionados juntamente com as notas e avaliações;

- Cálculo da matriz normalizada, utilizando normalização linear ou por vetor;

- Cálculo da matriz com os respectivos pesos de cada critério, definidos previamente por um ou mais decisores; 
- Identificação da PIS e da NIS;

- Cálculo das distâncias entre a PIS e cada alternativa e entre a NIS e cada alternativa;

- Cálculo da similaridade para a posição ideal positiva, que vai definir a hierarquização das alternativas estudadas.

A matriz de decisão A composta por alternativas e critérios é apresentada a seguir:

$$
\begin{aligned}
& C_{1} \quad \cdots \quad C_{n} \\
& A=\begin{array}{c}
A_{1} \\
\cdots \\
A_{m}
\end{array}\left(\begin{array}{ccc}
x_{11} & \ldots & x_{1 n} \\
\vdots & \ddots & \vdots \\
x_{m 1} & \cdots & x_{m m}
\end{array}\right)
\end{aligned}
$$

onde $A_{1}, A_{2}, \ldots . A_{m}$ são alternativas viáveis e $C_{1}, C_{2}, \ldots . ., C_{n}$ são critérios; $x_{i j}$ indica o desempenho da alternativa $A_{i}$ segundo o critério $C_{\mathrm{j}}$.

$\mathrm{O}$ vetor de peso $W=\left(w_{1}, w_{2}, \ldots . w_{n}\right)$ composto pelos pesos individuais para cada critério $C_{j}$ satisfaz:

$$
\sum_{i=1}^{n} w_{j}=1
$$

Os dados da matriz A têm origens distintas, devendo ser normalizada com o objetivo de transformá-la em uma matriz adimensional e, com isso, proceder a uma comparação entre os vários critérios. Para fins de aplicação nesta pesquisa, a matriz A deve ser normalizada para cada critério $C_{j}$, de acordo com a seguinte fórmula:

$$
\begin{gathered}
p_{i j}={ }^{x_{i j}} / \sum_{i=1}^{m} x_{i j} \\
\operatorname{com} i=1, \ldots, m, j=1, \ldots, n .
\end{gathered}
$$

Assim, uma matriz de decisão normalizada $A_{n}$ representa o desempenho relativo das alternativas e pode ser descrita por:

$$
A_{n=}\left(p_{i j}\right)_{m x n}, \operatorname{com} i=1, \ldots, m \text { e } j=1, \ldots, n .
$$

O algoritmo, para calcular a melhor alternativa, segundo a técnica TOPSIS, compreende os seguintes passos (Krohling e Souza, 2011):

Passo 1: Cálculo das soluções ideais positivas $\mathrm{A}^{+}$(benefícios) e das soluções ideais negativas $\mathrm{A}^{-}$(custos) da seguinte forma:

$$
A^{+}=\left(p_{1}^{+}, p_{2}^{+}, \ldots, p_{m}^{+}\right)
$$




$$
A^{-}=\left(p_{1}^{-}, p_{2}^{-}, \ldots, p_{m}^{-}\right)
$$

Onde:

$$
\begin{aligned}
& p_{j}^{+}=\left(\max _{i} \cdot p_{i j}, j \in J_{1} ; \min _{i} \cdot p_{i j}, j \in J_{2}\right) \\
& p_{j}^{-}=\left(\min _{i} \cdot p_{i j}, j \in J_{1} ; \max _{i} \cdot p_{i j}, j \in J_{2}\right)
\end{aligned}
$$

onde $J_{1}$ e $J_{2}$ representam respectivamente o critério benefício e custo.

Passo 2: Cálculo das distâncias Euclidianas entre $A_{i}$ e $A^{+}$(benefícios) e entre $A_{i}$ e $A^{-}$(custos) da seguinte forma:

$$
\begin{aligned}
& d^{+}=\sqrt{\sum_{j=1}^{n} w_{j}\left(p_{j}^{+}-p_{i j}\right)^{2}}, \operatorname{com} i=1, \ldots, m \\
& d^{-}=\sqrt{\sum_{j=1}^{n} w_{j}\left(p_{j}^{-}-p_{i j}\right)^{2}}, \operatorname{com} i=1, \ldots, m
\end{aligned}
$$

Passo 2: Cálculo da proximidade relativa $\xi_{i}$ para cada alternativa $A_{i}$ em relação à solução ideal positiva $A^{+}$conforme:

$$
\xi_{i}=\frac{d_{i}^{-}}{d_{i}^{+}+d_{i}^{-}}
$$

\section{Referências bibliográficas do Apêndice 1}

COSTA, H. G. Auxílio multicritério à decisão: método AHP. Rio de Janeiro: Abepro. 2006.

HWANG, C. L. YOON, K. Multiple attribute decision making: methods and applications, New York: Springer-Verlag. 1981.

KROHLING, R.A.; SOUZA, T.T.M. Dois exemplos da aplicação da técnica TOPSIS para tomada de decisão. Revista de Sistemas de Informação da FSMA, n. 8, p. 31-35, 2011.

MELLO, A. F. P. Monitoramento e avaliação da regulamentação sobre recolhimento de alimentos no Brasil: proposição de indicadores e métricas. 2015. 185p. Dissertação (Mestrado). Programa de Pós-graduação em Metrologia. Pontificia Universidade Católica do Rio de Janeiro. Rio de Janeiro, 2015.

SAATY, T. L. Decision making for leaders. Pittsburg: RWS Publications. 2000.

SAATY, T. L. Método de análise hierárquica. São Paulo: Mc-Graw-Hill, Makron. 1991.

SAATY, T. L. Physics as a decision theory. European Journal of Operational Research, v. 48, p.98-104. 1990.

SAATY, T. L. Scaling method for priorities in hierarchical structures. Journal of Mathematical Psychology, v.15, p.234-281. 1977.

SAATY, T. L.; Vargas, L. G. Models, methods, concepts \& applications of the analytic hierarchy process. $2^{\mathrm{a}}$ ed. New York: Springer. 2012. 


\section{Apêndice 2 - Agenda, roteiro e síntese das entrevistas no Grupo Algar}

Neste apêndice 2, apresentam-se a agenda, o roteiro e a síntese de dez entrevistas realizadas pelo pesquisador e sua orientadora junto a gestores do Grupo Algar, durante os dias 17 e 23 de agosto de 2017.

\section{Agenda}

\section{Dia 18/08/2017 (sexta-feira)}

- Entrevista 3: 09h00 - Cristiana Heluy (Responsável pela área de sustentabilidade da Algar Telecom)

- Entrevista 4: 10h30 - Estela Lisboa (responsável pela área de sustentabilidade da Algar Tech

- Entrevista 5: 12h15 - Neide Aparecida Gonçalves (Gerente de Projetos do Rio Quente Resorts)

- Entrevista 6: 13h15 - Carolina Toffoli Rodrigues e Camila Fioranelli (Coordenadoras no Instituto Algar)

- Entrevista 7: 15 h30 - Cléver Roberto Assunção da Silva (Responsável pela área de sustentabilidade da Algar Farming/Agro)

\section{Dia 23/08/2017 (quarta-feira)}

- Entrevista 8: 10h15 - Clau Sganzerla (Vice-Presidente de Estratégia e Inovação Grupo Algar)

- Entrevista 9: 14h00 - Luciana Vasconcelos (Vice-Presidente de Finanças Grupo Algar)

- Entrevista 10: 14h30 - Luiz Alexandre Garcia (Presidente Executivo do Grupo Algar)

\section{Roteiro das entrevistas}

\subsection{Objetivo}

Esta entrevista faz parte da pesquisa de campo de um projeto de mestrado em desenvolvimento na PUC-Rio, com o objetivo de propor um modelo de monitoramento e avaliação de desempenho em sustentabilidade para grupos multissetoriais, tendo como ambiente de validação empírica desse modelo o contexto corporativo do Grupo Algar. Para fins desta pesquisa, definem-se grupos multissetoriais como estruturas corporativas que atuam em dois ou mais setores 
econômicos, normalmente no formato de participações diversificadas e não necessariamente majoritárias. Adota-se o conceito de sustentabilidade, conforme as Diretrizes G4, divulgadas pela Global Reporting Initiative.

2.2 Duração prevista de cada entrevista: 45 - 60 min.

\subsection{Questões}

\section{PARTE 1: MATRIZ DE MATERIALIDADE}

1. Você considera que o processo de escolha dos aspectos materiais de maior relevância para o Grupo Algar e seus stakeholders poderia ser melhorado, em função do Grupo ser multissetorial e atuar em diversos contextos socioprodutivos, com diferentes stakeholders em cada um desses contextos?

2. Em caso afirmativo, que melhorias você sugere? Uso de ferramentas multicritério de apoio à decisão? Análise de estudos setoriais? Alinhamento a referenciais de sustentabilidade para setores em que o Grupo Algar atua?

3. Em uma primeira análise da "Matriz de Materialidade" constante do Relatório de Sustentabilidade - 2016, observou-se dentre os dez aspectos materiais situados no quadrante superior direito, sete são associados a atendimento a leis, regulamentos e normas. Um segundo aspecto que chamou atenção é a ênfase em temas sociais (oito dos dez temas mais relevantes).
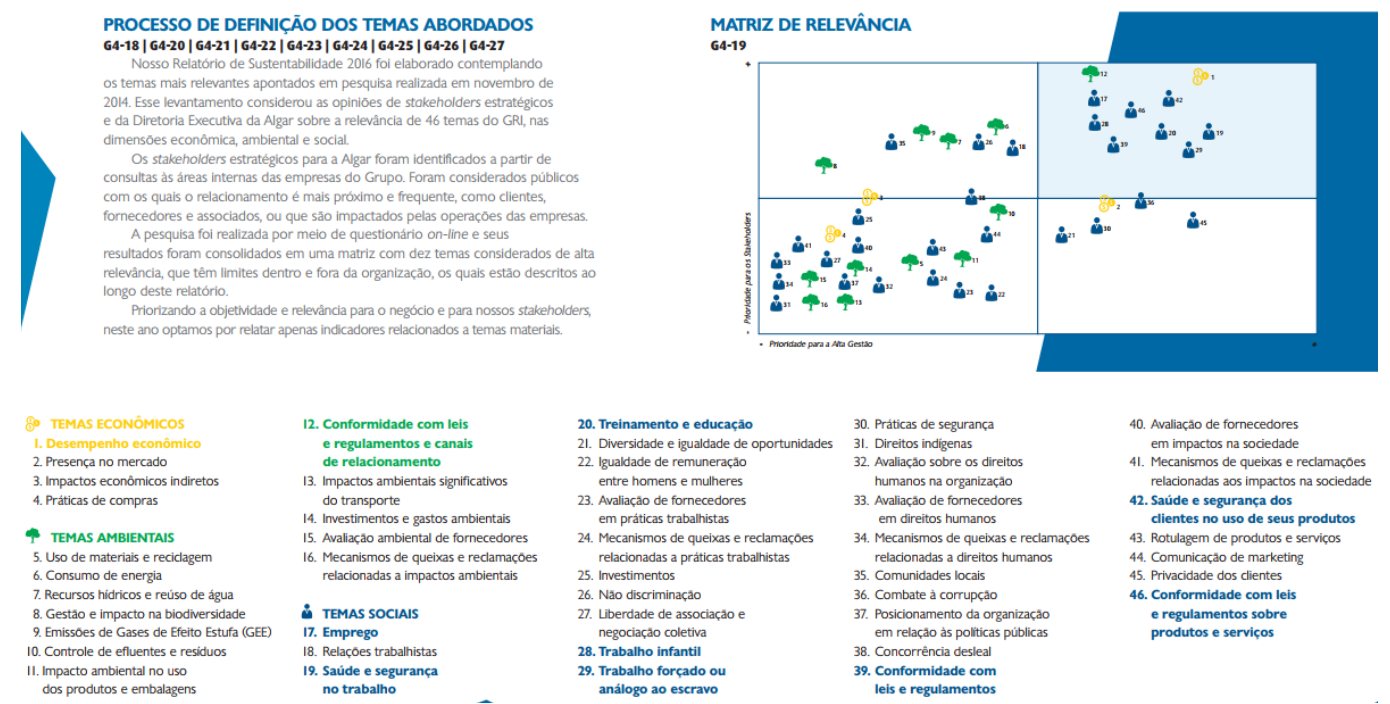

3.1 Na sua opinião, que fatos ou fatores levaram a essas duas concentrações?

3.2 Você considera oportuno rebalancear os temas relevantes? (em termos das três dimensões da sustentabilidade? e/ou de maior representatividade de outros temas estratégicos, além da conformidade a leis, normas e regulamentos?)

\section{PARTE 2: PERCEPÇÃO SISTÊMICA MULTISSETORIAL}

4. Considerando que a percepção sistêmica multissetorial pressupõe a análise do desempenho em sustentabilidade das empresas do Grupo Algar em seus respectivos setores (TIC, agro, serviços e turismo), você considera que a multissetorialidade 
poderia ser melhor 'comunicada' nos próximos Relatórios de Sustentabilidade do Grupo?

4.1 Considera oportuna a análise de relevância dos aspectos materiais por grupo de stakeholders de diferentes contextos socioprodutivos (TIC, agroindústria, serviços e turismo)? Por exemplo, gerando-se inicialmente quatro matrizes de materialidade (uma por setor) para depois consolidar a matriz corporativa?

4.2 Considera relevante que a escolha de indicadores GRI seja feita inicialmente por setor, correspondendo aos respectivos aspectos materiais de cada uma das quatro matrizes de relevância?

4.3 Outras sugestões de melhoria para a comunicação da multissetorialidade?

\section{PARTE 3: DIFICULDADES NA ELABORAÇÃO DOS RELATÓRIOS}

5. Nos seis anos de publicação dos Relatórios de Sustentabilidade do Grupo Algar, que dificuldades foram observadas no processo de elaboração desses documentos, pelo fato do Grupo Algar ser multissetorial e não dispor de Diretrizes GRI G4 específicas para grupos multissetoriais? Como os problemas vêm sendo equacionados?

6. Na análise das Diretrizes GRI G4, identificou-se a existência de diretrizes setoriais apenas para o setor 'agro', sob o título "food processing" na versão em inglês. Essas diretrizes setoriais vêm sendo utilizadas na elaboração dos Relatórios de Sustentabilidade do setor agro? Em caso afirmativo, elas têm sido consideradas também na elaboração do Relatório em nível multissetorial (visão corporativa)?

7. Para os setores TIC, serviços e turismo, o Grupo Algar considera outros referenciais normativos específicos para esses setores, além das Diretrizes GRI G4? Em caso afirmativo, quais referenciais são usados? Por exemplo, para o setor turismo utiliza o guia "Indicators of Sustainable Development for Tourism Destinations: a Guidebook", publicado pela Organização Mundial de Turismo?

\section{PARTE 4: BENEFÍCIOS ESPERADOS COM O MODELO}

8. Que benefícios potenciais você espera de um modelo de monitoramento e avaliação de desempenho em sustentabilidade de grupos multissetoriais, que contenha diretrizes específicas para grupos multissetoriais no nível corporativo?

\section{Síntese dos resultados das entrevistas}

\section{PARTE 1: MATRIZ DE MATERIALIDADE}

1. Você considera que o processo de escolha dos aspectos materiais de maior relevância para o Grupo Algar e seus stakeholders poderia ser melhorado, em função do Grupo ser multissetorial e atuar em diversos contextos socioprodutivos, com diferentes stakeholders em cada um desses contextos?

Síntese: Identificação dos impactos e limites: o processo deve considerar 'o que importa? e onde importa? - parte-se de uma lista ampla de temas potencialmente 
relevantes e identificando para cada um deles onde ocorrem os impactos dentro e fora da organização. Por meio do relatório de sustentabilidade da Algar, não está claro se essa avaliação foi realizada. O indicador G4-20, de inclusão obrigatória, deveria informar os limites de cada aspecto, incluindo as entidades incluídas no relatório para as quais o aspecto é material ou não.

Engajamento stakeholders: Não há uma listagem dos stakeholders (G4-24) para que se possa avaliar quais foram engajados na análise de materialidade - e se foram compreendidos stakeholders de todas as empresas do Grupo.

Priorização dos temas: a priorização dos temas levantados deveria considerar: i) a significância de seus impactos econômicos, sociais e ambientais; e, ii) sua influência sobre as avaliações e decisões dos stakeholders. A matriz de relevância apresentada no relatório de sustentabilidade da Algar é composta por Prioridade para os stakeholders vs. Prioridade para alta direção. Não está claro os motivos pelos quais os temas são prioritários, se foram considerados os potenciais impactos nos diversos setores de atuação e sobre os multistakeholders do Grupo.

Geral: Há uma percepção dos entrevistados que as empresas do Grupo Algar, atuantes nos diversos setores que o Grupo participa, poderiam ter representantes mais ativos nos processos relacionados aos stakeholders, construção da matriz de materialidade e, principalmente, no macroprocesso relacionado à construção do Relatório da Sustentabilidade / Os processos podem ter mais cuidado nos momentos críticos priorizando atividades presenciais / O Grupo Algar possui empresas com características diferentes, com realidades diversas / A Algar Telecom (setor: Telecomunicações) realiza um processo único e centralizado / Há uma ação chamada 'kick-off' que envolve todos os representantes das empresas do Grupo no início do processo de elaboração anual do Relatório da Sustentabilidade / Dificuldade de consolidação sempre foi um desafio / Listas dos stakeholders devem ser diferenciadas para as empresas / Diretrizes estratégicas individuais de cada empresa desdobram-se em metas e objetivos específicos.

Complementos mais relevantes obtidos nas entrevistas: Em 2008, $1^{\circ}$ relatório de emissões de GEE. Diagnóstico 2017: FDC (Fundação Dom Cabral), utilizam outras 2 empresas Eco Universo e ICF International; Algar Telecom e Algar Agro fizeram processos separados das demais empresas do Grupo (não se limitaram ao estudo que a Holding apresentou). Questionário qualitativo utilizado é de 2015. Consideram como principais stakeholders: Bancos, governos, clientes, associados e fornecedores;

2. Em caso afirmativo, que melhorias você sugere? Uso de ferramentas multicritério de apoio à decisão? Análise de estudos setoriais? Alinhamento a referenciais de sustentabilidade para setores em que o Grupo Algar atua?

Síntese: O ideal seria partir de uma lista ampla de aspectos materiais relevantes, considerando a diversidade de operações do Grupo. A lista inicial de aspectos materiais relevantes poderia contemplar os aspectos da GRI Standards, das Diretrizes setoriais específicas, outras pesquisas oficiais ou referências reconhecidas. As referências setoriais podem ser úteis na identificação dos impactos e limites. Considerando a diversidade e dinâmica das operações, o engajamento dos stakeholders deve ser abrangente e contínuo, buscando revisar e aperfeiçoar a matriz de materialidade periodicamente.

Complementos mais relevantes obtidos nas entrevistas: $\mathrm{O}$ processo do planejamento estratégico não se relaciona com as Diretrizes GRI / O Relatório da 
Sustentabilidade deve ser uma publicação dinâmica e utilizável ao longo do ano / Temas materiais separados por setor e/ou empresas / Fundamental transmitir com bastante clareza os objetivos corporativos para as operações / O foco hoje é muito voltado para o relato de realizações passadas, deve-se olhar para o futuro com relacionamento com visão estratégica, utilização dos indicadores como referência nas tomadas de decisão.

3. Em uma primeira análise da "Matriz de Materialidade" constante do Relatório de Sustentabilidade - 2016, observou-se dentre os dez aspectos materiais situados no quadrante superior direito, sete são associados a atendimento a leis, regulamentos e normas. Um segundo aspecto que chamou atenção é a ênfase em temas sociais (oito dos dez temas mais relevantes).

3.1 $\mathrm{Na}$ sua opinião, que fatos ou fatores levaram a essas duas concentrações?

3.2 Você considera oportuno rebalancear os aspectos materiais relevantes? (em termos das três dimensões da sustentabilidade? e/ou de maior representatividade de outros aspectos materiais, além da conformidade a leis, normas e regulamentos?)

Síntese: O processo de engajamento de stakeholders tem por objetivo também identificar os aspectos importantes para os principais atores envolvidos e reconhecer as lacunas entre as percepções da organização e dos stakeholders. Se olharmos para o quadrante superior esquerdo do gráfico, notamos que a maioria dos aspectos considerados importantes para os stakeholders têm cunho ambiental, enquanto que para a alta direção apenas a conformidade com leis ambientais foi considerada material. Em 2016 foi realizado um levantamento sobre temas potencialmente materiais para cada setor em que a Algar atua com base em um estudo da GRI 'Sustainability Topics for Sectors' (2013). Este estudo compreendeu diversas empresas no mundo todo e multistakeholders. Por meio do levantamento, só no quesito ambiental, 8 temas foram identificados como relevantes para setores em que o Grupo atua, frente a apenas 1 resultante da materialidade realizada pela Algar em 2014. A discrepância entre esses resultados ocorre por diversos fatores; como se deu o processo de escolha dos temas materiais em si, maturidade da governança ambiental nas empresas da Algar ou do mercado local, diferenças no rigor de regulações sobre as quais as empresas estão submetidas, etc. (deixo aqui uma brecha para que vocês opinem sobre esse resultado). Por ser um grupo familiar com mercado local, as cobranças hoje podem ser menores, mas entendendo o resultado do estudo como uma perspectiva global, há uma tendência de governança mais ampla, além da conformidade com leis. Com relação ao balanceamento dos aspectos materiais relevantes, essa é uma orientação da própria diretriz da GRI. Após a priorização de temas os mesmos devem ser validados para garantir que o relatório ofereça uma representação equilibrada e sensata do desempenho da organização, incluindo impactos positivos e negativos.

Complementos mais relevantes obtidos nas entrevistas: Há uma preocupação com a relação 'esforço x retorno' em relação ao processo de elaboração da matriz de materialidade como um todo, relacionado ao capital financeiro e humano alocado em todas as etapas / A concentração de aspectos materiais relacionados a categoria 'social' da sustentabilidade tem relação com diretrizes informadas pelo Instituto Algar / A concentração dos aspectos materiais na categoria 'social' não reflete preocupações e esforços com as categorias 'econômica' e 'ambiental' da sustentabilidade / Fiscalizações trabalhistas são mais constantes em empresas com mão de obra mais numerosa e isso explica 
parcialmente essa concentração / Projetos ambientais relevantes não estão refletidos I A matriz reflete obrigações e não os diferenciais de esforços importantes realizados pelo Grupo / Exigências relacionadas ao 'Compliance' e ao cumprimento de legislações.

\section{PARTE 2: PERCEPÇÃO SISTÊMICA MULTISSETORIAL}

4. Considera oportuna a análise de relevância dos aspectos materiais por grupo de stakeholders de diferentes contextos socioprodutivos (TIC, agroindústria, serviços e turismo)? Por exemplo, gerando-se inicialmente quatro matrizes de materialidade (uma por setor) para depois consolidar a matriz corporativa?

4.1 Considera relevante que a escolha de indicadores GRI seja feita inicialmente por setor, correspondendo aos respectivos aspectos materiais de cada uma das quatro matrizes de relevância?

4.2 Outras sugestões de melhoria para a comunicação da multissetorialidade?

Síntese: Pode ser um caminho. Entretanto, ao dar peso aos setores pode-se deixar de lado um tema muito relevante (de grande impacto, por exemplo) em apenas um setor ou "obrigar" um determinado setor a reportar um tema de não tanta importância para seus stakeholders. Importante a multissetorialidade (empresas e respectivos setores) e a matriz final considere os limites de cada aspecto.

Os indicadores devem ser os que melhor traduzem os tópicos que os stakeholders querem conhecer. Pode ser que seja necessário um ou vários indicadores para cada tópico ou pode ser que na GRI não exista um indicador que represente de forma fidedigna do que os stakeholders querem saber. Nesse caso, a empresa pode criar uma métrica própria para relatar tal tópico. Acho que a principal melhoria está no planejamento, no engajamento dos stakeholders, na avaliação das diferentes percepções e entendimento dos pontos a serem melhorados na governança das empresas (uma vez que o processo como um todo não tem a intenção apenas de comunicar).

Complementos mais relevantes obtidos nas entrevistas: Dentro dos aspectos comunicados, resultantes da materialidade realizada em 2014, a análise do desempenho é feita por empresa. Porém, tratando-se de um Grupo com atividades tão distintas, é natural que as empresas não se sobressaiam da mesma forma quando compilados os dados do Grupo uma vez que a significância dos impactos e influência na decisão dos stakeholders não será igual para todos os negócios. Vale ressaltar que, apesar da materialidade ter resultado em apenas um tópico ambiental material, é feito o acompanhamento de pelo menos cinco outros para cada empresa. Os indicadores acompanhados periodicamente foram escolhidos com base no estudo de benchmarking mencionado acima, nas ações existentes nas empresas (como mensurá-las?) e feedback do comitê ambiental das empresas / Perspectivas estratégicas podem estar melhor representadas.

\section{PARTE 3: DIFICULDADES NA ELABORAÇÃO DOS RELATÓRIOS}

5. Nos seis anos de publicação dos Relatórios de Sustentabilidade do Grupo Algar, que dificuldades foram observadas no processo de elaboração desses documentos, pelo fato do Grupo Algar ser multissetorial e não dispor de Diretrizes GRI G4 
específicas para grupos multissetoriais? Como os problemas vêm sendo equacionados?

6. Na análise das Diretrizes GRI G4, identificou-se a existência de diretrizes setoriais apenas para o setor 'agro', sob o título "food processing" na versão em inglês. Essas diretrizes setoriais vêm sendo utilizadas na elaboração dos Relatórios de Sustentabilidade do setor agro? Em caso afirmativo, elas têm sido consideradas também na elaboração do Relatório em nível multissetorial (visão corporativa)?

7. Para os setores TIC, serviços e turismo, o Grupo Algar considera outros referenciais normativos específicos para esses setores, além das Diretrizes GRI G4? Em caso afirmativo, quais referenciais são usados? Por exemplo, para o setor turismo utiliza o Guia "Indicators of Sustainable Development for Tourism Destinations: a Guidebook”, publicado pela Organização Mundial de Turismo?

Síntese: Dificuldade por ser um grupo multissetorial acredita-se que não houve. Os representantes da GRI no Brasil já esclareceram diversas vezes que as Diretrizes não constituem regras. Elas têm o objetivo de orientar. No Grupo Algar, a área responsável busca interpretar seu conteúdo da melhor forma, observando também referências de outros grupos empresariais. O uso das Diretrizes setoriais é recomendado na ocasião da identificação de temas materiais. Quanto ao seu uso na elaboração do documento, o Instituto Algar responde pelos aspectos materiais relacionados a categoria ambiental.

Para elaboração dos relatórios da Algar Telecom e Alagar Agro, utilizam-se ocasionalmente relatórios de outras organizações com atividades similares, concorrentes como o Grupo Jales Machado (açúcar e álcool). Isto de maneira não sistematizada. As empresas do gruo Algar relacionadas ao setor agronegócios olham para GHG Protocol, UTZ, Pegada de Carbono, SE8000, PEA (Programa de Educação Ambiental), AMAGGI.

Complementos relevantes obtidos nas entrevistas: Há setores/empresas que os representantes da sustentabilidade não tem dedicações exclusiva, há um compartilhamento do tempo com diversas outras atividades / "Desnivelamento" entre as empresas do grupo, dificuldade na mensurabilidade / O Instituto Algar faz acompanhamento periódico dos indicadores ambientais, criticando-os para garantir sua consistência, e realiza, trimestralmente, reuniões com todos os comitês ambientais das empresas visando orientar e ouvir as demandas individuais de cada uma delas / Custos e esforços relacionados à elaboração do Relatório da Sustentabilidade são considerados elevados. Não há utilização direta de Diretrizes setoriais ou outras na elaboração do Relatório da Sustentabilidade Corporativo do Grupo Algar. Há uma consciência que o Grupo Algar pode contribuir para o cumprimento das metas de redução de emissões para o Brasil para 2025 e 2030 / Adesão ao Pacto Global.

\section{PARTE 4: BENEFÍCIOS ESPERADOS COM O MODELO}

8. Que benefícios potenciais você espera de um modelo de monitoramento e avaliação de desempenho em sustentabilidade de grupos multissetoriais, que contenha diretrizes específicas para grupos multissetoriais no nível corporativo?

Síntese: A área da sustentabilidade declarou acreditar que as Diretrizes GRI já 
forneçam informações suficientes para elaboração de relatórios de grupos multissetoriais, talvez possa trazer um pouco mais de clareza ou exemplos que ilustrem como a diretriz genérica, possa ser aplicada por grupos com diferentes atividades. Quanto às diretrizes setoriais, acredita que auxiliem as empresas a identificar tópicos que possam ser relevantes para seu setor, além dos genéricos já trazidos pela diretriz "mãe". Hoje na prática o Grupo Algar poderia estar assim apresentado/subdividido: Telecom, Tech, Agro, Farming, Segurança, Unialgar, Alsol, Rio Quente Resorts, Holding (inclui Instituto Algar) e CSC (Centro de Soluções Compartilhadas) / Hoje há comitês ambiental (liderado pelo Instituto Algar) e social (voluntários de cada empresa) / O site da Algar pode estar mais atualizado que o relatório de sustentabilidade, por exemplo, na apresentação da estrutura multissetorial do Grupo Algar.

Complementos relevantes obtidos nas entrevistas: Desejo de relacionamento da parte estratégica com o Relatório da Sustentabilidade / Gestão do portfólio é um desafio / A multissetorialidade é um dos maiores desafios em termos de interpretação de resultados e direcionamentos estratégicos (objetivos, metas - mapa estratégico) / Inovação e apelo ambiental podem ser melhor declarados / Hierarquização de temas em termos de suas importâncias / Avaliação em conjunto da compreensão e disseminação das prioridades estratégicas / Importância da integração em termos estratégicos dos esforços relacionados a construção do Relatório da Sustentabilidade / Melhor cobertura dos resultados e esforços setoriais / Melhor compreensão da multissetorialidade do Grupo Algar / Ter o Relatório da Sustentabilidade como uma pilar para condução estratégica sustentável. 


\section{Apêndice 3 - Agendas das reuniões com o Grupo Algar para aplicação do modelo proposto}

Neste apêndice 3, apresentam-se as agendas das reuniões conduzidas pelo pesquisador e sua orientadora para aplicação do modelo proposto no contexto corporativo do Grupo Algar, durante o período de 07 a 09 de março de 2018.

\section{Agenda 1: Sustentabilidade}

Data e horário: 07/03/2018 das 14h30 às $17 \mathrm{~h} 30$

Participantes:

\section{Eliane Garcia Melgaço (VP Gente)}

Luciana Vasconcelos (Sustentabilidade)

Carolina Toffoli (Instituto Algar)

Thiago Frank (Instituto Algar).

\section{Agenda 2: Nível Setorial}

Data e horário: 08/03/2018 das 9h00 às $12 \mathrm{~h} 00$

Participantes:

Cristiana Heluy (Algar Telecom)

Thiago Frank (Instituto Algar).

\section{Agenda 3: Corporativo Multissetorial}

Data e horário: 09/03/2018 das 9h00 às $12 \mathrm{~h} 00$

Participantes:

Luiz Alexandre Garcia (CEO)

Luciana Vasconcelos (VP Finanças e Responsável pelo Relatório da

Sustentabilidade)

Cristiana Heluy (Algar Telecom)

Estela Lisboa (Algar Tech)

Neide Aparecida Gonçalves (Rio Quente Resorts)

Rodrigo Latuf (Alsol)

Carolina Toffoli (Instituto Algar)

Thiago Frank (Instituto Algar). 